\title{
EFEITO DO CORTE RASO NO BALANÇO HÍDRICO E NA CICLAGEM DE NUTRIENTES EM UMA MICROBACIA REFLORESTADA COM EUCALIPTO
}

\author{
ANA ROSA TUUNDIS VITAL \\ Tecnólogo
}

Orientador: Prof. Dr. Walter de Paula Lima

Dissertação apresentada à Escola Superior de Agricultura "Luiz de Queiroz", da Universidade de São Paulo, para obtenção de título de Mestre em Ciências, Área de Concentração: Ciências Florestais.

\author{
P I R A C I C A B A \\ Estado de São Paulo - Brasil \\ Novembro - 1996
}




\title{
Dados Internacionais de Catalogação na Publicação (CIP) DIVISĀO DE BIBLIOTECA E DOCUMENTAÇĀO - Campus “Luiz de Queiroz"/uSP
}

\author{
Vital, Ana Rosa Tundis \\ Efeito do corte raso no balanço hidrico e na ciclagem de nutrientes em uma microbacia \\ reflorestada com eucalipto / Ana Rosa Tundis Vital. - Piracicaba , 1996. \\ 106p. : it. \\ Dissertação (mestrado) - Escola Superior de Agricultura Luiz de Queiroz, 1996. \\ Bibliografia. \\ 1. Eucalipto - Corte - Efeito 2. Microbacia - Balanço hídrico 3. Microbacia - Ciclo de \\ nutriente 4. Reflorestamento 1. Título \\ CDD 551.483 \\ 634.9734
}




\section{EFEITO DO CORTE RASO NO BALANÇO HÍDRICO E NA CICLAGEM DE NUTRIENTES EM UMA MICROBACIA REFLORESTADA COM EUCALIPTO}

ANA ROSA TUNDIS VITAL

Aprovada em 06.12.1996

Comissão julgadora:

Prof. Dr. Walter de Paula Lima

Prof. Dr. Fábio Poggiani

Prof. Dr. Paulo Leonel Libardi
ESALQ/USP ESALQ/USP ESALQ/USP.

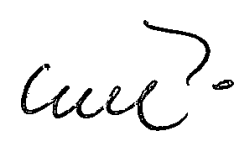

Prof. Dr. WALTER DE PAULA LIMA Orientador 


\section{- Aos meus Pais Osmar e Filomena, aos meus irmãos Simão Pedro, Joaquina e João Silvério, as sobrinhas Catherine e Simone, Ao Walter Humberto.}




\section{AGRADECIMENTOS}

Esta dissertação não é o esforço e dedicação de uma só pessoa, também é o resultado da colaboração de inúmeras pessoas para às quais expresso os mais sinceros agradecimentos.

Ao orientador Prof. Dr. Walter de Paula Lima, pela amizade, paciência e orientação efetiva para elaboração deste trabalho.

Ao Departamento de Ciências Florestais e Instituto de Pesquisa e Estudos Florestais, que proporcionaram o andamento desta pesquisa.

À Votorantim Celulose e Papel S/A., na pessoa do Eng. Florestal Fausto Rodrigues Alves de Camargo, pelo apoio material e de recursos humanos, representado pelo trabalho eficiente do Técnico de Pesquisa Luiz Carlos da Silva (Guerreiro).

Ao Prof. Dr. Fabio Poggiani, meu reconhecimento pelas suas importantes e valiosas sugestões, sempre que necessário, e coorientação.

Ao Professor José Luiz Stape pelo seu importante assessoramento estatístico.

À técnica de laboratório Alba Valério Masetto, pela amizade, consideração e ajuda nas análises de laboratório.

Aos colegas da Pós - graduação, pelo companheirismo e apoio durante o decorrer do curso.

Aos colegas Leila, André, Edson e Erika que colaboraram nas diferentes fases deste estudo.

À Maria de Fátima Dürrer Juliani, secretária do Departamento de Ciências Florestais, assim como as funcionárias $\mathrm{M}^{\mathrm{a}}$ Regina Buch, Margarete Aparecida Z. Pinese e Marialice Metzker Poggiani, pela atenção e contribuição prestada.

Enfim expresso meu profundo agradecimento a todos àqueles que de uma forma ou de outra contribuiram para que este trabalho se tornasse possível. 


\section{SUMÁRIO}

LISTA DE FIGURAS

Página

LISTA DE TABELAS

vi

LISTA DE APÊNDICES

vii

RESUMO

viii

ABSTRACT

ix

xii

1. Introdução.

2. Revisão de Literatura.

2.1. Processos hidrológicos em microbacias

2.2. Produção de fitomassa e acúmulo de nutrientes em plantações florestais

2.3. Impactos da exploração florestal..

3. Material.

3.1. Área experimental

3.1.1. Localização.

3.1.2. Clima

3.1.3. Geologia e Geomorfologia

3.1.4. Solos 28

3.1.5. Vegetação . 29

3.2. Métodos.

30

3.2.1. Fluviometria e pluviometria .............................................. 30

3.2.2. Parâmetros físicos e químicos .............................................. 33

3.2.3. Sedimentometria .............................................................. 35

3.2.4. Estimativa da fitomassa e da mineralomassa da parte aérea das árvores .

3.2.4.1. Escolha e corte das árvores representativas.

3.2.4.2. Determinação da massa seca das árvores amostrais...

3.2.4.3. Determinação da concentração de nutrientes nos diferentes compartimentos das árvores.

3.2.4.4. Determinação das equações para estimativa da biomassa arbórea

3.2.4.4.1.Estimativa da fitomassa arbórea acima do solo e da mineralomassa.

4. Resultados e Discussão.

4.1. Aspectos Hidrológicos ............................................................ 45

4.1.1. Balanço hídrico............................................................... 45

4.2. Qualidade da água ............................................................... 51

4.2.1. Parâmetros químicos ..................................................... 51 
4.2.2. Parâmetros físicos........................................................... 56

4.3. Balanço de Nutrientes .............................................................. 63

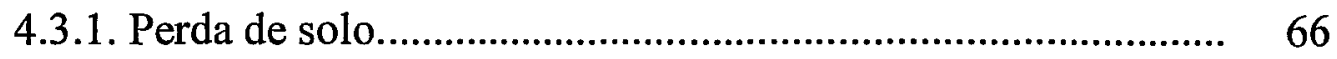

4.4. Fitomassa arbórea e mineralomassa da parte aérea da plantação florestal da microbacia A............................................................... $\quad 69$

4.4.1. Fitomassa nos diferentes compartimentos das árvores.......... 69

4.4.2. Concentração de nutrientes nos diferentes compartimentos das árvores. ..................................................................... 70

4.4.3. Conteúdo de nutrientes na fitomassa arbórea ........................ 74

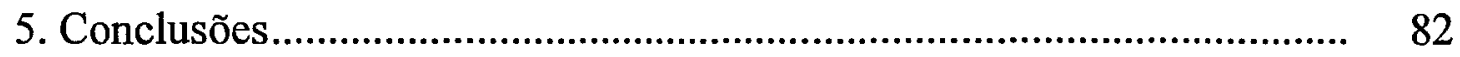

6. Recomendações .......................................................................... 84

Referências Bibliográficas................................................................. 86

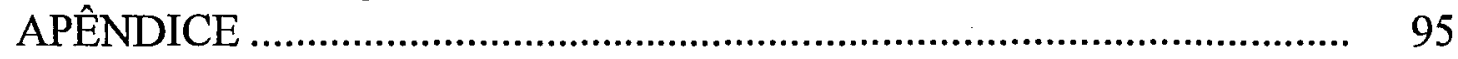




\section{LISTA DE FIGURAS}

Página

Figura 1. Mapa da localização da área experimental

27

Figura 2. Estação fluviométrica com vertedor triangular de $90^{\circ}$.............. 32

Figura 3. Estação fluviométrica com linígrafo modelo hidrologia ........... 32

Figura 4. Mapa da área experimental ................................................... 36

Figura 5. Plantação florestal de Eucalyptus saligna aos 7 anos ............... 41

Figura 6. Vista da microbacia A após o corte ......................................... 42

Figura 7. Valores médios anuais de deflúvio na microbacia A (Período: junho de 1987 a maio de 1995 ................................................ 46

Figura 8. Representação esquemática do balanço hídrico para a microbacia A e B (Período: junho de 1987 a maio de 1995).....

Figura 9. Variação mensal do $\mathrm{Ph}$ nos deflúvios das microbacias A e B (Período: junho de 1987 a maio de 1995)

Figura 10. Variação mensal da Alcalinidade nos deflúvios das microbacias A e B (Período: junho de 1987 a maio de 1995) ...

Figura 11. Variação mensal da Condutividade elétrica na água da precipitação e do deflúvio das microbacias A e B (Período: junho de 1987 a maio de 1995).

Figura 12. Variação mensal da Cor na água da precipitação e do deflúvio das microbacias A e B (Período: junho de 1987 a maio de 1995)

Figura 13. Variação mensal da Turbidez na água da precipitação e do deflúvio das microbacias A e B (Período: junho de 1987 a maio de 1995)

Figura 14. Média anual da perda de sedimento em suspensão (kg.ha ${ }^{1}$.ano ${ }^{-1}$.) na água das microbacias A e B (Período: junho de 1987 a maio de 1995)

Figura 15. Balanço geoquímico de nutrientes $\left(\mathrm{Kg}_{\mathrm{h}} \mathrm{ha}^{-1} \mathrm{ano}^{-1}\right.$ ) (Período: junho de 1987 a maio de 1995)

Figura 16. Valores totais para o balanço de nutrientes $\left(\mathrm{Kg} \mathrm{ha}^{-1} \cdot \mathrm{ano}^{-1}\right)$ (Período: junho de 1987 a maio de 1995). 


\section{LISTA DE TABELAS}

Tabela 1. Balanço hídrico comparativo de microbacias contendo diferentes coberturas vegetais.

Tabela 2. Concentrações médias mensais de $\mathrm{NO}_{3}{ }^{-}, \mathrm{K}^{+}, \mathrm{Ca}^{++}, \mathrm{Mg}^{++}, \mathrm{Fe}^{++}$, e $\mathrm{Na}^{+}$na água da chuva e na água do deflúvio da microbacia $\mathrm{A}$ e microbacia B (Período: junho de 1987 a maio de 1994).

Tabela 3. Concentrações médias mensais de $\mathrm{NO}_{3}^{-}, \mathrm{K}^{+}, \mathrm{Ca}^{++}, \mathrm{Mg}^{++}, \mathrm{Fe}^{++}$, e $\mathrm{Na}^{+}$, na água da chuva e na água do deflúvio da microbacia A (Período: junho de 1994 a maio de 1995)

Tabela 4. Valores médios anuais da densidade de fluxo $\left(\mathrm{Kg}_{\mathrm{ha}} \mathrm{C}^{-1}\right.$. ano $\left.{ }^{-1}\right)$ para os nutrientes $\mathrm{NO}_{3}^{-}, \mathrm{K}^{+}, \mathrm{Ca}^{++}, \mathrm{Mg}^{++}, \mathrm{Fe}^{++}$, e Na ${ }^{+}$na água da chuva e na água do deflúvio da microbacia A (Período: junho de 1987 a maio de 1994).

Tabela 5. Valores médios anuais da densidade de fluxo $\left(\mathrm{Kg}_{\mathrm{ha}} \mathrm{h}^{-1} \cdot \mathrm{ano}^{-1}\right)$ para os nutrientes $\mathrm{NO}_{3}^{-}, \mathrm{K}^{+}, \mathrm{Ca}^{++}, \mathrm{Mg}^{++}, \mathrm{Fe}^{++}$, e $\mathrm{Na}^{+}$, determinado pela entrada via água da chuva e saída via deflúvio da microbacia A e microbacia $\mathrm{B}$ (Período: junho de 1994 a maio de 1995)

Tabela 6. Balanço médio anual $\left(\mathrm{kg} \mathrm{ha}^{-1}\right)$ de $\mathrm{NO}_{3}^{-}, \mathrm{K}^{+}, \mathrm{Ca}^{++}, \mathrm{Mg}^{++}, \mathrm{Fe}^{++}$, e $\mathrm{Na}^{+}$, determinado pela entrada via água da chuva e saída via deflúvio da microbacia A (Período: junho de 1987 a maio de 1994)

Tabela 7. Balanço médio anual $\left(\mathrm{kg}^{-h a^{-1}}\right)$ de $\mathrm{NO}_{3}^{-}, \mathrm{K}^{+}, \mathrm{Ca}^{++}, \mathrm{Mg}^{++}, \mathrm{Fe}^{++}$, e $\mathrm{Na}^{+}$, determinado pela entrada via água da chuva e saída via deflúvio da microbacia A (Período: junho de 1994 a maio de 1995)

Tabela 8. Valores dendrométricos do reflorestamento com Eucalyptus saligna aos 7 anos de idade.

Tabela 9. Fitomassa seca $\left(\mathrm{Kg}_{\mathrm{gha}}{ }^{-1}\right)$ e (\%) do total em plantação de Eucalyptus saligna aos 7 anos

Tabela 10. Concentração de nutrientes nos diferentes componentes das árvores de Eucalyptus saligna aos 7 anos de idade

Tabela 11. Fitomassa arbórea e nutrientes estocados $\left(\mathrm{Kg}^{-h^{-1}}{ }^{-1}\right)$ nos diferentes componentes de Eucalyptus saligna e suas respectivas porcentagens do peso total 


\section{LISTA DE APÊNDICES}

Página

1. Análise do solo da microbacia A ...................................................... 95

2. Análise do solo da microbacia B..................................................... 99

3. Precipitação anual (mm) para as microbacias A e B. (Período: jun/87 a $\mathrm{mai} / 95)$

4. Deflúvio (mm) para as microbacias A e B. (Período: jun/87 a mai/95) . 104

5. Média anual para os Parâmetros físicos $\mathrm{pH}$, alcalinidade, condutividade, cor e turbidez na precipitação (Prec.) e defluvio das microbacias A (DFA) e B (DFB) para o período: (jun/87 a mai/94)..... 105

6. Média anual para os Parâmetros físicos $\mathrm{pH}$, alcalinidade, condutividade, cor e turbidez na precipitação (Prec.) e defluvio da microbacia A (DFA) para o período: (jun/87 a mai/95) ...................... 106 


\title{
EFEITO DO CORTE RASO NO BALANÇO HÍDRICO E NA CICLAGEM DE NUTRIENTES EM UMA MICROBACIA REFLORESTADA COM EUCALIPTO
}

\author{
Autor: ANA ROSA TUNDIS VITAL \\ Orientador: Prof. Dr. WALTER DE PAULA LIMA
}

\section{RESUMO}

Neste trabalho estudou-se o balanço hídrico em duas microbacias adjacentes reflorestadas com Eucalyptus saligna Smith. e o efeito do corte raso no balanço hídrico, qualidade química e parâmetros físicos da água, ciclagem de nutrientes, perdas de solo e quantidade de nutrientes minerais exportados com a biomassa lenhosa após o tratamento em uma das microbacias.

As microbacias experimentais localizam-se no Vale do Paraíba, Fazenda Bela Vista III, pertencente à Votorantim Celulose e Papel S/A, entre as coordenadas $25^{\circ} 25^{\prime}$ de latitude sul e $45^{\circ} 54^{\prime}$ de longitude a oeste de Greenwich com altitude média de $695 \mathrm{~m}$, Município de Santa Branca, Estado de São Paulo, onde o clima é do tipo Cwa, segundo a classificação de Köeppen, caracterizado como temperado de inverno seco, onde a precipitação média anual é de $1.562 \mathrm{~mm}$.

Na região predomina o solo podzólico Vermelho amarelo álico $\mathrm{Tb} \mathrm{A}$ moderado e textura média argilosa.

A microbacia A possui uma área de 7,0 ha, sendo $3,3 \%$ da área de mata ciliar, com uma declividade média de $19,6 \%$; a área da microbacia $\mathrm{B}$ é de 6,5 ha, com $2,1 \%$ da área de mata ciliar e declividade média de $28,9 \%$.

O período experimental total foi de oito anos, tendo a comparação sido feita entre os dados dos sete primeiros anos antes do corte raso da plantação de eucalipto, aos sete anos de idade, com os obtidos durante o primeiro ano após o corte. A microbacia B permaneceu com a plantação de eucalipto inalterada.

Além da precipitação e da vazão, foram obtidas durante o período experimental amostras da água da chuva e do deflúvio, para fins de análises da qualidade da água e quantificação da ciclagem geoquímica de nutrientes $\mathrm{NO}_{3}^{-}, \mathrm{K}^{+}, \mathrm{Ca}^{++}, \mathrm{Mg}^{++}, \mathrm{Fe}^{++}$e $\mathrm{Na}^{+}$. 
A quantidade de nutrientes exportados com a biomassa lenhosa foi obtida apartir da estimativa da biomassa arbórea e do conteúdo de nutrientes (fitomassa e mineralomassa, respectivamente) da parte aérea das árvores.

Para os oito anos do período experimental, em termos médios, o balanço hídrico para as duas microbacias mostrou os seguintes valores:

\section{Microbacia A:}

Antes do corte (média de 7 anos): Precipitação: 1329mm

$$
\text { Deflúvio: } 145 \mathrm{~mm}
$$

Depois do corte: (1 ano) : Precipitação: $1321 \mathrm{~mm}$

Deflúvio: $115 \mathrm{~mm}$

\section{Microbacia B:}

Média de 7 anos: Precipitação: 1329mm

Deflúvio: $201 \mathrm{~mm}$

A evapotranspiração média anual para o período experimental foi de: $1186 \mathrm{~mm}$ para microbacia $\mathrm{A}$, representando $89,3 \%$ de precipitação média anual e $1129 \mathrm{~mm}$ para microbacia $\mathrm{B}$, representando $84,9 \%$ da precipitação média anual (antes do corte); e 1205 para microbacia A, representando 91,3\% da precipitação média anual (pós-corte).

A diferença entre a entrada de nutrientes pela água da chuva e perda através do deflúvio apresentou os seguintes resultados, em termos médios anuais, para o balanço geoquímico em kg.ha ${ }^{-1} \cdot$ ano $^{-1}: \mathrm{NO}_{3}^{-} 8,81 ; \mathrm{K}^{+} 0,91 ; \mathrm{Ca}^{++}$ 1,$47 ; \mathrm{Mg}^{++} 0,37 ; \mathrm{Fe}^{++}-1,91 ; \mathrm{Na}^{+} 1,69$ para a microbacia $\mathrm{A} \mathrm{e} \mathrm{NO}_{3}^{-} 8,44 ; \mathrm{K}^{+} 2,75$; $\mathrm{Ca}^{++} 2,04 ; \mathrm{Mg}^{++}-0,16 ; \mathrm{Fe}^{++} 0,06 ; \mathrm{Na}^{+} 0,33$ para microbacia $\mathrm{B}$ (antes do corte) e $\mathrm{NO}_{3}^{-} 8,19 ; \mathrm{K}^{+} 1,14 ; \mathrm{Ca}^{++} 4,47 ; \mathrm{Mg}^{++} 1,70 ; \mathrm{Fe}^{++}-4,63 \mathrm{e} \mathrm{Na}^{+} 1,92$ para microbacia A (pós-corte).

Os parâmetros físicos condutividade, cor e turbidez apresentaram alta variabilidade para ambas as bacias; já o $\mathrm{pH}$ e a condutividade elétrica mostraran-se praticamente inalterados durante os sete primeiros anos, sendo que na microbacia $A$, estes parâmetros foram sempre mais elevados do que os da microbacia B. Após o corte a microbacia teve um aumento significativo, principalmente para condutividade, cor, turbidez e sedimentos em suspensão.

Os sedimentos em suspensão na água do deflúvio totalizaram perdas médias da ordem de 19,8 e 24,0 kg.ha ${ }^{-1}$.ano ${ }^{-1}$, respectivamente para 
microbacia A e microbacia B (antes do corte) e 41,5 kg.ha ${ }^{-1}$.ano ${ }^{-1}$ (após o corte) para microbacia $\mathrm{A}$, em termos médio para o período. Devido à problemas ocorridos em equipamento no campo, não foi possível obter dados de deflúvio na microbacia $\mathrm{B}$ para a maior parte do último ano do período experimental.

A produção de biomassa acima do solo para plantação de $E$. saligna aos sete anos de idade totalizou 178,1 tha, assim distribuídos: $145,2 \mathrm{t}$ de lenho, 14,7 $\mathrm{t}$ de casca, 13,62 $\mathrm{t}$ de ramos e 4,6 t.ha ${ }^{-1}$ de folhas. A quantidade de nutrientes contidos na biomassa total foi de $200,8 \mathrm{~kg}$ de N, 52,8 de P, 308,3 kg de $\mathrm{K}, 796,1 \mathrm{~kg}$ de $\mathrm{Ca}, 133,13 \mathrm{~kg}$ de $\mathrm{Mg}$ e $30,6 \mathrm{~kg}$ de S. 


\title{
THE EFFECT OF CLEARCUTTING OF EUCALYPTUS PLANTATION ON THE WATER AND NUTRIENT BUDGETS OF A SMALL CATCHMENT.
}

\author{
Author: ANA ROSA TUNDIS VITAL \\ Advisor: Prof. Dr. WALTER DE PAULA LIMA
}

\section{SUMMARY}

This work studied the water balance in two adjacent catchments reforested with Eucalyptus saligna Smith. and the clearcutting effect on the water balance, chemical and physical parameters of water quality, nutrient cycling, soil losses and quantities of mineral nutrients exported with the woody biomass after the treatment in one of the catchments.

The experimental catchments are located in the Vale do Paraiba, Fazenda Bela Vista III, which belongs to Votorantim Celulose e Papel S/A, between the coordinates $25^{\circ} 25^{\prime}$ South and $45^{\circ} 54^{\prime}$ West from Greenwich, with $695 \mathrm{~m}$ average altitude, municipality of Santa Branca, State of São Paulo, where the climate is Cwa type, according to Köeppen classification, characterized as dry Winter temperature, where the annual average precipitation is $1.562 \mathrm{~mm}$.

The soils in the region are predominantly type Hapludult.

The catchment A has an area of 7.0 ha, 3.3\% of which is riparian vegetation, with $19.6 \%$ average slope; the area of the catchment $B$ is 6.5 ha, with $2.1 \%$ of riparian vegetation and with an average slope of $28.9 \%$.

The total experiment period was eight years, with comparison made between data from 7 years before the clearcutting and data obtained during the first year after the clearcutting. The catchment $\mathrm{B}$ remained with inalterated Eucalyptus plantation.

Besides the precipitation and streamflow, rain water and streamflow samples were obtained during the experimental period, to analyze the water quality and the geochemical cycling of the following nutrients: $\mathrm{NO}_{3}^{-}, \mathrm{K}^{+}, \mathrm{Ca}^{++}$, $\mathrm{Mg}^{++}, \mathrm{Fe}^{++}$and $\mathrm{Na}^{+}$.

The quantity of exported nutrients with the woody biomass was obtained from the estimative of the arboreous biomass and the nutrients content (phytomass and mineralmass, respectively). 
During the eight years of the experimental period, the water balance of the two catchments showed the following average values:

Catchment A:

Before clearcutting ( 7 years average): Precipitation: $1329 \mathrm{~mm}$ Streamflow: $145 \mathrm{~mm}$

After clearcutting (1 year): Precipitation: $1321 \mathrm{~mm}$

Streamflow: $115 \mathrm{~mm}$

Catchment B:

7 years average: Precipitation: $1329 \mathrm{~mm}$

Streamflow: $201 \mathrm{~mm}$

The evapotranspiration of the experimental period was $1562 \mathrm{~mm}$ in catchment A, representing $89.1 \%$ of the annual average precipitation and 1.129 $\mathrm{mm}$ in catchment $\mathrm{B}$, representing $84,9 \%$ of the annual average precipitation (before clearcutting) and $1205 \mathrm{~mm}$ in catchment A, representing $91.3 \%$ of the annual average precipitation (after clearcutting).

The difference between the nutrients inputs through precipitation, and outputs through streamflow showed the following results of goechemical balance in kg.ha" ${ }^{-1}$ year ${ }^{-1}: \mathrm{NO}_{3}^{-} 8.81 ; \mathrm{K}^{+} 0.91 ; \mathrm{Ca}^{++} 1.47 ; \mathrm{Mg}^{++} 0.37 ; \mathrm{Fe}^{++}-1.91 ; \mathrm{Na}^{+} 1.69$ to the catchment $\mathrm{A}$ and $\mathrm{NO}_{3}{ }^{-} 8.44 ; \mathrm{K}^{+} 2.75 ; \mathrm{Ca}^{++} 2.04 ; \mathrm{Mg}^{++}-0.16 ; \mathrm{Fe}^{++} 0.06 ; \mathrm{Na}^{+}$ 0.33 to the catchment $\mathrm{B}$ (before clearcutting) and $\mathrm{NO}_{3}{ }^{-} 8.19 ; \mathrm{K}^{+} 1.14 ; \mathrm{Ca}^{++} 4.47$; $\mathrm{Mg}^{++} 1.70 ; \mathrm{Fe}^{++}-4.63 ; \mathrm{Na}^{+} 1.92$ to the catchment $\mathrm{A}$ (after clearcutting).

The physical parameters conductivity, color and turbidity showed high variability in both catchments; $\mathrm{pH}$ and the electrical conductivity values remained almost inalterated during the first 7 years; in catchment $A$, these parameters were always higher than in catchment B. After clearcutting, the catchment had a significant increase, mainly for the parameter conductivity, color, turbidity and suspended sediments. 
The suspended sediments in the streamflow water totalized average losses of 19.8 and $24.0 \mathrm{~kg} \cdot \mathrm{ha}^{-1}$.year ${ }^{-1}$, respectively in catchment $\mathrm{A}$ and catchment $\mathrm{B}$ (before clearcutting) and $41.5 \mathrm{~kg} \cdot \mathrm{ha}^{-1} \cdot$ year $^{-1}$ (after clearcutting) to catchment $\mathrm{A}$.

Because of the problems happened with field equipment, it was not possible to obtain streamflow datas of catchment B in most part of last year of the experimental period.

The biomass production on the soil to the plantation of the $E$. saligna at seven years, totalized 178.1 ton.ha, distributed as: 145.2 ton of woody, 14.7 ton of bark, 13.62 ton of branches and 4.6 ton of leaves. The nutrients quantity contained in the total biomass was: N $200.8 \mathrm{~kg}, \mathrm{P} 52.8 \mathrm{~kg}, \mathrm{~K} 308.3 \mathrm{~kg}$, Ca $796.1 \mathrm{~kg}, \mathrm{Mg} 133.33 \mathrm{~kg}$ and $\mathrm{S} 3.06 \mathrm{~kg}$. 


\section{INTRODUÇÃO}

Apesar de a água ser um recurso natural renovável, em função dos processos físicos do ciclo hidrológico, não se pode considerá-la inesgotável. Em virtude do desenvolvimento urbano-industrial, as demandas hídricas crescem vertiginosamente e aliado a isto, o lançamento de esgotos industriais e urbanos, assim como a falta de planejamento e uso do solo vem causando comprometimento progressivo da qualidade das águas devido à consequência dos impactos sofridos pelas bacias hidrográficas.

Por outro lado, pesquisas estão sendo conduzidas no Brasil e em vários outros países, no sentido de buscar respostas experimentais para avaliar os efeitos de plantações florestais e outras práticas de uso da terra quanto as suas influências no meio ambiente, principalmente em termos do solo, dos recursos hídricos, micro clima, etc.

Em vários países, os estudos em microbacias hidrográficas experimentais vêm sendo conduzidos desde o início deste século. Tais estudos proporcionam um embasamento sobre a fase terrestre do ciclo hidrológico, no que diz respeito aos efeitos do uso da terra sobre a quantidade e qualidade de água que são produzidos nas microbacias. Alicerçados nestas pesquisas, decisões políticas e planos de manejo podem ser estabelecidos, possibilitando um mínimo de comprometimento da qualidade ambiental.

O estudo em microbacias pode ser desenvolvido através de correlação entre bacias, bacias isoladas e bacias pareadas (adjacentes). Em geral, 
estas bacias são monitoradas durante um certo período e podem, a seguir, receber tratamentos (por exemplo, o corte raso da floresta, preparo do solo, etc.), o que permite obter dados comparativos quanto ao comportamento de determinadas microbacias.

O presente trabalho consiste na avaliação do efeito do corte raso no balanço hídrico e na ciclagem de nutrientes em uma microbacia.

A evolução do uso do solo ao longo do Vale do Paraíba, semelhantemente ao que ocorreu em algumas outras regiões do País, envolveu a transformação da cobertura florestal original através da ocupação cíclica da canade-açúcar, seguida da cultura do café.

Após o colapso da cultura cafeeira, a atividade agrária na região caminhou rapidamente no sentido da predominância da pecuária leiteira. Todavia, em função da topografia acidentada da região, esta transformação da paisagem original conduziu a uma diminuição da capacidade natural de suporte do solo, resultante da erosão, da exaustão da fertilidade e da degradação de microbacias.

Presentemente, o reflorestamento com eucalipto é uma atividade crescente no Vale do Paraíba, principalmente para atender à demanda industrial de madeira para a produção de celulose e papel.

Do ponto de vista ambiental, o reflorestamento de eucalipto, em geral, é uma atividade polêmica, em função de uma opinião pública generalizada que the atribui efeitos ecológicos adversos (Lima 1993).

Quanto a este lado emocional da questão, o aspecto ambiental do reflorestamento com eucalipto ganhou ímpeto em anos recentes, mercê da mobilização mundial em torno dos problemas ecológicos do planeta. De fato, já não há mais lugar para atividades florestais que não estejam baseadas num 
cuidadoso plano de manejo, no qual o aspecto ambiental é de fundamental importância. E neste sentido, o conhecimento do funcionamento hidrológico da microbacia e a noção da microbacia como unidade ecossistêmica da paisagem, como referência para o planejamento do uso do solo, possibilitam a adoção de um critério bastante abrangente de manejo ambiental da floresta.

Preocupada com a necessidade de obtenção de informações e subsídios que pudessem nortear o estabelecimento de critérios ambientais de manejo de suas plantações de eucalipto ao longo do Vale do Paraíba, a Votorantim Celulose e Papel S/A, em convênio com IPEF e Departamento de Ciências Florestais da ESALQ/USP, instalou em abril de 1987, um projeto experimental em duas microbacias hidrográficas localizadas na Fazenda Bela Vista III, município de Santa Branca, Estado de São Paulo.

A hipótese deste estudo é no sentido de que os impactos causados pela colheita florestal do Eucalyptus saligna, através do corte raso, poderão implicar: em grande exportação de nutrientes do sítio, prejudicando as rotações futuras, caso os elementos retirados não sejam repostos; alteração na qualidade da água da microbacia, principalmente pela presença de sedimento em suspensão; e o aumento do deflúvio.

Tomando-se como base os resultados obtidos através da análise hidrológica dos dados disponíveis de precipitação, qualidade da água, concentração de nutrientes na água da chuva e do deflúvio, quantidade de biomassa seca e estoques de nutrientes nos diferentes componentes do E. saligna na microbacia A, o presente trabalho teve como objetivo avaliar os efeitos hidrológicos do corte raso em uma das microbacias experimentais, bem como o impacto e as possíveis alterações causadas ao meio ambiente, objetivando determinar os efeitos sobre: 

a) balanço hídrico;
b) a qualidade da água;
c) as perdas de nutrientes através do deflúvio, assim como o balanço geoquímico das microbacias;
d) as perdas de solo via sedimentos em suspensão no deflúvio;
e) as perdas de nutrientes pela exportação da biomassa lenhosa. 


\section{REVISÃO DA LITERATURA}

\subsection{Processos hidrológicos em microbacias}

Bacia hidrográfica é uma área topograficamente delineada que é drenada por um sistema de drenagem. A bacia é uma unidade da paisagem muitas vezes usada como uma unidade física-biológica e política-sócioeconômica para o planejamento e manejo de recursos naturais.

Para assegurar a sustentabilidade deste ecossistema, o planejamento do uso do solo deve envolver a adoção das chamadas práticas de manejo de bacias hidrográficas (Brooks et al. 1991; Whitehead \& Robinson 1993; Montgomery et al. 1995).

Manejo de bacias hidrográficas, neste sentido, significa o processo de orientação e organização do uso da terra e dos recursos naturais em uma bacia, para a produção de bens e serviços, sem afetar adversamente o solo e os recursos hídricos (Books et al. 1991).

Estudos em bacias hidrográficas são necessários para entender seu funcionamento hidrológico, visando o monitoramento da quantidade e da qualidade da água decorrentes do uso dos recursos naturais (Whitehead \& Robinson, 1993).

Os primeiros estudos em microbacias experimentais objetivaram, principalmente, relacionar o efeito da cobertura florestal, do reflorestamento e da substituição da vegetação sobre a produção de água, sobre a 
qualidade da água e sobre a ciclagem de nutrientes (Hoyt \& Troxell 1932; Likens et al. 1977; Whitehead \& Robinson 1993).

Experimentos em microbacias podem em geral ser classificados em três tipos principais: a) correlação entre múltiplas bacias; b) bacia individual autocalibrada; c) estudos em bacias pareadas (Mc Culloch et al. 1993). O método de bacias pareadas consiste em se relacionar pelo menos duas microbacias próximas uma da outra, com forma, topografia, vegetação, geomorfologia e solos similares. Assim uma permaneceria inalterada, servindo de controle, enquanto as demais sofreriam algum tratamento, por exemplo, o corte raso da cobertura florestal.

Deste modo, a resposta hidrológica de uma determinada bacia pode ser estudada através da comparação entre os períodos pré tratamento, durante o qual se procede à calibração da bacia, e período pós-tratamento (Hewlett, 1982). De acordo com Brooks et al. (1991) o período de calibração pode ser de 5 a 10 anos.

Para verificar-se a influência da cobertura florestal sobre o regime hidrológico de uma bacia hidrográfica é necessário o estabelecimento do ano hídrico e do balanço hídrico, o qual de uma maneira simplificada pode ser representado de acordo com a equação:

\section{$E T=P-Q$}

onde $\mathrm{P}$ é a precipitação média anual, ET é a evapotranspiração anual, e Q é o deflúvio. 
Estes componentes hidrológicos são também parâmetros básicos para verificar e quantificar os nutrientes no ecossistema, como também a relação e interação destes nutrientes com a vegetação e o solo.

Os efeitos causados por plantações florestais são estudados principalmente em bacias pareadas e, de um modo geral, a remoção da floresta conduz a um aumento no deflúvio e o reflorestamento de áreas abertas geralmente resulta em declínio na produção de água (Hornbeck \& Ursic 1979; Feller \& Kimmins 1984; Bruijnzeel 1990; Brooks et al. 1991; Whitehead \& Robinson 1993; Neary \& Hornbeck 1994; Rowe \& Pearce 1994; Tamm 1995). Isto pode ser verificado tanto em florestas tropicais (Bruijnzeel, 1990) como em florestas temperadas (Dye \& Poulter, 1995).

Um princípio básico em hidrologia florestal é o de que a produção de água e o regime fluviométrico de uma bacia hidrográfica são significativamente influenciados pela presença da cobertura florestal.

De acordo com Fahey (1994), o reflorestamento em áreas de pasto pode reduzir a produção de água em $30-50 \%$ decorridos 5-10 anos após o plantio, assim como o escoamento direto e os picos de enchente também podem ser reduzidos em até $50 \%$. Este autor sugeriu que práticas silviculturais tais como, controle do sub-bosque através de desbaste (diminuindo a densidade do povoamento), e um maior intervalo de tempo entre os plantios, tem o potencial para aumentar a produção de água.

Brooks et al. (1991) descrevem que a mudança no deflúvio é geralmente atribuída à alteração na evapotranspiração, e que a produção de água aumenta quando: (1) florestas são cortadas ou desbastadas; (2) a vegetação da microbacia é convertida de espécies com raízes profundas para espécies com 
raízes rasas; (3) substituição da cobertura florestal com espécies com baixa capacidade de ịnterceptação.

O conhecimento da hidrologia de microbacias florestadas é, sem dúvida, um importante subsídio para adoção de práticas de manejo florestal visando a sustentabilidade do ecossistema. A produtividade de uma dada área florestal depende, basicamente, do capital de nutrientes do solo.

De acordo com Bormann \& Likens (1967) e Likens et al. (1977), a bacia hidrográfica permite a quantificação do chamado balanço geoquímico de nutrientes, obtido pela comparação entre a entrada de nutrientes pela precipitação e saída via deflúvio, após a interação destes elementos com o solo.

A transferência dos elementos químicos para dentro do ecossistema se dá através da chuva, deposição de poeira e aerosóis, por fixação de microorganismos acima e abaixo do solo, adubação mineral e, exceto para o nitrogênio, por intemperismo da rocha matriz. As perdas, por sua vez, ocorrem através do escoamento superficial da água, da lixiviação profunda, volatilização, do deflúvio, e, evidentemente, pela exploração florestal.

A entrada de nutrientes pela precipitação varia de acordo com a localização e de acordo com as condições climáticas.

Consequentemente a quantidade de nutrientes tranportados pelo deflúvio em bacias hidrogáficas constituem um bom indicador do comportamento dos nutrientes em uma área (Bruijnzeel, 1990). De acordo com Tamm (1995), o conhecimento destes nutrientes na ecologia florestal é de relativa importância para as tomadas de decisão dentro do manejo florestal e o planejamento da terra, dentro de uma dinâmica ambiental global. 
O’Loughlin (1994), monitorando a qualidade da água em microbacias na Nova Zelândia, observou que os cursos d'água que drenam florestas naturais maduras não perturbadas possuem alta qualidade de água, com baixa concentração de nutrientes dissolvidos, sólidos em suspensão e organismos microbiológicos.

Bruijnzeel (1991), em uma revisão sobre os ganhos atmosféricos (via precipitação) e perdas hidrológicas (via deflúvio) de $\mathrm{Ca}^{++}$, $\mathrm{Mg}^{++}, \mathrm{K}^{+}, \mathrm{P}$ e $\mathrm{N}$, para 25 áreas de florestas tropicais, sobre diferentes substratos geológicos, encontrou virtual acumulaçạ̃o de $\mathrm{P}$ para todos os casos, refletindo baixa mobilidade deste elemento. $\mathrm{O}$ autor conclui que existe uma necessidade de estudos mais cuidadosos do estoque de nutrientes em florestas tropicais, especialmente para $\mathrm{N}$.

De um modo geral, o balanço anual de entrada e saída para os nutrientes $\mathrm{Na}, \mathrm{K}, \mathrm{Ca}$ e $\mathrm{Mg}$ varia substancialmente entre as bacias. A saída de nutrientes através do deflúvio varia de elemento para elemento.

Jordan (1982), verificando o balanço geoquímico de nutrientes em uma floresta tropical na Venezuela, encontrou que para $\mathrm{Ca}^{++}, \mathrm{K}^{+}$, e $\mathrm{Mg}^{++}$a entrada via atmosfera foi consideravelmente mais alta do que a saída via deflúvio. Outrọs dados indicam que a floresta não é sucessional e se além disso, esta não eleva os níveis de cátions, isto sugere que o intemperismo não desenvolve um importante papel na economia de nutrientes do ecossistema, o qual, neste caso, aparentemente mantêm-se dos nutrientes atmosféricos transportados pela chuva.

Para o fluxo de nutrientes em floresta natural secundária (Mata Atlântica) na Serra do Mar, São Paulo, os valores encontrados na 
precipitação foram, em Kg.ha ${ }^{-1}$ ano $^{-1}: \mathrm{K}$ 5.43, Ca 2.87, Mg 1.08, N 11.79 e P 0.69 , enquanto que as perdas via deflúvio foram: $\mathrm{NO}_{3} 4.9, \mathrm{~K} 2.0, \mathrm{Ca} 7.8, \mathrm{Mg} 3.5 \mathrm{e}$ Na 12.4 (Arcova et al. 1985; Arcova \& Cicco 1987).

Golley et al. (1978), estudando de uma forma geral o ecossistema de uma floresta tropical úmida, na província de Darien (República do Panamá), registraram os seguintes valores quanto à saída de nutrientes da floresta através da água dos rios: $\mathrm{P} \quad 0.7 \mathrm{Kg}_{\mathrm{ha}}{ }^{-1} \cdot \mathrm{ano}^{-1}, \mathrm{~K} 9.3 \mathrm{Kg} \cdot \mathrm{ha}^{-1} \cdot \mathrm{ano}^{-1}$, Ca $163.2 \mathrm{Kg}_{\mathrm{ha}}{ }^{-1}$. ano ${ }^{-1}$ e Mg 43.6 Kg.ha' ${ }^{-1}$. ano ${ }^{-1}$.

A mobilização de nutrientes de uma bacia não obedece rigorosamente uma ordem de saída através do deflúvio. Por exemplo, Guthrie (1978) encontrou a sequinte ordem $\mathrm{N}^{+}>\mathrm{K}^{+}>\mathrm{Mg}^{++}>\mathrm{Ca}^{++}$. Por outro lado, Ranzini (1990) encontrou a seguinte ordem decrescente: $\mathrm{Fe}^{++}>\mathrm{Ca}^{++}>\mathrm{Na}^{+}>\mathrm{Mg}^{++}$para uma microbacia, e $\mathrm{Na}^{+}>\mathrm{K}^{+}>\mathrm{Mg}^{++}>\mathrm{Fe}^{++}$para a outra, de duas bacias estudadas na mesma área.

Ranzini (1990) também encontrou um balanço negativo para $\mathrm{Ca}^{++}, \mathrm{Na}^{+}, \mathrm{Mg}^{++}$e $\mathrm{Fe}^{++}$na ciclagem geoquímica de nutrientes em duas microbacias reflorestadas com Eucalyptus saligna. Resultados similares foram encontrados por Scardua (1994) para uma microbacia reflorestada com Eucalyptus saligna no município de Itatinga, São Paulo.

Para uma microbacia localizada em Fiji, Waterloo (1994), estudando a ciclagem de nutrientes, registrou um balanço geoquímico também negativo para $\mathrm{Ca}^{++}, \mathrm{Mg}^{++}$, e $\mathrm{Na}^{+}$, porém um balanço positivo para $\mathrm{N}^{+}>\mathrm{K}^{+}>\mathrm{P}$. Resultados similares foram verificados por Golley et al. (1978) para floresta tropical úmida. 
Por outro lado, Flin et al. (1979), verificando o efeito da conversão da floresta esclerófita nativa para plantações de Pinus radiata em Victoria, Austrália, relata um balanço positivo para $\mathrm{K}, \mathrm{Na}, \mathrm{Ca}, \mathrm{Cl}, \mathrm{NO}_{3}^{-}$e $\mathrm{PO}_{4}$, porém negativo para $\mathrm{Mg}$ em duas bacias experimentais.

Em floresta madura de E. obliqua na Autrália, Guthrie et al. (1978) observaram que o balanço geoquímico de cátions mostrou ser primariamente dependente da quantidade do deflúvio que deixa a bacia. Encontraram um balanço anual positivo para $\mathrm{Ca}^{++}$e negativo para $\mathrm{Mg}^{++}$, porém houve um ganho líquido de $\mathrm{Na}^{+} \mathrm{e} \mathrm{K}^{+}$, que variou com a quantidade do deflúvio.

Em face da complexidade que envolve os processos que ocorrem na bacia hidrográfica, inúmeros trabalhos têm sido desenvolvidos no sentido de entender as interrelações e implicações ecológicas da cobertura florestal, uma vez que esta contém o maior reservatório de nutrientes e existe um fluxo de nutrientes desta para o piso florestal através da serapilheira, precipitação interna, escoamento da chuva pelo tronco, os quais tornam-se enrriquecidos pelos nutrientes das folhas e casca.

A colheita florestal implica na perturbação ao ecossistema através das perdas de nutrientes para o perfil do solo, aumento da acidificação do solo, aumento da concentração dos nutrientes na água do deflúvio e, consequentemente, aumento das perdas de nutrientes da bacia hidrográfica (Dahlgren \& Driscoll 1994; Malmer \& Gripp 1994; Stevens et al. 1995), os quais proporcionam uma carência dos principais elementos nos solos florestais (Marison 1979; Ranger \& Bonneau 1986). 
2.2. Produção de fitomassa e acúmulo de nutrientes em plantações florestais

A quantidade de nutrientes num ecossistema florestal é representada pela somatória dos nutrientes contidos nos diferentes compartimentos das árvores. Porém diferentes espécies acumulam diferentes quantidades de nutrientes, visto que algumas árvores podem ser consideradas mais exigentes do que outras quanto à retenção dos nutrientes em seus compartimentos.

Waterloo (1994) evidenciou que mesmo dentro e entre povoamentos de Pinus da mesma idade consideráveis variações podem ser observadas na concentração de nutrientes para todos os componentes da árvore.

Em plantações de Pinus patula com idade variando de 8 a 34 anos, Feller \& Kimmins (1984) descrevem que o conteúdo de nutrientes na biomassa aérea aumentou com a idade das parcelas até 34 anos e encontraram os seguintes valores: Ca 2.102, N 1.911, Mg 875, K 478, P 285 e Na $82 \mathrm{Kg}^{-h^{-1}} \cdot \mathrm{ano}^{-1}$.

Hobert \& Robertson (1991), no Sudeste de Transval, África do Sul, verificando os componentes da biomassa aérea e a composição de nutrientes em 10 espécies de eucaliptos, encontraram as seguintes concentrações: para folhas, $\mathrm{N} 1.71 \%, \mathrm{P} 0.112 \%, \mathrm{~K} 0.83 \%$, Ca $0.34 \%$ e Mg $0.32 \%$, para galhos, $\mathrm{N}$ $0.28 \%$, P $0.036 \%$, K $0.49 \%$, Ca $0.47 \%$ e $\mathrm{Mg} 0.20 \%$, para casca, N $0.24 \%$, P $0.050 \%$, K $0.57 \%$, Ca $0.95 \%$, e Mg 0.29\%, para tronco, N 0.08\%, P 0.002\%, K $0.11 \%$, $\mathrm{Ca} 0.16 \%$ e $\mathrm{Mg} 0.02 \%$. As proporções por componente de biomassa foram similares para todas as espécies: $41,20,19$ e $17 \%$, respectivamente para lenho, casca, ramos e folhas. 
O acúmulo de nutrientes na fitomassa arbórea varia de elemento para elemento, em função das características nutricionais de cada espécie, dos diferentes níveis de fertilidade do solo e da idade da floresta. Portanto, o estoque de nutrientes na biomassa da planta depende da massa da vegetação produzida. Independentemente do porte e, consequentemente, do estoque de nutriente correspondente, qualquer biomassa desempenha papel importante no processo de ciclagem de nutrientes (White, 1987).

Normalmente, o acúmulo de nutrientes acompanha a expansão da biomassa arbórea, crescendo de forma linear ou exponencial e a taxas mais reduzidas quando o povoamento atinge a maturidade (Pritchett \& Fisher 1989).

Jorgensen \& Wells (1976) estudando plantações de Pinus taeda de 4 a 39 anos de idade, encontraram que o acúmulo máximo de nutrientes ocorre entre 10 e 15 anos de idade, um pouco antes do tempo em que as copas se fecham e possam cobrir inteiramente o solo.

Waterloo (1994) encontrou que as concentrações de N, P, K, geralmente aumentam na seguinte ordem: acículas $>$ casca $>$ ramos $>$ lenho, enquanto as concentrações de $\mathrm{Ca}$ e $\mathrm{Mg}$ decrescem na ordem: lenho>casca>ramos>acículas, em plantações de Pinus. Esta observações foram constatadas por Stevens et al. (1995), os quais verificaram que a maior concentração de N, P, K encontrava-se na copa nas plantações de Pinus; em contraste, o $\mathrm{Ca}$ estava presente em maior quantidade no tronco.

Feller \& Kimmins (1984), estudando Pinus patula no Sudeste da Índia, observaram que as mais altas concentrações da maior parte dos 
nutrientes foram encontradas nas folhas, mas o estoque máximo de nutrientes foi encontrado no tronco ( 58 a $85 \%$ do total de nutrientes da parte aérea).

Para E. camaldulensis, E. grandis e E. torelliana, Shumacher (1993) verificou que o compartimento copa representa cerca de $10 \%$ da fitomassa total e, armazena em média $24 \%$ do total de nutrientes da árvore. No compartimento casca encontraram-se as maiores quantidades do elemento cálcio, aproximadamente $60 \%$ do total.

Hansen \& Baker (1979), em estudo sobre remoção de biomassa e nutrientes em plantações intensivas de curta rotação, encontraram que não existem diferenças perceptíveis na concentração de nutrientes entre plantações intensivas de curta duração e povoamentos naturais. Todavia, devido a alta produção de biomassa em plantios florestais de cultivo intensivo, tanto o conteúdo total de nutrientes, quanto as taxas de retirada anual são também mais altas.

Poggiani (1987) encontrou as seguintes quantidades (Kg.ha $\left.{ }^{-1}\right)$ de nutrientes para E. saligna aos 11 anos de idade: para folhas, N 49.6, P 4.8, K 29.3, Ca 106.7 e Mg 11.8, ramos, N 31.7, P 11.1, K 40.4, Ca 296.3 e Mg 23.3, casca, N 25.1, P 12.2, K 47.9, Ca 448.4 e Mg 30.5, para lenho, N 112.6, P 30,1 K 72.9, $\mathrm{Ca} 103.1$ e $\mathrm{Mg} 15.9$, respectivamente.

Plantações de E. tereticornis, aos 8 anos de idade, no Himalaia Central, apresentaram um total de biomassa de $126.7 \mathrm{tha}^{-1}$, contendo $\mathrm{N}$ 43.8, 19.8, 27.3 114.4 Kg.ha ${ }^{-1}$, P 4.40, 1.90, 4.30, 6.60 Kg.ha ${ }^{-1}$ e K 37.0, 31.0 51.6, 80.0 Kg.ha ${ }^{-1}$ para lenho, casca, ramos e folhas, respectivamente (Bargali \& Singh, 1991). O resultado dos vários parâmetros utilizados pelo autor para expressar a translocação eficiente destes nutrientes, sugere que o Eucalyptus está 
demandando menos nutrientes do que muitas florestas naturais da região, e esta translocação eficiente de nutrientes é comparada com o P. roxburghii, o qual apresentou a mais alta taxa de eficiência de uso de nutrientes entre as espécies florestais no Himalaia.

Em florestas mistas nativas de Eucalyptus em Victória, Austrália, Stewart et al. (1990) descrevem um conteúdo de $21.2 \mathrm{Kg} \mathrm{ha}^{-1}$ para P.

Por outro lado, Poggiani (1985 e 1987) encontrou biomassa de 186 t.ha $^{-1}$ em plantações florestais de $E$. saligna aos 11 anos de idade com as seguintes distribuições: 4.1 t.ha $^{-1}$ nas folhas, 13.8 t.ha $^{-1}$ nos troncos, 9.5 t.ha $^{-1}$ na casca e 158.6 t.ha $^{-1}$ no lenho, contendo N $219 \mathrm{Kg} \mathrm{ha}^{-1}$, P $58 \mathrm{Kg} \cdot \mathrm{ha}^{-1}$, K $190 \mathrm{Kg} \cdot \mathrm{ha}^{-}$ ', Ca $954 \mathrm{Kg} \cdot \mathrm{ha}^{-1}$ e $\mathrm{Mg} 81 \mathrm{Kg} \cdot \mathrm{ha}^{-1}$ na biomassa total.

Schumacher (1993), estudando a fitomassa em E. camaldulensis, E. grandis e E. torelliana com diferentes idades encontrou, respectivamente, o peso seco de 126.1 t/árvore para a idade de 9 anos, 273.3 t/árvore para a idade de 9 anos e 171.3 t/árvore para a idade de 12 anos. Para o E. camaldulensis a distribuição foi de $2,2 \mathrm{t} /$ folhas, $11 \mathrm{t} /$ ramos, $10.7 \mathrm{t} /$ casca e 102.1 t/lenho.

O rápido aumento da demanda global por produtos florestais pode ser refletido através do crescente estabelecimento de plantações em escala industrial, bem como em menor escala em fazendas florestais. Por outro lado, a sustentabilidade destas plantações vem merecendo interesse crescente de pesquisas, especialmente nos trópicos, onde elas apresentam rápido crescimento $\mathrm{e}$ são em geral exploradas em regime de curta rotação. Estas questões tornam-se pontos importantes para objetos de pesquisa. 
De acordo com Nambiar (1996), estas pesquisas devem ser fundamentadas visando esclarecer as relações entre as características do solo e a produtividade, bem como o estudo de práticas de manejo que possam influenciar nestes processos.

\subsection{Impactos da colheita florestal}

Áreas florestais podem ser exploradas de diferentes maneiras, cada uma caracterizada por um certo grau de perturbação do solo. Estas alterações na vegetação e no solo podem influenciar o deflúvio, o fluxo de sedimento e a qualidade da água. O corte da floresta reduz a evapotranspiração anual e aumenta o deflúvio, e a recarga da água subterrânea (Brooks et al. 1991).

Neary \& Hornbeck (1994) em estudo sobre as características primárias, interna e externa do ambiente, que podem ser afetadas como resultado da colheita florestal, incluem os seguintes aspectos: qualidade do ar, quantidade e qualidade da água de superfície, quantidade e qualidade da água subterrânea, habitats da vida silvestre terrestre e aquática, e diversidade biológica.

Segundo o mesmo autor, as mudanças ambientais que resultam da colheita florestal de uma determinada área podem ter impactos positivos bem como negativos sobre outros componentes do ecossistema.

A avaliação dos efeitos da colheita da floresta sobre os processos do solo e a química da água é frequentemente feita pelo método de bacias pareadas e estudos ao longo desta linha demonstram que existe um padrão consistente de aumento do fluxo anual de nutrientes após o desmatamento. Há, todavia, grande variação entre os aumentos verificados entre as bacias estudadas. 
De acordo com Whitehead \& Robinson (1993), a diferença mais marcante quanto às diferentes respostas que têm sido observadas, quanto ao fluxo de nutrientes em microbacias, deve-se às condições climáticas, especialmente o regime de precipitação.

O aumento médio no deflúvio devido à colheita florestal fica em torno de 250mm/ano (Smith 1991; Rowe \& Pearce 1994), porém para cortes rasos, estes valores podem chegar a 550mm/ano segundo (Rowe \& Pearce, 1994).

Hornbeck \& Ursic (1979), após uma abrangente revisão da literatura nos USA sobre os efeitos hidrológicos do corte raso em microbacias, concluíram que a exploração intensiva pode ser compatível com a manutenção dos cursos d'água, desde que estes canais estejam protegidos e exista ainda um cuidadoso planejamento e adequada condução da operação de colheita.

Aliado ao aumento no deflúvio, também, ocorre um aumento na quantidade de nutrientes que deixam a bacia após o corte da floresta. Malmer \& Gripp (1994) descrevem que para a maioria dos nutrientes, principalmente, N, $\mathrm{P}, \mathrm{K}$, tornam-se positivamente correlacionados ao deflúvio durante a exploração florestal, comportamento este também verificado por Guthrie et al. (1978); Hopmans et al. (1987).

As concentrações iônicas e suas relações com deflúvio são variáveis. Em picos de vazão, as concentrações são geralmente menores do que em vazão de estiagem, devido, em grande parte, a um maior tempo de residência da água no solo.

Após vários tratamentos de exploração, a concentração de cátions mostrou-se maior em bacias mais susceptíveis à ocorrência de escoamento superficial (Hopmans et al. 1987; Rowe \& Fahey 1991). Por outro lado, Malmer 
\& Grip (1994), monitorando deflúvio em bacias pareadas na Malásia, encontraram que o efeito dos diferentes tratamentos sobre a química da água foi evidente tanto para escoamento direto como para o escoamento base.

Segundo Brooks et al. (1991), os processos hidrológicos como o escoamento superficial, assim como o uso do solo e as práticas de manejo, afetam direta e indiretamente a qualidade da água nas microbacias, devido erosão do solo, e depọsição de sedimentos ao longo dos cursos d'água. Este autor ainda conclui que a qualidade física do deflúvio naturalmente existente é determinada, em grande parte, pela quantidade de sedimento que este carrega.

A presença de nutrientes na água do deflúvio após corte raso é diretamente proporcional à área explorada. Após o corte, ocorre ainda um aumento na quantidade de sedimentos em suspensão nos cursos d'água, e consequentemente a elevação da concentração de nutrientes, dependendo dos fatores do solo e da área (Rowe \& Pearce 1994; Stevens et al. 1995).

De acordo com Neary \& Hornbeck (1994), a produção de sedimento reflete as condições climáticas, hidrologia, geologia, solos, vegetação e regiões fisiográficas, e uso do solo para cada bacia hidrográfica. Estes mesmos autores encontraram que as taxas naturais de sedimentos em microbacias florestadas são normalmente baixas $\left(<100 \mathrm{Kg} \cdot \mathrm{ha}^{-1} \cdot \mathrm{ano}^{-1}\right)$ mas, estes valores podem ser até 5 vezes maior. A perda da força estabilizadora do solo, principalmente em áreas declivosas, decresce de 4 a 8 anos após a colheita devido a morte das raízes, predispondo as encostas ao mecanismo de avalanche.

Portanto, a proteção e manutenção da qualidade da água é uma meta fundamental no manejo de bacias hidrográficas. Para alcance desta 
meta, segundo Lowrance et al. (1984), a mata ciliar é importante no controle de sedimentos e de nutrientes para os cursos d'água.

O ecossistema ripário comporta-se como sistema filtrador, absorvendo nutrientes carreados principalmente pelo escoamento superficial das partes mais elevadas da área da microbacia, contribuindo assim para manter a qualidade do deflúvio das microbacias.

Duas práticas alternativas de colheita florestal, que envolveram a diminuição da área de corte raso e cortes em faixas, foram analisadas em microbacias na Floresta Experimental de Hubbard Brooks, New Hamphire, USA, para determinar seus impactos sobre a produção de água e concentração de nutrientes do deflúvio. Os resultados mostraram que o corte em faixa gerou um aumento no deflúvio médio anual 10 vezes menor do que o corte raso. Para os primeiros 4 anos após a colheita com corte em faixas, o aumento das concentrações nos cursos d'água foram: $\mathrm{NO}_{3} 7 \mathrm{mg} / 1$, Ca $0,9 \mathrm{mg} / 1, \mathrm{~K} 0,3 \mathrm{mg} / \mathrm{l}$, sendo que houve uma diminuição de $1,5 \mathrm{mg} / 1$ de Sulfato. Em contraste, os mesmos autores encontraram que a diminuição da área de corte raso causou um aumento máximo para $\mathrm{NO}_{3}$ de $23 \mathrm{mg} / \mathrm{l}$, Ca $3 \mathrm{mg} / \mathrm{l}$ e $\mathrm{K} 1 \mathrm{mg} / \mathrm{l}$ e um aparente decréscimo para Sulfato de $2 \mathrm{mg} / 1$ (Hornbeck et al. 1975; Whitehead \& Robinson 1993).

Hopmans et al. (1987) descrevem um estudo da dinâmica de nutrientes na precipitação e qualidade química no deflúvio para 3 bacias com floresta nativa de Eucalipto que sofreu corte e queima e posteriormente foi plantada com Pinus radiata em Victória, Austrália. Estes autores observaram que para a bacia tratada os elementos apresentaram a seguinte ordem de mobilidade 
para o balanço geoquímico: $\mathrm{Na}^{+}>\mathrm{Mg}^{++}>\mathrm{K}^{+}>\mathrm{Ca}^{++}$, sendo que somente o $\mathrm{Na}^{+}$e $\mathrm{Mg}^{++}$apresentaram diferenças em relação à bacia testemunha.

Ainda estes mesmos autores concluem que de um modo geral a mudança de eucaliptos para pinheiros não trouxe grandes alterações na qualidade da água do deflúvio, mas somente mudanças mínimas na química do deflúvio. Foi observado, contudo, que a exportação de nutrientes e a concentração de sólidos em suspensão foram significativamente maiores, o que foi explicado como tendo sido devido ao aumento da descarga da microbacia provocada pelo corte da floresta.

Atividades florestais associadas à colheita, tais como a construção de estradas e carreadores, podem degradar a qualidade da água, pelo menos imediatamente após a atividade, particularmente pelo aumento de sedimentos em suspensão nos rios (Hopmans et al. 1987; O’Loughlin 1994).

Bruijnzeel (1986), em uma revisão crítica com referência a influência da floresta sobre a chuva, produção de água, quantidade de nutrientes no deflúvio e balanço de nutrientes, admite que muita das chamadas influências benéficas, atribuídas à permanência da floresta, parecem ser exageradas. Este autor conclui que, os impactos ambientais adversos são devido a ineficientes práticas do uso do solo após a exploração.

Por exemplo, Neary \& Hornbeck (1994) após uma abrangente revisão da literatura quanto as práticas de manejo que tem sido desenvolvidas em diferentes regiões e países, no sentido de proteger os recursos hídricos, principalmente quanto a sedimentação durante e após as operações de colheita, encontraram que a construção e manutenção de estradas para exploração e vias de 
baldeio e transporte das toras no local, são as fontes primárias para $90 \%$ do sedimento gerado no processo de colheita.

A tendência do aumento do fluxo de nutrientes na água do deflúvio após a colheita florestal parece ocorrer, principalmente, nos dois primeiros anos após o corte da floresta, voltando aos níveis pré-tratamento após algum tempo, que tem variado de 1.5 a 5 anos (Hopmans et al. 1987; Hornbeck \& Kropelin 1982; Feller \& Kimmins 1984; Dahlgren \& Driscoll 1994; Stevens et al. 1995).

O’loughlin (1994) lembra que práticas de manejo tais como planejamento de exploração, desenvolvimento de técnicas de colheita com baixo impacto e estabelecimento de zonas tampão nas margens dos cursos d'água podem efetivamente proteger os cursos d'água, estabilizar encostas e prevenir o assoreamento dos cursos d'água.

Além das perdas de nutrientes, após a exploração, para os cursos d'água, a exportação de nutrientes de um ecossistema florestal é sempre proporcional à quantidade de biomassa exportada ou os diferentes componentes (lenho, casca, ramos e folhas) que são retirados do sítio.

A sustentabilidade florestal, relativamente ao capital de nutrientes, está baseada na premissa de que a remoção de nutrientes essenciais apresente uma taxa menor ou igual àquelas que ocorrem por processos naturais, tais como a deposição atmosférica, fixação biológica de nitrogênio e intemperismo.

Uma avaliação completa da quantidade de nutrientes exportados do sítio por uma dada plantação florestal deve incluir os seguintes aspectos: a concentração de nutrientes dentro dos vários componentes da 
biomassa; o grau de utilização da biomassa (árvore inteira, só tronco, etc.); o período de rotação; a taxa de produção de biomassa, as perdas indiretas envolvidas no esquema de manejo da plantação, tais como a remoção do piso florestal ou serapilheira e erosão (Lima, 1993).

Marison (1979) e Ranger \& Bonneau (1986), numa discussão dos efeitos sobre a remoção de nutrientes através da colheita de diferentes espécies arbóreas, intervalo de rotação e a quantidade de biomassa produzida que é explorada, concluíram que uma mudança para rotações mais curtas conduz para uma carência de todos os principais elementos na maior parte dos solos florestais.

Stevens et al. (1995), verificando os efeitos da exploração convencional de Pinus (somente o tronco da árvore)(T) e da exploração total das árvores (AT) sobre a concentração de nutrientes inorgânicos na água do solo, concluíram que, a maior parte do $\mathrm{K} \mathrm{e} 1 / 3$ do $\mathrm{P}$ lixiviados dos resíduos florestais deixados da $(\mathrm{T})$ permaneceram um ano na solução de solo da área, sendo que menos da metade de $\mathrm{K}$ alcançou os canais.

Por outro lado, estes autores encontraram que a ausência de resíduos florestais resultou numa carência de $\mathrm{K}$ e $\mathrm{P}$ disponíveis sobre a área de (AT). $\mathrm{Na}$ área $(\mathrm{T})$, os resíduos florestais representam um balanço positivo de $\mathrm{N}$ inorgânico para 3 anos após a exploração. Contudo, em ambos os tratamentos (T) e (AT), uma disponibilidade de nitrato foi observada no solo, assim como nos canais de drenagem das áreas $(\mathrm{T})$.

De um modo geral, os trabalhos têm mostrado que na colheita florestal os efeitos são significativamente mais severos se a colheita total da árvore é praticada. 
A exploração da árvore como um todo parece ser possível sobre solos férteis, porém sobre alguns tipos de solos tropicais (mais pobres) mesmo a exploração parcial (somente lenho+casca) não serão sustentáveis sem adição de fertilizantes (Bruijnzeel, 1990). De acordo com Stevens et al. (1995), a exploração florestal e a remoção de nutrientes em produtos florestais esgota o estoque de nutrientes no solo, a não ser que as entradas atmosféricas e intemperismo reponham a perda destes elementos ou fertilizantes sejam aplicados.

Por outro lado, Nambiar (1996), analisando plantações de rápido crescimento e sua sustentabilidade, conclui que o efeito líquido de plantações sobre a sustentabilidade do solo depende das condições iniciais do solo, por ocasião do estabelecimento das plantações.

Jorgensen \& Wells (1986), em detalhado balanço dos nutrientes $\mathrm{K}$ e N, para diferentes sistemas de corte de Eucaliptus sp e Pinus oocarpa, sobre solos de alta e baixa fertilidade, concluiram que para alguns solos a aplicação suplementar de nutrientes é essencial para a manutenção de alta produtividade.

Quando a reposição de nutrientes não ocorre de uma forma natural ou antrópica, o crescimento pode ser prejudicado, como encontrado por Waterloo (1994) e Jordan \& Russel (1983), onde a segunda rotação foi menos produtiva do que a primeira, em plantações de Pinus e Gmelina.

Possíveis práticas de manejo para aumentar a utilização eficiente de nutrientes são: (1) aumentar o período de rotação; (2) deixar componentes com alto teor de nutrientes distribuídos sobre a área; (3) selecionar espécies ou clones com eficiente utilização de nutrientes (Hansen \& Backer, 1979). 
White \& Harvey (1979), sugerindo modificações das práticas de manejo intensivo, visando manter a produtividade sustentável do sítio, abrange desde nenhuma exploração sobre sítios extremamente pobres em nutrientes até empenho na reabilitação sobre áreas seriamente danificadas.

Visando a manutenção da produtividade do sítio, muitos estudos têm sido conduzidos no sentido de encontrar alternativas benéficas e viáveis para conduzir práticas de manejo sustentável, tais como, permanência de resíduos florestais no campo (Poggiani 1985; Schumacher 1992; Waterloo 1994; Cuevas 1996) e uso de resíduos industriais e urbanos (Guerrini 1996) e (Harrison et al. 1996), como fonte imediata de nutrientes disponíveis durante a sucessão ou estabelecimento das sucessivas rotações.

Guerrini (1996), estudando o uso de resíduos industriais em florestas, conclui que o uso de resíduos industriais produzidos pelas empresas florestais e utilizados como fertilizantes em seus próprios plantios é uma prática produtiva, econômica e ecologicamente saudável. Entretanto, alguns fatores devem ser considerados: a) constante monitoramento do solo e do lençol freático; (b) a granulometria, no caso das escórias, e o estado de decomposição, no caso dos materiais orgânicos, são fatores fundamentais para o sucesso da prática; $\mathrm{A}$ melhor época para se detectar alterações na fertilidade do solo e a nutrição das plantas decorrentes da utilização dos resíduos está entre 6 a 12 meses após a aplicação; (d) os experimentos analisados sugerem que, devido ao fato de os materiais corretivos de acidez do solo conterem muito cálcio, sua aplicação deveria estar condicionada a uma adubação complementar com $\mathrm{K}$. 
Portanto, resultados destas linhas de pesquisas devem contribuir para o contínuo melhoramento da produtividade florestal, bem como da qualidade ambiental. 


\section{MATERIAIS E MÉTODOS}

\section{1. Área experimental}

Grande parte das informações que caracterizam a área das microbacias é descrita por Ranzini (1990).

Tratam-se de duas microbacias hidrográficas, denominadas de $\mathrm{A}$ e $\mathrm{B}$, as quais foram selecionadas pelo fato de representarem bem as principais características topográficas da região e por serem adjacentes.

A área experimental localiza-se no Município de Santa Branca, Estado de São Paulo (Figura 1). As microbacias fazem parte da Bacia do Paraíba do Sul, pertencente à $6^{\mathrm{a}}$ zona hidrográfica e subzona hidrográfica 61 do Estado de São Paulo (DAEE, Caracterização dos Recursos do Estado de São Paulo, 1984). As mesmas fazem parte da Fazenda Bela Vista III. Suas coordenadas são de $23^{\circ} 25^{\prime}$ de latitude Sul, e $45^{\circ} 54^{\prime}$ de longitude a Oeste de Greenwich. Possuem altitude que varia de $665 \mathrm{~m}$ a $725 \mathrm{~m}$.

A microbacia A possui uma área de 7,0 ha, sendo 3,3\% ocupada por mata ciliar, com uma declividade média de $19,6 \%$; a microbacia $\mathrm{B}$ tem uma área de 6,5 ha, dos quais $2,1 \%$ são de mata ciliar, com uma declividade média de $28,9 \%$. 


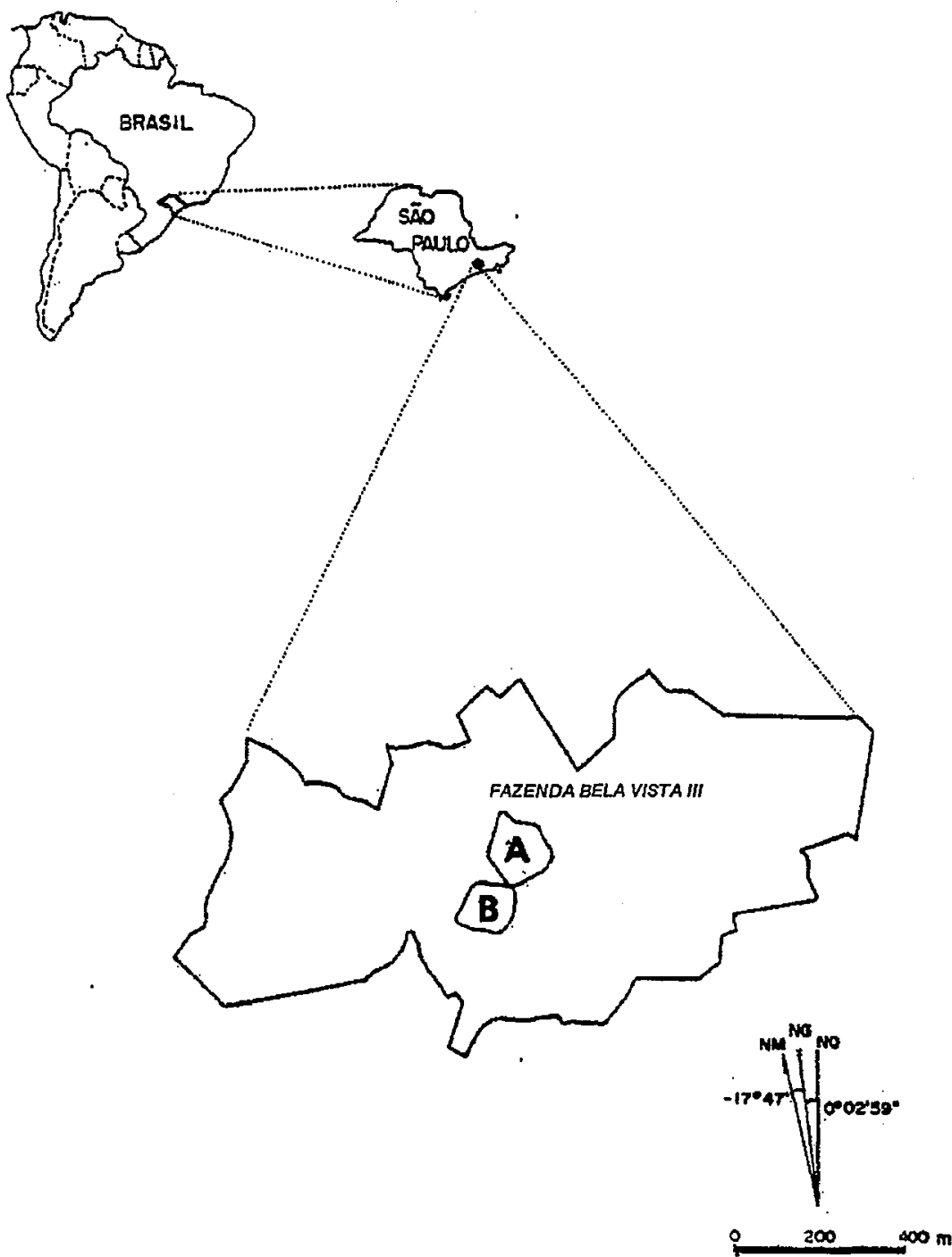

CROQUI DE LOCALZAÇÃO semescala

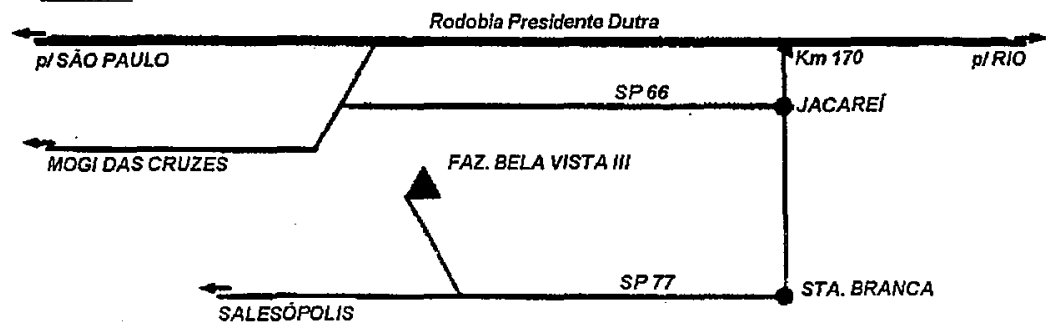

Figura 1. Localização da área experimental. 
As duas microbacias foram reflorestadas com Eucalyptus saligna Smith. Em abril de 1987 e receberam preparo do solo diferenciado devido à diferença na declividade; na microbacia $\mathrm{A}$, o preparo do solo consistiu em roçada, queimada e aração a $20 \mathrm{~cm}$ de profundidade com arado de disco; na microbacia $\mathrm{B}$, o plantio foi realizado pela abertura de covas; após a roçada e a queimada, foram abertas covas com a dimensão de $30 \mathrm{~cm} \times 30 \mathrm{~cm} \times 30 \mathrm{~cm}$. As microbacias tiveram as matas ciliares preservadas.

\subsubsection{Clima}

A região possui uma precipitação média anual de $1.562 \mathrm{~mm}$ (DAEE, Totais Mensais de Chuva do Estado de São Paulo, 1993). A temperatura máxima média é de $26^{\circ} \mathrm{C}$ e a temperatura mínima média é de $17^{\circ} \mathrm{C}$, resultando em uma temperatura média compensada em $22^{\circ} \mathrm{C}$ (Nascimento \& Pereira, 1988).

Segundo a classificação de Köeppen, a área compreende o tipo climático Cwa, que corresponde ao clima temperado de inverno seco.

Durante o período experimental a média anual de precipitação foi de $1.329,4 \mathrm{~mm}$.

\subsubsection{Geologia e geomorfologia}

A geologia é arqueana, pertencendo ao complexo Paraíba do Sul, que abrange um agrupamento composto por gnaisses bandados, migmatitos, lentes de quartzitos, anfibólitos, mármores e gnaisses granitóides (Projeto RADAMBRASIL, 1983).

Morfologicamente, pertence aos domínios morfo-estruturaisfaixas de dobramentos remobilizados, região das escarpas e reversos da serra do mar, cuja topografia em toda a sua extensão, apresenta vales alongados, 
segmentos de drenagem retilíneos, linhas de cristas e de cumeadas paralelas, relevos com grandes desníveis altimétricos e escarpas. A unidade geomorfológica é o planalto do Paraitinga-Paraibuna, onde o comportamento espacial da rede de drenagem se apresenta fundamentado na organização tectônica da área, com padrão retangular a subdendrítico adaptado aos sistemas de falhas e fraturas (Projeto RADAMBRASIL, 1983).

\subsubsection{Solos}

Os solos da área experimental pertencem à classe do Podzólico Vermelho-Amarelo álico $\mathrm{Tb} \mathrm{A}$ moderado textura média/argilosa (Apêndice 1 e 2) (FLORIN $\left.{ }^{1}, 1988\right)$.

A microbacia A apresenta como material de origem a cobertura colúvio/aluvionar Pleistocênico sobre a sericita-xisto. $O$ colúvio por se tratar de um material pré-intemperizado, ocasiona as seguintes características (Ranzini, 1990): topografia mais suave, solos mais profundos, menor gradiente textural entre os horizontes $\mathrm{A}$ e $\mathrm{B}$, maior porcentagem de argila floculada que na microbacia $\mathrm{B}$, e maior infiltração de água:

O material de origem da microbacia $B$ é o mesmo da microbacia A, com exceção do seu terço inferior onde não ocorre o recobrimento pleistocênico. As encostas íngremes da microbacia B apresentam, de acordo com Ranzini (1990), o horizonte A do solo pouco espesso, chegando em alguns pontos, a aflorar o horizonte B.

A microbacia B apresenta um gradiente textural acentuado (24,7\% de argila no horizonte A contra 40,9\% no horizonte B) (Apêndice 2)

\footnotetext{
${ }^{1}$ FLORIN. Levantamento agroecológico das áreas da FLORIN no Vale do Paraíba: relatório interno. Jacareí, 1988. 151p.
} 
(FLORIN, 1988), fazendo com que haja uma redução da velocidade de infiltração da água no horizonte $\mathrm{A}$ para o horizonte $\mathrm{B}$, favorecendo o escoamento superficial.

\subsubsection{Vegetação}

A vegetação original da região era do tipo ombrófila densa (Projeto RADAMBRASIL, 1983).

Atualmente a influência antrópica, que resultou na substituição da vegetação original por pastagens e reflorestamentos de eucaliptos, alterou completamente a fisionomia vegetal (Ventura et al. 1965/66).

No trabalho de aptidão Agrícola das Terras de São Paulo, o Município de Santa Branca localiza-se na mesoregião 259 - Vale do Paraíba paulista da mesoregião 2, concluindo que tem aptidão boa para pastagem plantada e cultura de ciclo longo, sendo inapta para culturas de ciclo curto (BRASIL, 1979).

A fazenda florestal onde se encontram localizadas as microbacias foi reflorestada em abril de 1987. A espécie utilizada foi o Eucalyptus saligna Smith., plantado em espaçamento de $3 \mathrm{~m} \times 2 \mathrm{~m}$, com adubação de base (200 gramas/cova) de super fosfato simples.

\subsection{Métodos}

3.2.1. Fluviometria e pluviometria

A instrumentação teve início em março de 1987, para medição da precipitação e vazão nas microbacias A e B. O período de coleta foi de junho de 1987 à maio de 1995. 
Foram instaladas duas estações fluviométricas dotadas de vertedores triangulares de $90^{\circ}$ (Figura 2).

O vertedor de $90^{\circ}$ é um dispositivo preciso, adequado para a faixa de variação e fluxo previsto para a área (Ranzini, 1990). Na literatura internacional, esse vertedouro é frequentemente referido como o "vertedouro Thompson" (Bos, 1976).

Para a medição contínua da vazão foram utilizados dois linígrafos modelo Hidrologia, instalados um em cada estação fluviométrica (Figura 3). A calibragem semanal dos linígrafos foi feita por réguas linimétricas associadas aos vertedouros. Determinou-se a vazão por meio da equação de Thompson, específica para este tipo de vertedouro:

$$
\mathrm{Q}=1,34 \cdot \mathrm{H}^{2,48}
$$

onde,

$\mathrm{Q}=$ vazão $\mathrm{em} \mathrm{m}^{3} / \mathrm{s}$;

$\mathrm{H}=$ altura da lâmina d'água no vertedouro em metros.

Devido a um problema ocorrido com o linígrafo da estação fluviométrica da microbacia B, o registro da vazão no ano hídrico junho de 1994 a maio de 1995 ficou prejudicado. 


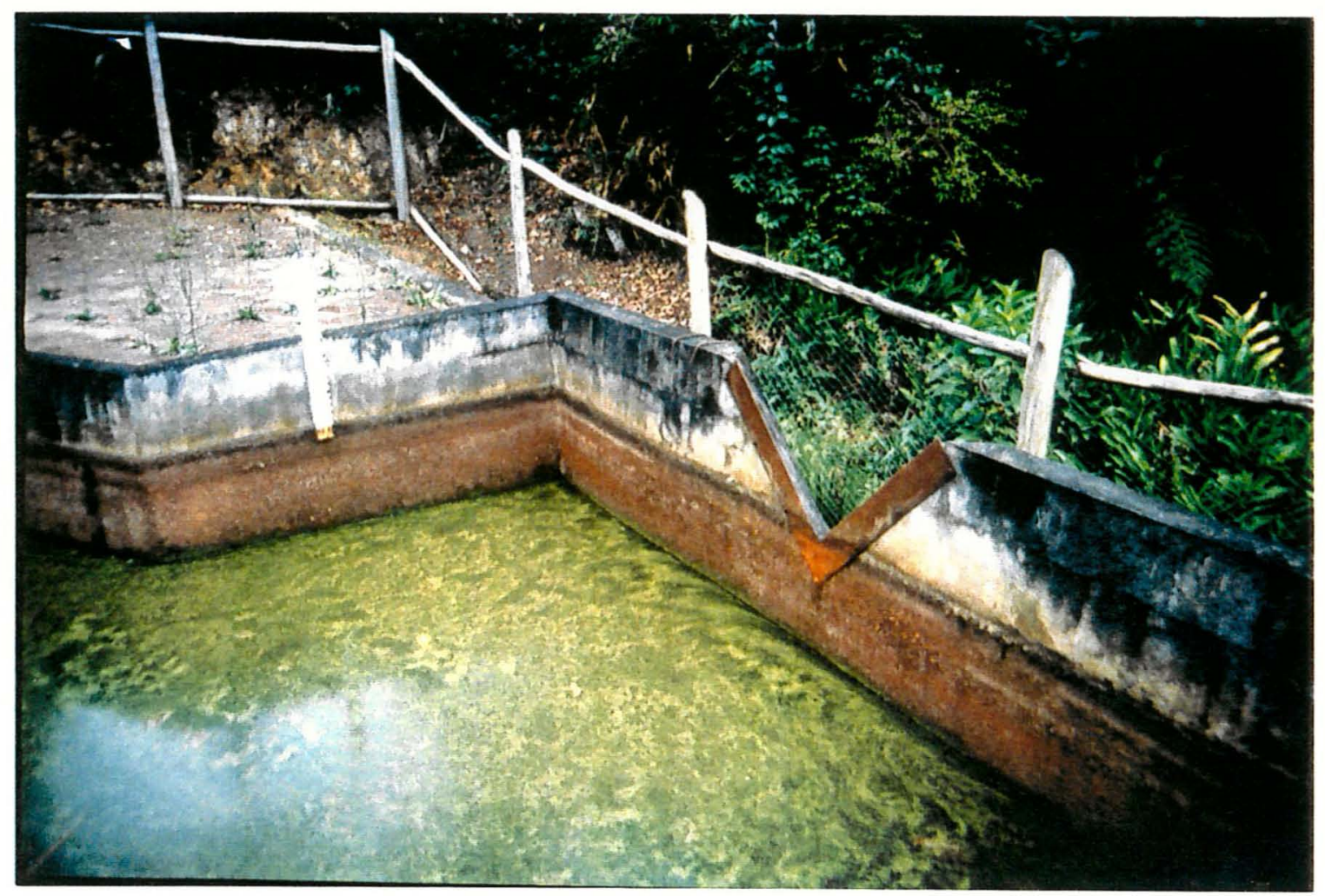

Figura 2. Estação fluviométrica com vertedor triangular de $90^{\circ}$.

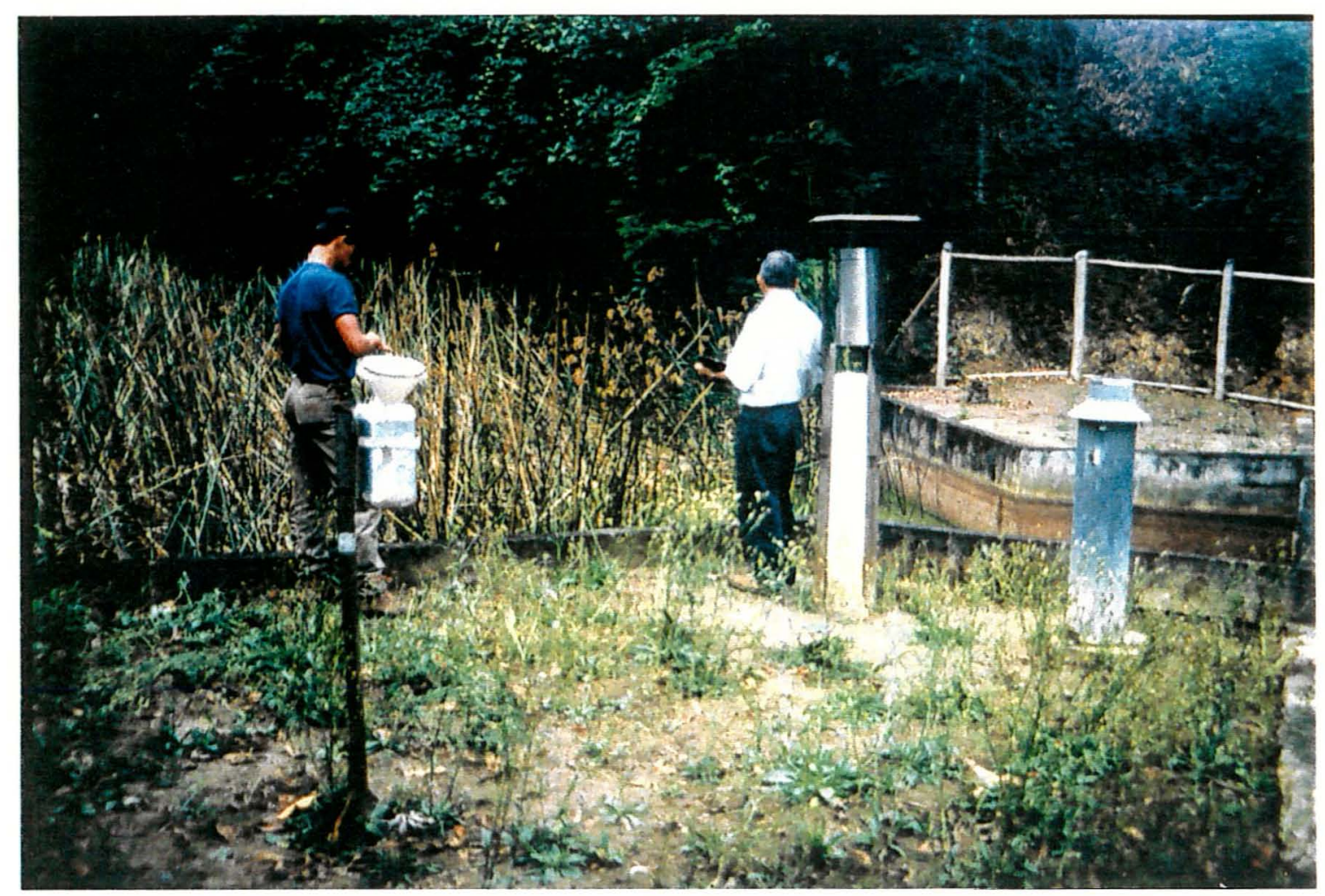

Figura 3. Estação fluviométrica com linígrafo modelo hidrologia. 
A tabulação dos dados de precipitação diária para as duas microbacias foi feita a partir dos dados obtidos por um pluviógrafo tipo Helmann, de rotação semanal, e tres pluviômetros tipo Ville de Paris, que constituíram a rede para a determinação, pela média aritmética, da precipitação semanal (Figura 4).

A troca dos diagramas do pluviógrafo e dos linígrafos foi semanal. O procedimento para tabulação do diagrama do pluviógrafo foi, em parte, baseado em Johnson \& Dils (1956). Para a tabulação do diagrama do linígrafo, o procedimento adotado foi realizado baseando-se em Johnson \& Dils (1956) e D.N.A.E.E. (1970).

\subsubsection{Parâmetros físicos e químicos}

Para amostragem da água da chuva foram instalados cinco coletores, quatro ao lado de cada pluviômetro e um ao lado do pluviógrafo. $\mathrm{O}$ modelo utilizado foi o descrito por Coutinho (1979).

Cada coletor é constituído por uma garrafa de polietileno, com um funil recoberto por uma tela de nylon para impedir a entrada de insetos ou qualquer outro objeto para o interior da garrafa, o qual foi instalado em lugar aberto, a 1,5 $\mathrm{m}$ acima do solo.

As amostras do deflúvio, em ambas as microbacias, foram coletadas no vertedor, em intervalos semanais, utilizando-se garrafas de polietileno com capacidade para 1 litro. As garrafas eram lavadas no laboratório, com solução de $\mathrm{HCl} 10 \%$ e enxaguadas várias vezes com água corrente, seguida de uma enxaguada com água destilada.

No campo, antes de proceder à coleta, as garrafas eram enxaguadas com água do deflúvio a ser amostrado. 
Os frascos com as amostras de água da chuva e do deflúvio das microbacias eram armazenados em geladeira. Mensalmente, foram transportados ao Laboratório de Ecologia Aplicada do Departamento de Ciências Florestais, da Escola Superior de Agricultura "Luiz de Queiroz" (ESALQ/USP), Piracicaba/SP, onde foram feitas as análises químicas e físicas.

A determinação dos elementos $\mathrm{K}^{+}, \mathrm{Ca}^{++}, \mathrm{Mg}^{++}, \mathrm{Fe}^{++}$e $\mathrm{Na}^{+}$ foram realizadas através de espectrofotometria de absorção atômica, utilizando equipamento marca PERKIN ELMER modelo 272 (Giolito, 1968). $\mathrm{O} \mathrm{NO}_{3}^{-}$foi analisado por colorimetria, pelo método da brucina.

As análises de turbidez, condutividade elétrica e $\mathrm{pH}$ foram realizadas seguindo-se as normas da AMERICAN PUBLIC HEALTH ASSOCIATION (1976), utilizando-se um turbidímetro modelo 2100A - HACH condutivímetro modelo 2511 - HACH e pontenciômetro modelo 3221 MICRONAL, respectivamente.

Os valores da alcalinidade para a água da chuva e do deflúvio foram obtidos por titulação com ácido sulfúrico $0,02 \mathrm{~N}$, e os valores de cor, por colorímetro fotoelétrico modelo B220 - MICRONAL, tendo-se como escala colorimétrica uma solução platino-cobalto (AMERICAN PUBLIC HEALTH ASSOCIATION, 1976).

Através da medição da precipitação pluviométrica e do deflúvio foi determinada a quantidade do fluxo de nutrientes, pela determinação da concentração iônica dos nutrientes $\mathrm{NO}_{3}^{-}, \mathrm{K}^{+}, \mathrm{Ca}^{++}, \mathrm{Mg}^{++}, \mathrm{Fe}^{++}$e $\mathrm{Na}^{+}$na água da chuva e do deflúvio, através da seguinte relação: 


$$
F n=\frac{P o u D \times C n \times 0,01}{t}
$$

onde,

$\mathrm{Fn}=$ fluxo de nutrientes $(\mathrm{Kg} / \mathrm{ha} / \mathrm{t})$;

$\mathrm{P}$ ou $\mathrm{D}=$ valores de Precipitação ou deflúvio $(\mathrm{mm})$;

$\mathrm{Cn}=$ concentração de nutrientes na água da chuva ou do deflúvio (mg/1);

$\mathrm{t}=$ tempo (semana, mês, ano, etc..).

\subsubsection{Sedimentometria}

A concentração de sedimentos em suspensão foi obtida de uma alíquota de $300 \mathrm{ml}$ de amostra, a qual foi filtrada utilizando-se membrana com poros de $0,45 \mu \mathrm{m}$, previamente seca em estufa $\left(110^{\circ} \mathrm{C}\right)$ durante 24 horas e pesada numa balança analítica. Após a filtragem, essa membrana foi seca, novamente em estufa, nas mesmas condições anteriores (Brown et al. 1970). Pesou-se e calculou-se a perda de solo provenientes dos sedimentos em suspensão, utilizando-se a expressão:

$$
P_{s}=\frac{D \times C s \times 0,01}{t}
$$

onde,

Ps = perda de solo $(\mathrm{Kg} / \mathrm{ha} / \mathrm{t})$;

$\mathrm{D}=$ valores de deflúvio $(\mathrm{mm})$;

$\mathrm{Cs}=$ concentração de sedimentos na água do deflúvio (mg/l);

$\mathrm{t}=$ tempo (semana, mês, ano, etc...). 


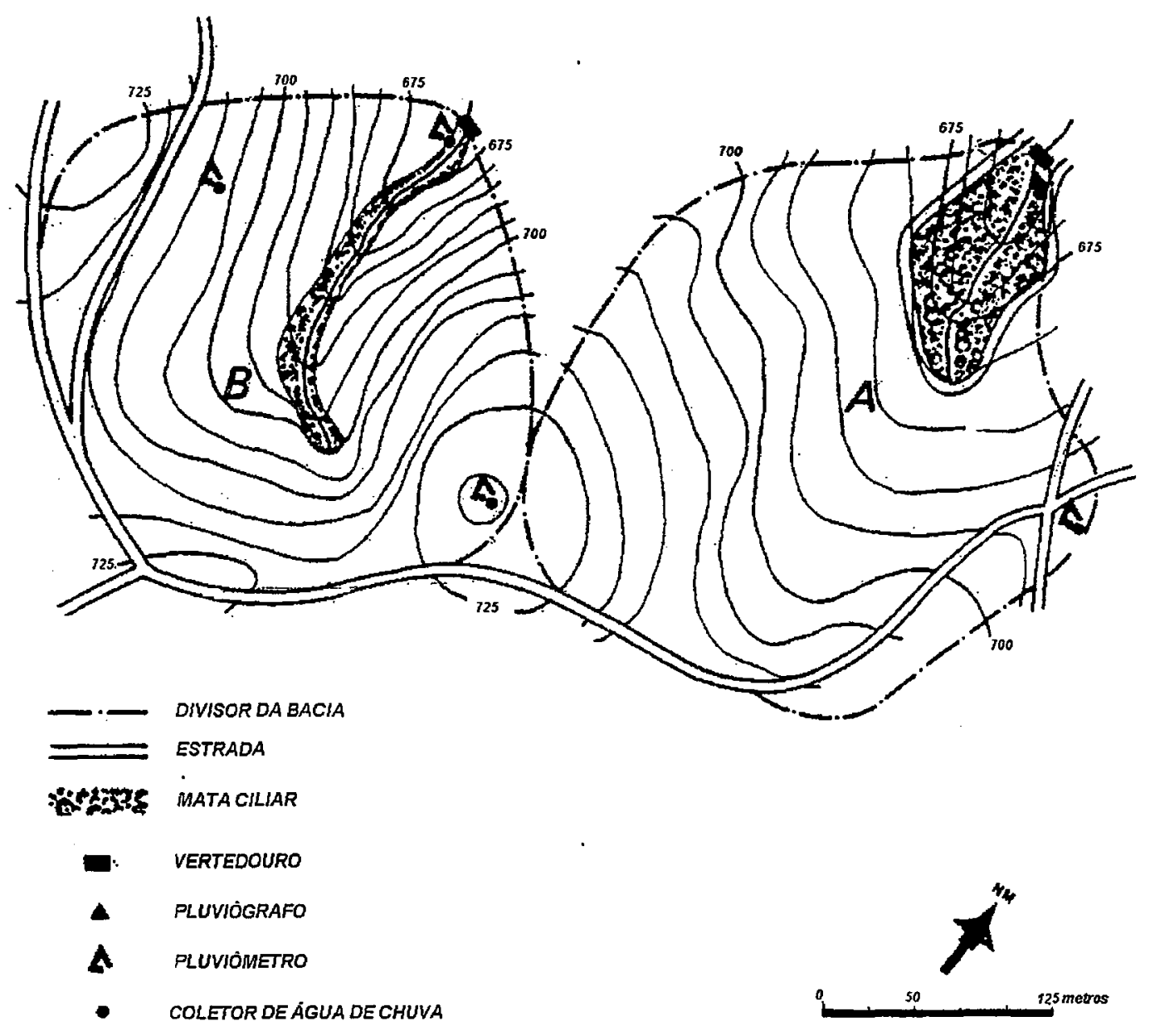

Figura 4. Área experimental com a distribuição de aparelhos para a medição da precipitação, da vazão e para a coleta de água da chuva. 
A perda de solo foi calculada a partir da concentração de sedimento nas amostras coletadas semanalmente.

Em junho de 1994, a microbacia A foi submetida ao corte raso da plantação de Eucalyptus saligna, aos 7 anos de idade (Figura 5). Após o corte, a rotina de coleta dos dados de precipitação e vazão continuaram por mais um ano. Previamente ao corte também foram obtidos os dados amostrais de biomassa lenhosa, bem como o estoque de nutrientes na biomassa acima do chão.

Por ocasião da colheita florestal da microbacia A, foi utilizada a malha viária já existente, não tendo sido aberto portanto novas estradas e carreadores.

O tipo de máquinas usadas no corte e na retirada do eucalipto foram: motosserra, trator florestal auto-carregável e trator com estrutura na retirada da madeira, sendo o trator de estrutura com carga manual (também conhecido como trator "berço").

O processo de colheita florestal envolveu a prática convencional, com 1 operador e 1 ajudante (o operador derruba, desgalha e traça no comprimento $2,40 \mathrm{~m}$ ). O descascamento foi realizado na fábrica.

As toras não foram arrastadas e o carregamento foi mecânico, no caso dos auto-carregáveis, e manual no trator de estrutura, o qual é utilizado nas áreas mais declivosas.

3.2.4. Estimativa da fitomassa e da mineralomassa da parte aérea das árvores

3.2.4.1. Escolha e corte das árvores representativas

$\mathrm{Na}$ primeira quinzena de junho de 1994, realizou-se a determinação da fitomassa arbórea da microbacia A. 
Primeiramente foi feito um inventário da área experimental, com o objetivo de caracterizar o povoamento de eucalipto no que diz respeito à variação existente entre os parâmetros diâmetro à altura do peito (DAP) e altura total e comercial.

Para tal finalidade foram escolhidas na microbacia $\mathrm{A}$, ao acaso, 4 parcelas de $20 \times 20 \mathrm{~m}\left(400 \mathrm{~m}^{2}\right)$, totalizando uma área de $1600 \mathrm{~m}^{2}$. Todas as árvores vivas tiveram seus diâmetros e suas alturas devidamente mensurados. As alturas foram estimadas a partir da relação hipsométrica ajustada para a área experimental. Para o cálculo do volume, foi utilizada a equação volumétrica, também ajustada para o local.

As árvores foram divididas em 5 classes, de acordo com seus diâmetros (Amplitude: de 3 a 8,0; de 8,1 a 13,0; de 13,1 a 18,0; de 18,1 a 23,0; de $23,1$ a $28,0 \mathrm{~cm})$.

Para amostragem, foram escolhidas 5 árvores por parcela inventariada e 4 árvores por classe de diâmetro, perfazendo assim, um total de 20 árvores (sem doença e sem defeito), com a finalidade de determinar através de pesagem no campo a massa de cada um dos componentes destas (lenho, casca, ramos e folhas).

\subsubsection{Determinação da massa seca das árvores amostrais}

Após o corte (Figura 6), as árvores foram medidas quanto ao diâmetro (DAP), altura total e altura comercial. Em seguida, as árvores foram submetidas a uma cubagem rigorosa ( $\mathrm{m}^{3}$ /árvore), onde foram determinados: volume total com casca, volume total sem casca, volume comercial com casca e volume comercial sem casca, segundo os métodos desenvolvidos pela empresa, semelhante ao utilizado por Couto \& Bastos (1987). Na parte intermediária da 
copa, levando-se em conta os quatro pontos cardeais, foram coletadas amostras de folhas e galhos para análise nutricional. Todos os compartimentos tiveram seu peso total determinado. Em função da altura comercial da árvore, o tronco foi dividido em 5 partes proporcionais $(0,25,50,75$ e 100\%) a diferentes alturas, das quais foi retirado 1 disco por fração.

Todas as amostras de folhas e ramos utilizadas para a determinação do teor de umidade foram pesadas ainda no campo, com auxílio de uma balança de precisão. Após a pesagem, devidamente identificadas, foram acondicionadas em sacos plásticos e posteriormente levadas para o laboratório.

A estimativa da densidade básica da madeira do tronco, como um todo, foi determinada a partir da densidade básica encontrada para cada disco (lenho+casca), utilizando-se o método de balança hidrostática, segundo a Norma TAPPI (T 258om - 89), utilizando se a expressão:

$$
D b_{\text {total }}=\frac{P S M+P S C}{P U T-P I T}
$$

onde,

$\mathrm{PSM}=$ peso seco da madeira;

PSC $=$ peso seco da casca;

PUT $=$.peso úmido total;

$\mathrm{PIT}=$ peso imerso total.

De cada um dos discos foram retiradas duas amostras (cunhas em sentidos opostos), as quais foram saturadas em tanque com água e pesadas separarando-se a casca do lenho. Em seguida, as amostras foram colocadas em estufa à temperatura de $100^{\circ} \mathrm{C}$, até alcançar o peso constante. 
Para a determinação do peso da matéria seca do lenho e da casca de cada tronco, utilizou-se a média dos teores de umidade encontrados para as cunhas de madeira e dos semi-anéis de cascas retiradas à $0,25,50,75$ e 100\% da altura total do tronco. 


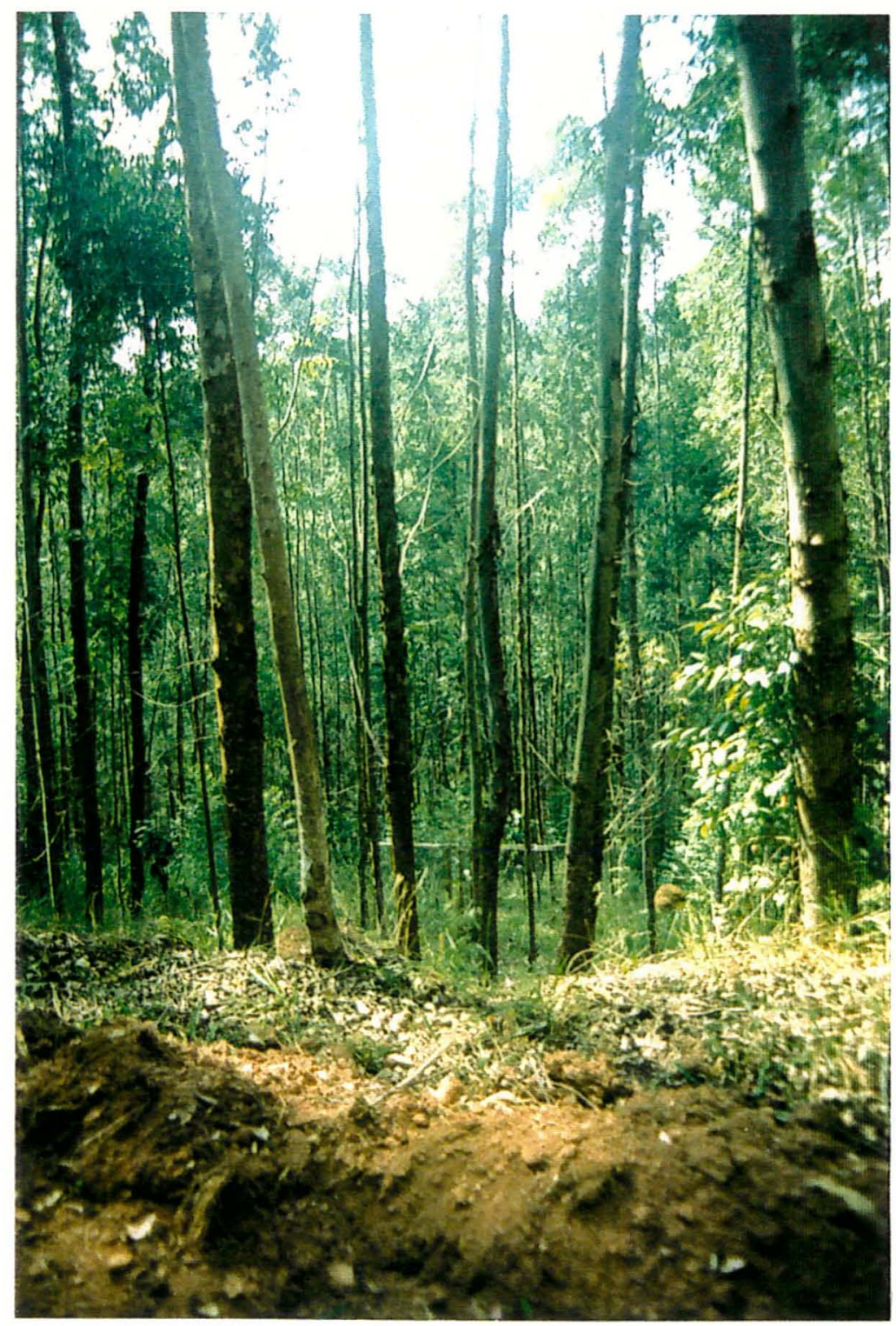

Figura 5. Vista da microbacia A com plantação de E. saligna aos 7 anos de idade. 


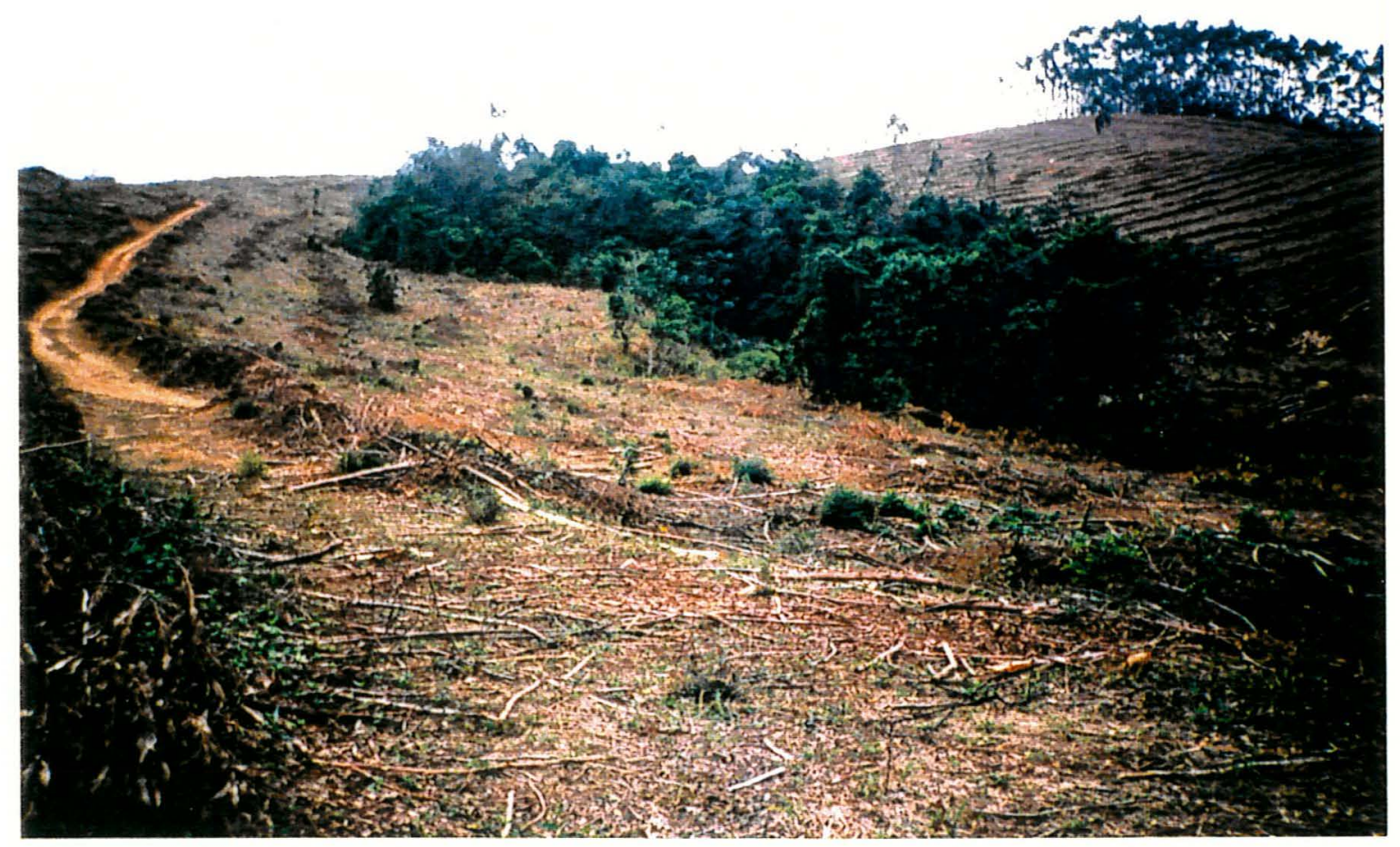

Figura 6. Vista da microbacia A após o corte. 
Para a determinação do peso da matéria seca das folhas e dos ramos foi utilizado o valor dos teores de umidade encontrados nas amostras e o peso úmido das mesmas retiradas em quatro pontos ortogonais da parte intermediária da copa das árvores.

3.2.4.3. Determinação da concentração de nutrientes nos diferentes compartimentos das árvores

As mesmas amostras que já haviam sido usadas anteriormente para a umidade das folhas e dos ramos foram utilizadas para determinar a concentração de nutrientes nestes compartimentos. O tronco foi amostrado utilizando-se duas cunhas de madeira (em sentidos opostos), de igual tamanho, de cada um dos discos retirados das árvores nas diferentes alturas do tronco, como foi citado no item 3.2.4.2. Estes discos foram separados em lenho e casca. Cada uma das cunhas e cada um dos semi-anéis da casca foram fragmentadas separadamente. Todo o material também foi moído separadamente em moinho tipo Wiley e passado numa peneira de malha 20 e seco em estufa. Amostras do pó assim obtidas foram levadas ao laboratório para extração com uma mistura de ácidos sulfúrico, nítrico e perclórico; os elementos contidos nos extratos foram determinados por espectrofotometria de absorção atômica. Para a determinação dos elementos químicos de cada componente da árvore usou-se a metodologia de Sarruge \& Haag (1974). 
3.2.4.4. Determinação das equações para estimativa da biomassa arbórea

Objetivando determinar a biomassa dos componentes lenho, casca, ramos e folhas das árvores, por hectare, nas parcelas de E. saligna, foram testadas várias equações matemáticas correlacionando o peso de cada um desses componentes com as variáveis dendrométricas DAP e altura total, mensuradas nas 20 árvores (cinco árvores por parcela). Após a escolha do melhor modelo de equação matemática para cada componente, foi possível estimar o peso de biomassa de cada árvore amostrada.

Finalmente, aplicando-se as equações, obtidas a partir das 20 árvores amostrais, para os valores de $\mathrm{H}$ e DAP para as demais árvores nas parcelas, foi possível estimar a fitomassa arbórea total $\left(\mathrm{Kg}_{\mathrm{h}} \mathrm{ha}^{-1}\right)$ para cada componente das árvores (lenho, casca, ramos e folhas) e biomassa total.

\subsection{Estimativa da fitomassa arbórea acima do solo e da mineralomassa.}

Após a obtenção do peso de cada componente da biomassa arbórea e seu respectivo conteúdo médio de nutrientes, através da determinação da concentração de nutrientes nos diferentes compartimentos das árvores, conforme o ítem 3.2.4.3., foi possível estimar a quantidade dos nutrientes $\mathrm{N}, \mathrm{P}$, $\mathrm{Ca}, \mathrm{Mg}$ e $\mathrm{S}$ existentes na fitomassa arbórea de cada uma das parcelas em estudo.

A quantidade de cada um dos elementos estudados foi calculada multiplicando-se a biomassa de cada compartimento pela sua concentração elementar. 


\section{RESULTADOS E DISCUSSÃO}

\subsection{Aspectos hidrológicos \\ 4.1.1. Balanço hídrico}

A definição do ano hídrico e do balanço hídrico, em estudos hidrológicos, está entre as primeiras e mais importantes análises a serem feitas para se verificar a influência da cobertura florestal ou do uso do solo e o regime hidrológico de uma bacia hidrográfica.

O deflúvio pode ser considerado como a interação de todos os fatores hidrológicos em uma bacia hidrográfica, incluindo características topográficas, clima, solo, geologia e o uso do solo (vegetação e atuação antrópica) (Lima, 1986). Do ponto de vista hidrológico, o deflúvio de uma bacia hidrográfica pode ser considerado como sendo o produto residual do ciclo hidrológico, o qual é influenciado por três grandes grupos de fatores: clima, fisiografia e uso do solo.

A Figura 7 apresenta os valores médios anuais de deflúvio (Q)(mm) na microbacia A para o período de junho de 1987 a maio de 1995 e B para o período junho de 1987 a maio de 1994. É observado, para ambas microbacias, uma tendência de diminuição do deflúvio com o crescimento do povoamento florestal, assim como o aumento do deflúvio da microbacia A no primeiro ano após o corte raso da plantação de E. saligna. Este resultado está de acordo com resultados de estudos similares, tais como os encontrados por Feller \& Kimmis (1984), Bruijnzeel (1990), Brooks et al. (1991) e Fahey (1994). A microbacia $\mathrm{B}$ apresentou um deflúvio mais elevado que a microbacia $\mathrm{A}$. 


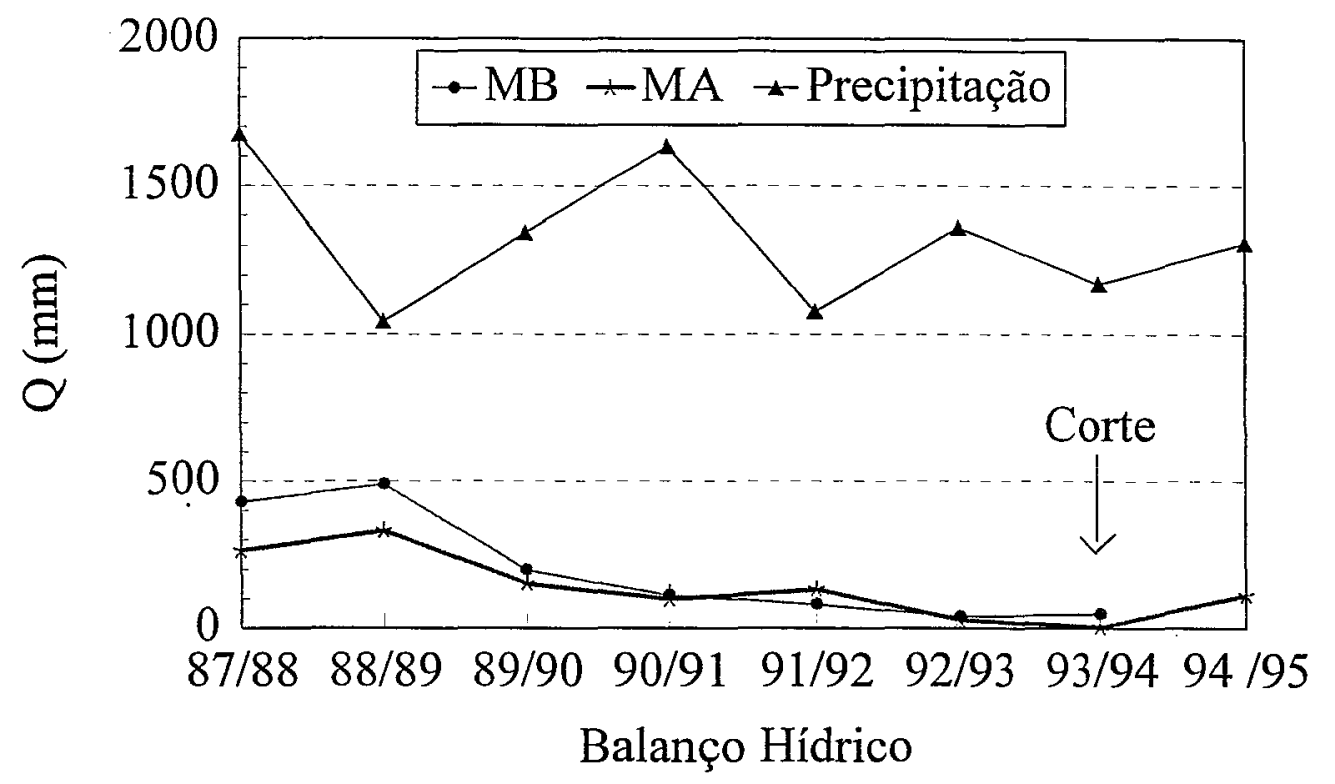

Figura 7. Valores Médios anuais do deflúvio nas microbacias A (Periodo: jun/87 a mai/95) e B (Período: jun/87/ mai/94).

Lima (1993) ${ }^{1}$, após uma extensa revisão sobre impacto hidrológico do eucalipto, conclui que os dados disponíveis apresentam uma clara evidência de que as plantações de eucalipto, no que se diz respeito ao balanço hídrico de bacias hidrográficas, não diferem de outras espécies florestais, apresentando aumento médio do deflúvio devido ao corte da floresta e, diminuição média do deflúvio devido o reflorestamento da bacia, da mesma magnitude de resultados similares obtidos com outras espécies florestais.

Poore \& Fries (1985) e Lima (1995) reafirmam que na fase de crescimento inicial, a exemplo do que ocorre com muitas espécies, é que as plantações de eucalipto demandam maiores quantidades de água. Isto pode ser constatado por Waterloo (1994), avaliando o impacto do reflorestamento com Pinus em Fiji, quando encontrou que a evapotranspiração foi mais alta (92\% da

\footnotetext{
${ }^{1}$ Lima, W.P. Efeitos hidrológicos do reflorestamento em eucalipto: relatório global do período junho 1987 a junho 1993. 199p. (Relatório Interno - IPEF).
} 
precipitação anual) na fase de rápido crescimento da floresta (Tabela 1), e mais baixa na floresta madura danificada por ciclone ( $82 \%$ da precipitação anual).

A Figura 8 mostra uma representação esquemática do balanço hídrico para as microbacia A e B, sendo $\mathrm{P}$ a precipitação, ET a evapotranspiração, e Q o deflúvio. 


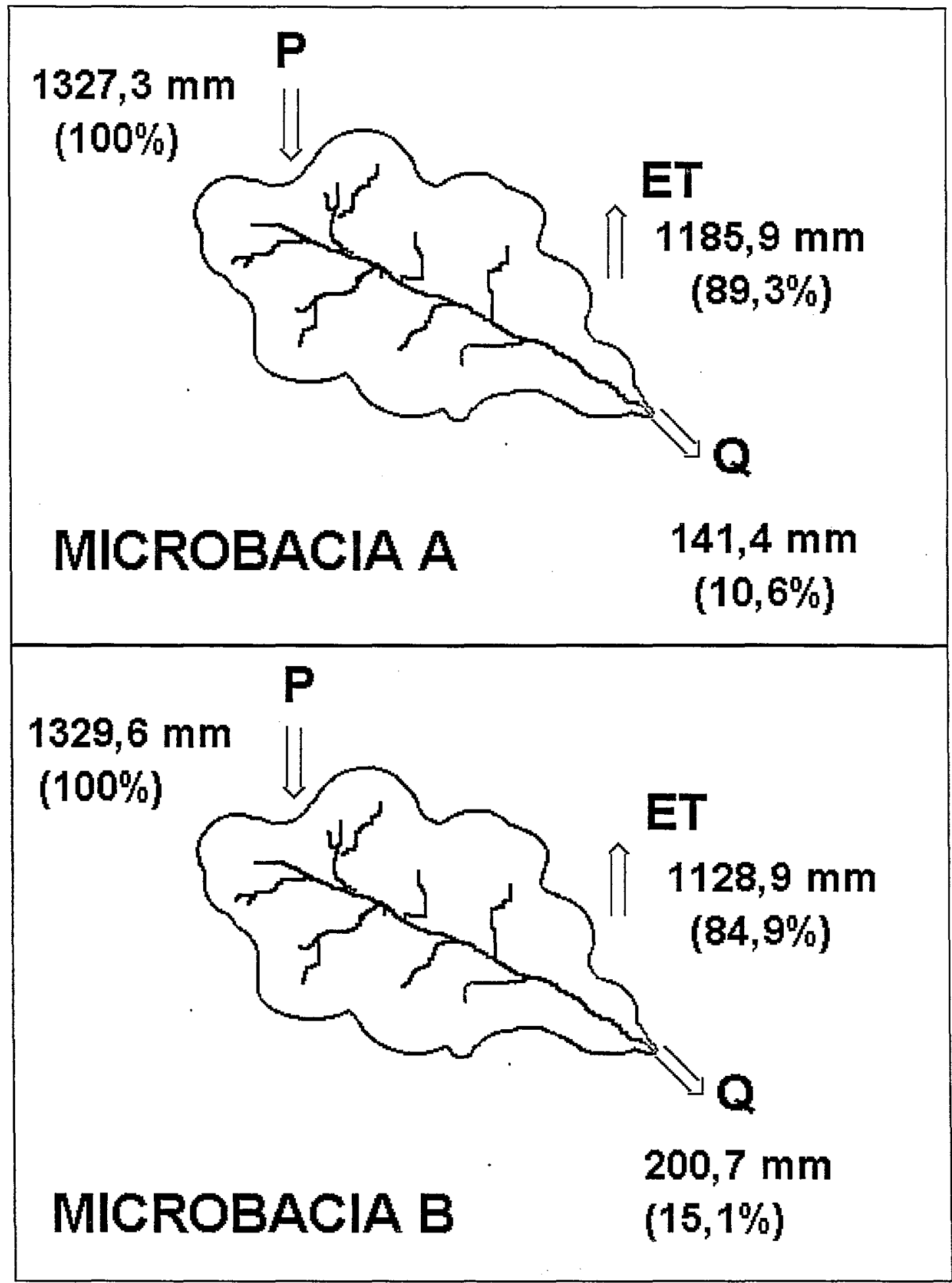

Figura 08. Representação esquemática do balanço hídrico (valores médios anuais) para as microbacias A (Período: jun/87 a mai/95) e B (Período: jun/87 a mai/94), sendo P precipitação, ET evapotranspiração e Q o deflúvio. 
A relação vazão/precipitação foi de $10,6 \%$ para a microbacia A, no período junho de 1987 a maio de 1995 e 15,1\% na microbacia B, para o período junho de 1987 a maio de 1994. De acordo com a equação básica do balanço hídrico para uma bacia, $P-E T-Q-\Delta S=0$, pela diferença entre a precipitação e o deflúvio e considerando-se a variação de armazenamento de água no solo $(\Delta S)$ igual a zero, a evapotranspiração para o período estudado foi estimada em $89,3 \%$ para a microbacia A e $84,9 \%$ para a microbacia B (Figura 8). Estes valores estão bem próximos dos encontrados por Waterloo (1994) para uma microbacia reflorestada com Pinus em Fiji, onde a relação vazão/precipitação foi em média $16 \%$ e a evapotranspiração em $83 \%$.

Bruijnzeel (1990), revisando o balanço hídrico para áreas florestais tropicais, encontrou, em média, uma evapotranspiração em torno de $47,8 \%$ da precipitação anual. Também próximo do valor encontrado por Leopoldo et al. (1982) para floresta de terra firme na Amazônia, que foi de 48,5\%.

A relação vazão/precipitação é ligeiramente maior na microbacia $B$ do que na microbacia $A$. Esta tendência pode ser observada em quase todos os meses dos 7 primeiros anos do período experimental (Figura 7). Esta diferença pode ser explicada, em parte, pela caracteristica de impermeabilidade do solo na microbacia $B$, a qual apresenta um gradiente textural acentuado $(24,7 \%$ de argila no horizonte A contra $40,9 \%$ no horizonte B) (Apêndice 1 ) possuindo também uma maior declividade, fatores esses que são favoráveis a uma menor tempo de residência da água nesta microbacia, favorecendo um escoamento superficial maior devido a redução da velocidade de infiltração do horizonte A para o B.

$\mathrm{Na}$ Tabela 1, cujos dados são oriundos do trabalho de Lima et al. (1996), pode-se observar o balanço hídrico comparativo entre microbacias 
contendo diferentes coberturas vegetais. Os valores encontrados no presente estudo*, portanto, apresentam valores aproximados daqueles observados, com relação a diferentes plantações florestais, em diferentes regiões climáticas.

Pode-se observar, nesta tabela, que o consumo anual de água pela plantação de eucalipto na microbacia estudada encontra-se dentro da faixa de variação observada com outras espécies florestais. 
Tabela 1. Balanço hídrico comparativo de microbacias contendo diferentes coberturas vegetais, incluindo campo, savana, florestas latifoliadas de clima temperado, coníferas de clima temperado, florestas tropicais e plantações florestais (Adaptado de Lima et al. 1996).

\begin{tabular}{|l|l|c|c|c|}
\hline VEGETAÇÃO & LOCAL & P & $\begin{array}{c}\text { Q } \\
\text { (mm/ano) }\end{array}$ & ET \\
\hline CAMPO & África do Sul & 1400 & 650 & 750 \\
& Reino Unido & 2348 & 1944 & 405 \\
SAVANA & Arizona, USA & 549 & 34 & 515 \\
& Califórnia, USA & 648 & 64 & 584 \\
& África do Sul & 1390 & 590 & 800 \\
LATIFOLIADAS & Georgia, USA & 1219 & 467 & 752 \\
& West Virgínia, USA & 1524 & 584 & 940 \\
CONÍFERAS & Japão & 1113 & 290 & 823 \\
& Oregon, USA & 2730 & 1750 & 980 \\
FLORESTAS & Quênia & 1905 & 416 & 1489 \\
TROPICAIS & Malasia & 2156 & 1076 & 1079 \\
& Amazônia & 2089 & 541 & 1548 \\
PLANTAÇÕES & & & & \\
FLORESTAIS & & & & \\
Pinus sylvestrys & Reino Unido & 2181 & 1325 & 856 \\
Pinus patula & Quênia & 2598 & 1540 & 1038 \\
Agathis dammara & Indonésia & 4668 & 3460 & 1217 \\
Pinus caribaea & Fiji & 1547 & 246 & 1301 \\
Eucalyptus globulus & Portugal & 837 & 8 & 828 \\
*Eucalyptus saligna & Brasil & 1329 & 145 & 1184 \\
\hline
\end{tabular}

\subsection{Qualidade da água}

\subsubsection{Parâmetros químicos}

O estudo da influência da floresta sobre a qualidade da água é, atualmente, parte importante em estudos florestais. A qualidade da água, por sua vez, deve ser definida em termos de suas características físicas, químicas e biológicas (Lima, 
1986). A descrição quantitativa destas características é feita através dos parâmetros de qualidade da água.

As Tabelas 2 e 3 mostram as concentrações médias mensais e anuais de $\mathrm{NO}_{3}^{-}, \mathrm{K}^{+}, \mathrm{Ca}^{++}, \mathrm{Mg}^{++}, \mathrm{Fe}^{++} \mathrm{e} \mathrm{Na}^{+}$das amostras de água da chuva e do deflúvio das duas etapas que marcaram o período amostral, antes e pós corte, respectivamente.

Verifica-se uma grande variabilidade na concentração dos nutrientes na água da precipitação e do deflúvio para o período de crescimento da plantação de eucalipto.

Quanto ao conteúdo mineral da água da chuva, estas variações se devem às influências atmosféricas (distância do mar, contaminação pela poeira, da diluição na atmosfera e outros fatores), resultando em uma diferença de valores no decorrer do ano (Golley et al. 1978). 
Tabela 2 - Concentrações médias mensais de $\mathrm{NO}_{3}^{-}, \mathrm{K}^{+}, \mathrm{Ca}^{++}, \mathrm{Mg}^{++}, \mathrm{Fe}^{++}$, e Na ${ }^{+}$na água da chuva (Prec) e na água do deflúvio da microbacia $\mathrm{A}$ (DFA) e da microbacia B (DFB) (Período: junho de 1987 a maio de 1994).

Nutrientes(mg/l)

\begin{tabular}{|c|c|c|c|c|c|c|c|}
\hline Mês & Local & $\mathrm{NO}_{3}^{-}$ & $\mathbf{K}^{+}$ & $\mathrm{Ca}^{\mathrm{T}}$ & $\mathrm{Mg}^{\mathrm{ft}}$ & $\mathrm{Fe}^{++}$ & $\mathrm{Na}^{+}$ \\
\hline \multirow{3}{*}{$\mathbf{J U N}$} & Prec & 0.45 & 0.12 & 0.27 & 0.03 & 0.14 & 0.37 \\
\hline & DFA & 0.39 & 1.54 & 2.10 & 0.54 & 1.96 & 2.48 \\
\hline & DFB & 0.55 & 1.69 & 1.41 & 0.63 & 0.81 & 2.51 \\
\hline \multirow{3}{*}{ JUL } & Prec & 0.58 & 0.67 & 1.05 & 0.24 & 0.01 & 1.26 \\
\hline & DFA & 0.28 & 1.49 & 2.37 & 0.56 & 1.70 & 2.67 \\
\hline & DFB & 0.38 & 1.52 & 1.51 & 0.61 & 0.55 & 2.46 \\
\hline \multirow{3}{*}{ AGO } & Prec & 1.10 & 0.46 & 0.90 & 0.21 & 0.07 & 0.92 \\
\hline & DFA & 0.27 & 1.33 & 2.22 & 0.54 & 1.28 & 2.35 \\
\hline & DFB & 0.33 & 1.30 & 1.45 & 0.55 & 0.46 & 2.22 \\
\hline \multirow{3}{*}{ SET } & Prec & 1.63 & 0.44 & 0.75 & 0.19 & 0.10 & 0.78 \\
\hline & DFA & 0.53 & 1.80 & 2.48 & 0.59 & 1.85 & 2.68 \\
\hline & DFB & 0.47 & 1.57 & 1.47 & 0.63 & 0.77 & 2.44 \\
\hline \multirow{3}{*}{ OUT } & Prec & 0.95 & 0.39 & 0.73 & 0.16 & 0.28 & 0.69 \\
\hline & DFA & 0.54 & 1.89 & 2.83 & 0.66 & 2.51 & 2.34 \\
\hline & DFB & 0.64 & 1.74 & 1.53 & 0.75 & 0.92 & 2.47 \\
\hline \multirow{3}{*}{ NOV } & Prec & 1.15 & 0.20 & 0.41 & 0.11 & 0.08 & 0.38 \\
\hline & DFA & 0.63 & 2.22 & 2.77 & 0.70 & 2.39 & 2.77 \\
\hline & DFB & 0.61 & 1.73 & 1.56 & 0.78 & 0.60 & 2.69 \\
\hline \multirow{3}{*}{ DEZ } & Prec & 0.79 & 0.54 & 0.32 & 0.09 & 0.16 & 0.39 \\
\hline & DFA & 0.61 & 2.59 & 2.79 & 0.67 & 2.27 & 2.58 \\
\hline & DFB & 0.56 & 2.07 & 1.58 & 0.78 & 0.63 & 2.50 \\
\hline \multirow{3}{*}{ JAN } & Prec & 0.91 & 0.20 & 0.24 & 0.06 & 0.05 & 0.25 \\
\hline & DFA & 1.23 & 2.72 & 3.04 & 0.71 & 3.02 & 2.29 \\
\hline & DFB & 0.67 & 1.79 & 1.64 & 0.73 & 0.72 & 2.40 \\
\hline \multirow{3}{*}{ FEV } & Prec & 0.33 & 0.24 & 0.24 & 0.05 & 0.16 & 0.21 \\
\hline & DFA & 0.59 & 2.78 & 3.05 & 0.69 & 3.53 & 2.32 \\
\hline & DFB & 0.68 & 1.98 & 1.71 & 0.76 & 0.77 & 2.36 \\
\hline \multirow{3}{*}{ MAR } & Prec & 0.41 & 0.18 & 0.17 & 0.04 & 0.08 & 0.11 \\
\hline & DFA & 0.58 & 2.31 & 2.76 & 0.67 & 2.11 & 2.22 \\
\hline & DFB & 0.80 & 1.80 & 1.63 & 0.77 & 0.55 & 2.10 \\
\hline \multirow{3}{*}{ ABR } & Prec & 0.52 & 0.19 & 0.44 & 0.13 & 0.10 & 0.36 \\
\hline & DFA & 0.58 & 1.86 & 2.42 & 0.65 & 1.96 & 2.34 \\
\hline & DFB & 0.76 & 1.92 & 1.88 & 0.78 & 0.89 & 2.45 \\
\hline \multirow{3}{*}{ MAI } & Prec & 0.40 & 0.22 & 0.46 & 0.13 & 0.05 & 0.41 \\
\hline & DFA & 0.63 & 1.65 & 2.55 & 0.67 & 2.52 & 2.44 \\
\hline & DFB & 0.65 & 2.01 & 1.87 & 0.79 & 0.75 & 2.75 \\
\hline \multirow{3}{*}{ Med. Anual } & Prec. & 0.77 & 0.32 & 0.50 & 0.12 & 0.11 & 0.51 \\
\hline & DFA & 0.57 & 2.02 & 2.61 & 0.64 & 2.26 & 2.46 \\
\hline & DFB & 0.59 & 1.76 & 1.61 & 0.71 & 0.70 & 2.45 \\
\hline
\end{tabular}


Tabela 3 - Concentrações médias mensais de $\mathrm{NO}_{3}^{-}, \mathrm{K}^{+}, \mathrm{Ca}^{++}, \mathrm{Mg}^{++}, \mathrm{Fe}^{++}, \mathrm{e} \mathrm{Na}^{+}$na água da chuva (Prec) e na água do deflúvio da microbacia $\mathrm{A}$, após o corte raso do eucalipto (DFA) (Período: junho de 1994 a maio de 1995).

\begin{tabular}{|c|c|c|c|c|c|c|c|}
\hline \multicolumn{8}{|c|}{ Nutriente(mg/l) } \\
\hline Mês & Local & $\mathrm{NO}_{3}^{-}$ & $\mathbf{K}^{+}$ & $\mathrm{Ca}^{+f}$ & $\mathbf{M g}^{\text {ff }}$ & $\mathrm{Fe}^{++}$ & $\mathrm{Na}^{+}$ \\
\hline & Prec & 0.10 & 0.40 & 1.94 & 0.51 & 0.00 & 0.30 \\
\hline JUN & DFA & 0.37 & 1.28 & 3.94 & 0.97 & 1.63 & 1.90 \\
\hline & Prec & 0.05 & 0.60 & 1.07 & 0.38 & 0.13 & 0.85 \\
\hline JUL & DFA & 0.16 & 1.59 & 3.32 & 0.69 & 1.60 & 1.88 \\
\hline AGO & $\begin{array}{l}\text { Prec } \\
\text { DFA }\end{array}$ & 0.30 & 1.70 & 3.13 & 0.78 & 0.58 & 2.36 \\
\hline SET & $\begin{array}{l}\text { Prec } \\
\text { DFA }\end{array}$ & 0.42 & 0.50 & 3.50 & 0.69 & 2.79 & 1.54 \\
\hline OUT & $\begin{array}{l}\text { Prec } \\
\text { DFA }\end{array}$ & $\begin{array}{l}1.02 \\
0.51\end{array}$ & $\begin{array}{l}2.70 \\
0.65\end{array}$ & $\begin{array}{l}6.32 \\
3.85\end{array}$ & $\begin{array}{l}2.19 \\
0.79\end{array}$ & $\begin{array}{l}0.38 \\
4.47\end{array}$ & $\begin{array}{l}1.75 \\
0.88\end{array}$ \\
\hline NOV & $\begin{array}{l}\text { Prec } \\
\text { DFA } \\
\end{array}$ & $\begin{array}{l}1.60 \\
1.30 \\
\end{array}$ & $\begin{array}{l}0.38 \\
2.24 \\
\end{array}$ & $\begin{array}{l}0.58 \\
4.23\end{array}$ & $\begin{array}{l}0.15 \\
0.83\end{array}$ & $\begin{array}{l}0.05 \\
2.55\end{array}$ & $\begin{array}{l}0.36 \\
3.16\end{array}$ \\
\hline DEZ & $\begin{array}{l}\text { Prec } \\
\text { DFA } \\
\end{array}$ & $\begin{array}{l}1.26 \\
1.35 \\
\end{array}$ & $\begin{array}{l}0.18 \\
1.58 \\
\end{array}$ & $\begin{array}{l}0.38 \\
3.35 \\
\end{array}$ & $\begin{array}{l}0.03 \\
0.72 \\
\end{array}$ & $\begin{array}{l}0.00 \\
2.38 \\
\end{array}$ & $\begin{array}{l}0.23 \\
2.75 \\
\end{array}$ \\
\hline JAN & $\begin{array}{l}\text { Prec } \\
\text { DFA } \\
\end{array}$ & $\begin{array}{l}0.73 \\
1.72 \\
\end{array}$ & $\begin{array}{l}0.14 \\
4.50 \\
\end{array}$ & $\begin{array}{l}0.23 \\
5.04 \\
\end{array}$ & $\begin{array}{l}0.05 \\
1.13 \\
\end{array}$ & $\begin{array}{l}0.03 \\
5.82\end{array}$ & $\begin{array}{l}0.16 \\
2.33\end{array}$ \\
\hline FEV & $\begin{array}{l}\text { Prec } \\
\text { DFA }\end{array}$ & $\begin{array}{l}0.28 \\
0.84\end{array}$ & $\begin{array}{l}0.13 \\
3.17\end{array}$ & $\begin{array}{l}0.17 \\
3.50\end{array}$ & $\begin{array}{l}0.00 \\
0.84\end{array}$ & $\begin{array}{l}0.00 \\
5.29\end{array}$ & $\begin{array}{l}0.17 \\
2.13 \\
\end{array}$ \\
\hline MAR & $\begin{array}{l}\text { Prec } \\
\text { DFA }\end{array}$ & $\begin{array}{l}0.61 \\
0.91 \\
\end{array}$ & $\begin{array}{l}0.45 \\
1.50 \\
\end{array}$ & $\begin{array}{l}0.44 \\
3.28 \\
\end{array}$ & $\begin{array}{l}0.16 \\
0.80 \\
\end{array}$ & $\begin{array}{l}0.32 \\
4.35\end{array}$ & $\begin{array}{l}0.43 \\
2.40 \\
\end{array}$ \\
\hline ABR & $\begin{array}{l}\text { Prec } \\
\text { DFA }\end{array}$ & $\begin{array}{l}1.23 \\
1.18 \\
\end{array}$ & $\begin{array}{l}0.48 \\
1.65 \\
\end{array}$ & $\begin{array}{l}0.19 \\
2.35\end{array}$ & $\begin{array}{l}0.13 \\
0.53 \\
\end{array}$ & $\begin{array}{l}0.13 \\
4.32\end{array}$ & $\begin{array}{l}0.23 \\
2.58 \\
\end{array}$ \\
\hline MAI & $\begin{array}{l}\text { Prec } \\
\text { DFA }\end{array}$ & $\begin{array}{l}0.13 \\
0.55 \\
\end{array}$ & $\begin{array}{l}0.10 \\
1.02 \\
\end{array}$ & $\begin{array}{l}0.33 \\
2.08 \\
\end{array}$ & $\begin{array}{l}0.09 \\
0.43 \\
\end{array}$ & $\begin{array}{l}0.00 \\
3.35 \\
\end{array}$ & $\begin{array}{l}0.20 \\
2.58 \\
\end{array}$ \\
\hline Méd. Anual & $\begin{array}{l}\text { Prec. } \\
\text { DFA }\end{array}$ & $\begin{array}{l}0.70 \\
0.80\end{array}$ & $\begin{array}{l}0.56 \\
1.78\end{array}$ & $\begin{array}{l}1.17 \\
3.46\end{array}$ & $\begin{array}{l}0.37 \\
0.76\end{array}$ & $\begin{array}{l}0.10 \\
3.26\end{array}$ & $\begin{array}{l}0.47 \\
2.21\end{array}$ \\
\hline
\end{tabular}


As Tabelas 2 e 3 mostram que, para $\mathrm{NO}_{3}^{-}$as concentrações médias anuais são maiores na água da chuva do que na do deflúvio para os períodos mais secos.

Aumento na concentração de $\mathrm{NO}_{3}{ }^{-}$foram observados por Dahlgren \& Driscoll (1994) na bacia experimental de Hubbard Brook, USA, no ano seguinte após o corte raso, alcançando seu valor máximo um ano após a exploração e vindo a se estabilizar 4 anos, aproximadamente após o corte.

O nitrato é altamente móvel. A remoção da vegetação, portanto, elimina o mecanismo de imobilização primária e permite a lixiviação. Por outro lado, a magnitude da perda de $\mathrm{N}$ por lixiviação pode estar associada com a abundância deste nutriente no reservatório do solo.

Para $\mathrm{K}^{+}, \mathrm{Ca}^{++}, \mathrm{Fe}^{++}$, e $\mathrm{Na}^{+}$, as concentrações médias se mostraram superiores na água do deflúvio da microbacia A e B, do que na água da chuva (Tabela 2). É observada uma tendência sazonal na química do deflúvio, com aumento na concentração dos nutrientes estudados durante o final da estação chuvosa. Estas concentrações encontram-se de acordo com os resultados encontrados por Guthrie et al. (1978), Hopmans (1987) e Malmer \& Grip (1994).

Com exceção do $\mathrm{NO}_{3}^{-}$e do $\mathrm{Mg}^{++}$, as concentrações dos nutrientes no deflúvio da microbacia $\mathrm{A}$, no período pré-corte, foram superiores aos da microbacia $\mathrm{B}$, evidenciando a ocorrência de uma maior interação da chuva com a vegetação e o solo daquela microbacia.

A Tabela 3 mostra que para o período pós corte as concentrações médias anuais para todos os nutrientes foram novamente inferiores na água da chuva do que na do deflúvio da microbacia A. Quando se compara esta microbacia (antes e pós tratamento), é claramente perceptível o aumento da 
concentração dos nutrientes $\mathrm{NO}_{3}^{-}, \mathrm{Ca}^{++}, \mathrm{Mg}^{++}$e $\mathrm{Fe}^{++}$na água do deflúvio, enquanto que $\mathrm{K}^{+} \mathrm{e} \mathrm{Na}^{+}$apresentam concentrações menores após o corte raso.

Significantes elevações do deflúvio e da concentração de nutrientes dissolvidos (nitidamente $\mathrm{NO}_{3}^{-}$e $\mathrm{K}^{+}$) têm sido observadas após a exploração seletiva em floresta na Malásia e Suriname (Bruijnzeel 1990; Stevens et al. 1995).

Stevens et al. (1995) verificaram que a concentração de $\mathrm{NO}_{3}^{-}$ nos canais que drenam as bacias exploradas foi mais elevado do que aqueles de bacias testemunhas durante 3 anos após o corte, retornando, posteriormente aos níveis anteriores.

\subsubsection{Parâmetros físicos}

As Figuras $9,10,11,12,13,14,15,16,17$, e 18, mostram a variação mensal do $\mathrm{pH}$, da alcalinidade; condutividade elétrica, cor e turbidez, parâmetros físicos de qualidade da água, comparativamente entre a precipitação e o deflúvio na microbacia $A$, entre os períodos pré-corte (junho de 87 - maio 94) e pós-corte (junho 94 - maio 95). 


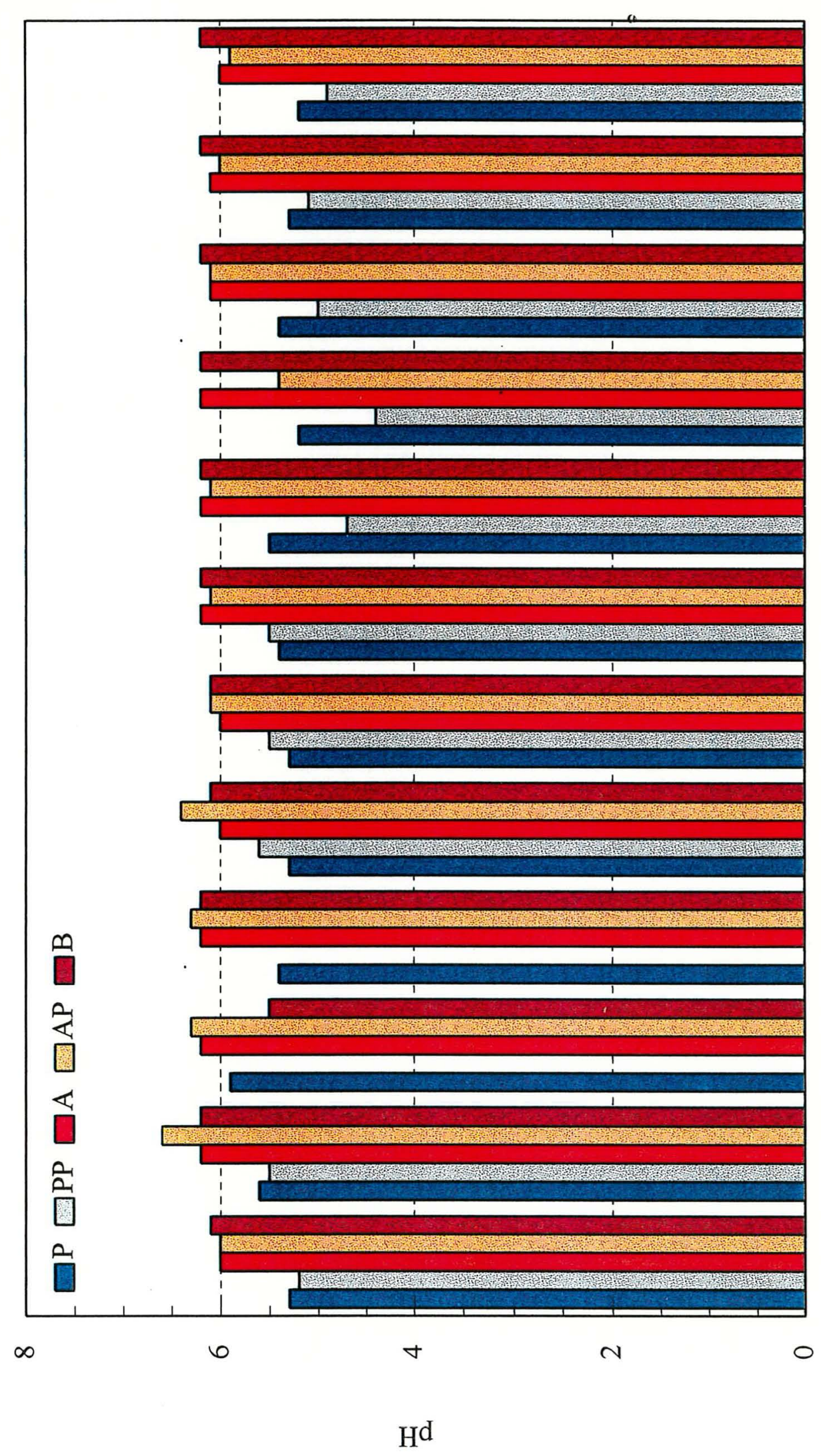

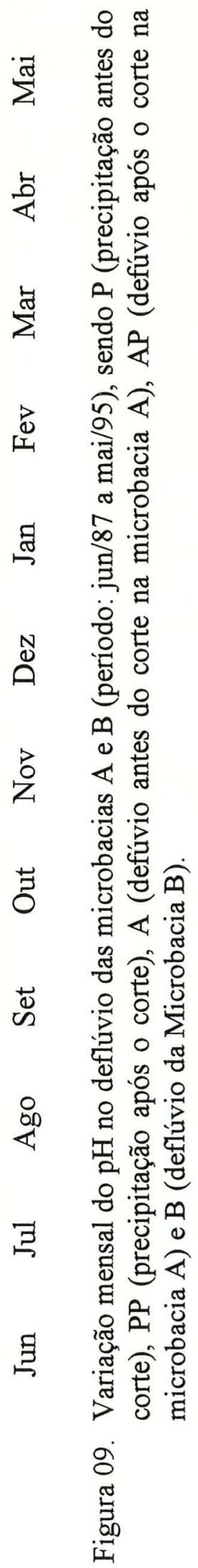




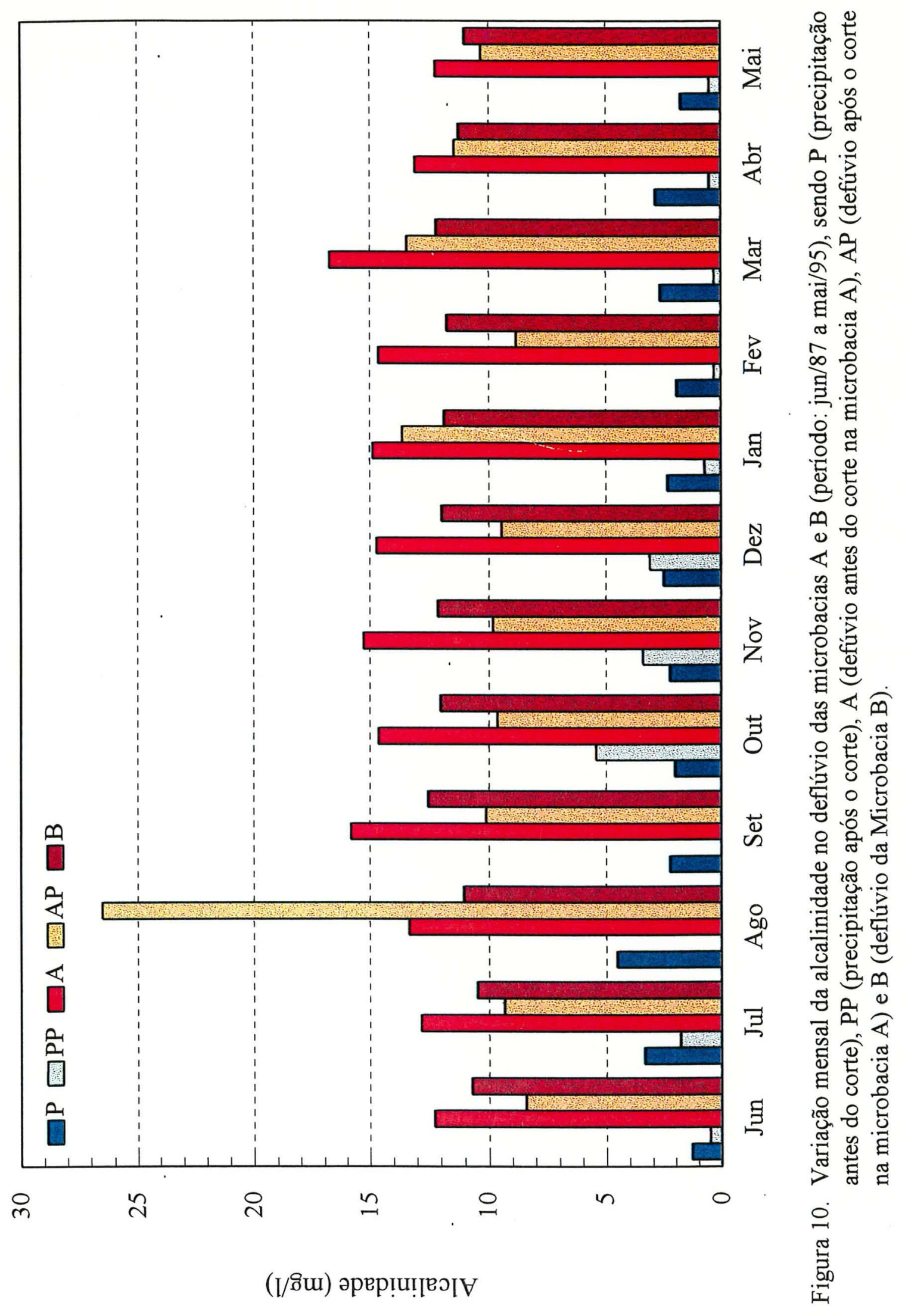




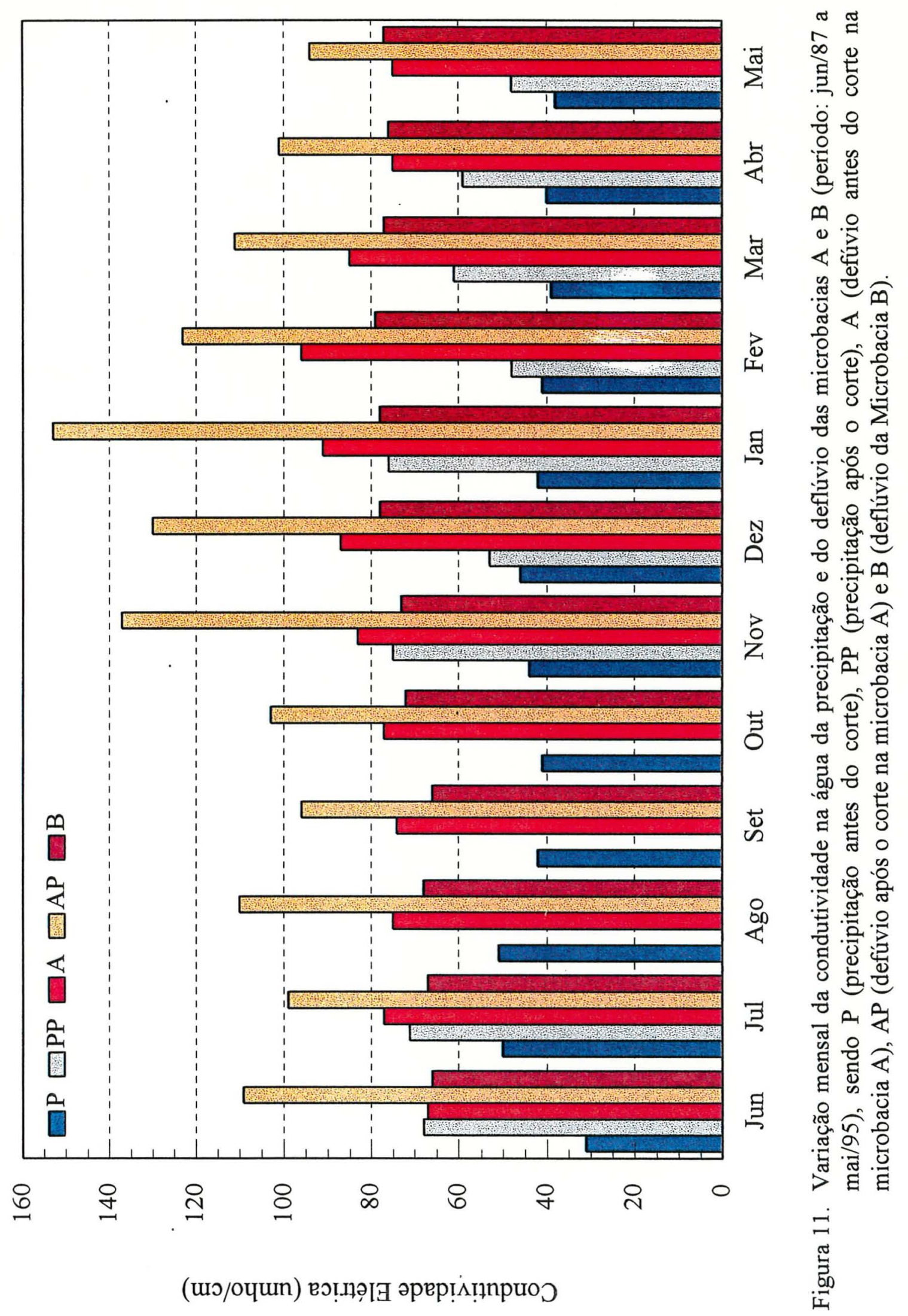




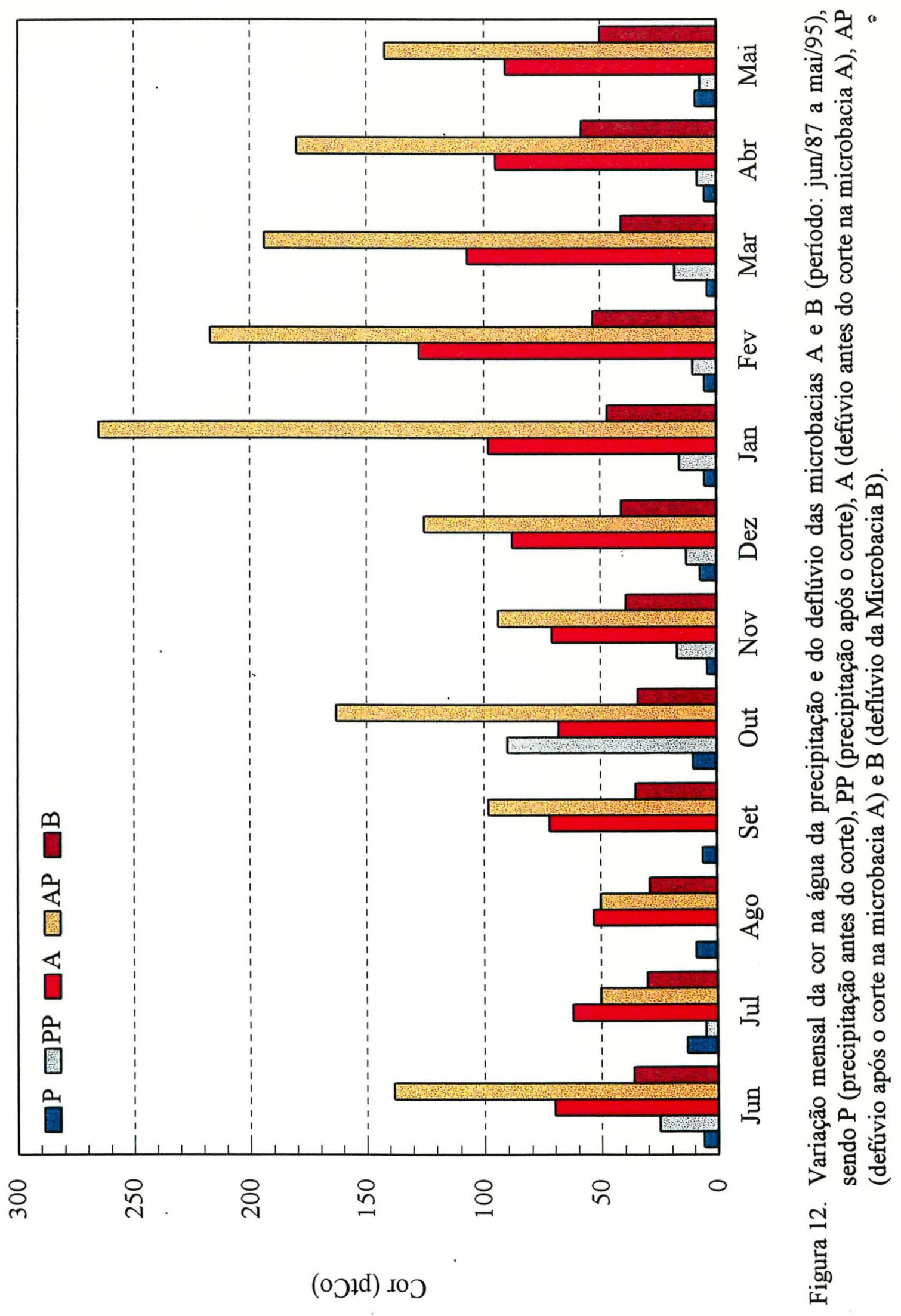




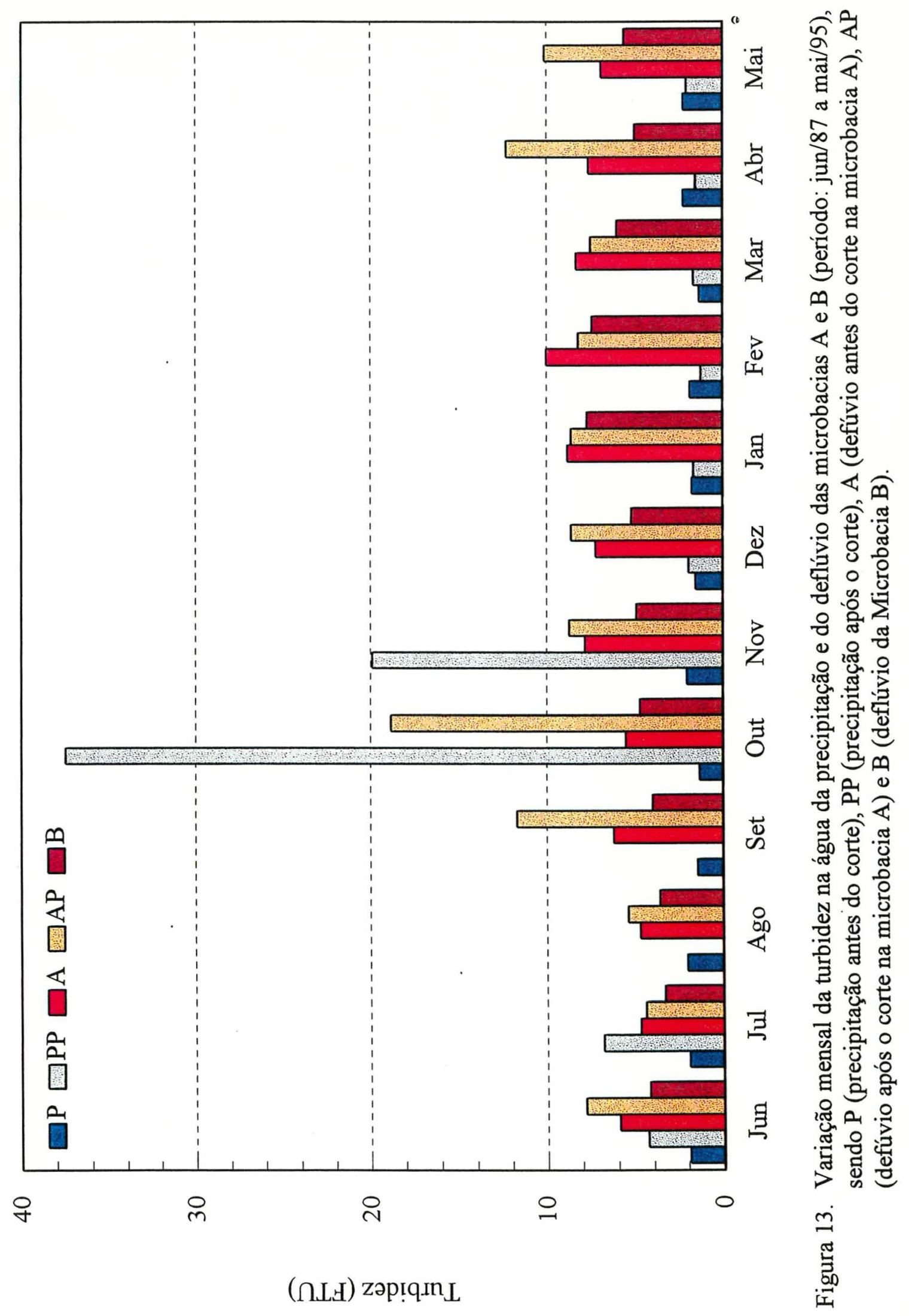


$\mathrm{O}$ pH e a alcalinidade sempre apresentaram valores médios menores na água da chuva do que no deflúvio. A água do deflúvio das microbacias A e B mativeram, basicamente, a mesma média.

A condutividade mostrou valores superior na microbacia $\mathrm{A}$, indicando uma maior concentração iônica nessa bacia. O mesmo comportamento foi verificado para os parâmetros cor e turbidez, os quais foram superiores na microbacia A do que os encontrados na microbacia $B$.

Em bacias com solos de baixa permeabilidade, onde predomina o escoamento superficial, a qualidade da água varia com a descarga. $\mathrm{O}$ mesmo não ocorre em bacias cujos solos apresentam alta permeabilidade com predomínio do escoamento subsuperficial, onde a qualidade da água não varia com a variação do deflúvio.

Comparando o comportamento da microbacia A para todo o período experimental, após o corte, observa-se um aumento no deflúvio para os parâmetros Cor (1,7 vezes maior), Turbidez (1,3 vezes maior) e Condutividade (1,4 vezes maior) em relação ao período anterior ao corte.

$\mathrm{O}$ aumento significativo da cor pode ser de origem mineral ou vegetal ou ainda por resíduos orgânicos (Batalha, 1977). Assim como a turbidez é atribuída as partículas sólidas em suspensão causada pelo arraste das partículas de solo, após a exposição da área explorada, como também pela presença de $\mathrm{Fe}^{++}$, resultantes do processo natural de erosão.

$\mathrm{O}$ pH da água da chuva manteve a mesma média e valores ainda menores aos observados antes do tratamento. Igualmente ocorreu com a alcalinidade. 
Quanto aos valores médios superiores encontrados na água da chuva para a condutividade, durante os meses mais secos do ano, proporcionam uma indicação de uma maior concentração de aerossóis na atmosfera.

A água da chuva apresentou valores mais elevados para a maior parte dos parâmetros físicos após o corte, principalmente para o mes de outubro, indicando um possível efeito da estiagem (maiores concentrações de aerossóis na atmosfera) que ocorreu neste último ano de amostragem. Observa-se a ausência de precipitação para os dois meses antecedentes (agosto e setembro). É coveniente lembrar que a comparação dos dados está sendo feita entre valores médios anuais para o período de 7 anos antes do corte, contra os valores obtidos no primeiro ano após o corte.

O primeiro ano após o corte apresentou dados atípicos para a precipitação, relativamente aos valores médios do período anterior ao corte. Infelizmente, a perda dos dados da microbacia $B$ não permitiu confrontá-la como testemunha, com o objetivo de verificar o efeito desse aumento (na microbacia A) e assim comparar as concentrações observadas no deflúvio para ambas microbacias.

Todavia, de um modo geral, a qualidade final da água do deflúvio é mais dependente de fatores intrínsecos da microbacia (geologia, solo, etc.), do que a fatores externos (Talsma \& Hallam, 1982).

\subsection{Balanço de Nutrientes}

As Tabelas 4, 5, 6, e 7 contém os resultados do balanço geoquímico médio anual para os nutrientes estudados, determinados pela diferença entre a entrada via precipitação e saída via água do deflúvio. 
Tabela 4. Valores médios anuais da densidade de fluxo $\left(\mathrm{kg}^{\mathrm{ha}} \mathrm{h}^{-1} \cdot \mathrm{ano}^{-1}\right)$ para os nutrientes $\mathrm{NO}_{3}^{-}, \mathrm{K}^{+}, \mathrm{Ca}^{++}, \mathrm{Mg}^{++}, \mathrm{Fe}^{++}, \mathrm{Na}^{+}$, na água da chuva (Prec) e na água do deflúvio da microbacia $\mathrm{A}$ (DFA) e da microbacia $\mathrm{B}$ (DFB) (Período: junho de 1987 a maio de 1994).

\begin{tabular}{|c|c|c|c|c|c|c|c|}
\hline & \multirow[t]{2}{*}{ Local } & \multicolumn{3}{|c|}{ Kg $\mathrm{ha}^{\mathrm{t}}$ ano } & \multirow[b]{2}{*}{$\mathrm{Mg}$} & \multirow[b]{2}{*}{$\mathrm{Fe}+$} & \multirow[b]{2}{*}{ Nar } \\
\hline & & $\mathrm{NO}_{3}$ & $\mathrm{~K}$ & $\mathrm{Ca}$ & & & \\
\hline \multirow{3}{*}{$\begin{array}{l}\text { Total } \\
\text { Anual }\end{array}$} & Prec. & 9,66 & 3,90 & 5,28 & 1,29 & 1,47 & 5,24 \\
\hline & DFA & $\mathbf{0 , 8 5}$ & 2,99 & 3,80 & $\mathbf{0 , 9 2}$ & 3,38 & 3,55 \\
\hline & DFB & 1,22 & 3,58 & 3,24 & 1,45 & 1,41 & 4,91 \\
\hline
\end{tabular}

Tabela 5. Valores médios anuais da densidade de fluxo $\left(\mathrm{kg} \cdot \mathrm{ha}^{-1} \cdot \mathrm{ano}^{-1}\right)$ para os nutrientes $\mathrm{NO}_{3}^{-}, \mathrm{K}^{+}, \mathrm{Ca}^{++}, \mathrm{Mg}^{++}, \mathrm{Fe}^{++}, \mathrm{Na}^{+}$, na água da chuva (Prec) e na água do deflúvio da microbacia $\mathrm{A}$ (DFA) e da microbacia $\mathrm{B}$ (DFB) (Período: junho de 1994 a maio de 1995).

\begin{tabular}{|c|c|c|c|c|c|c|c|}
\hline & \multirow[t]{2}{*}{ Local } & \multicolumn{5}{|c|}{ Kg.hat ano $^{-1}$} & \\
\hline & & $\mathrm{NO}_{3}$ & $\mathrm{~K}^{\top}$ & $\mathrm{Ca}^{+}$ & Mg & $\mathrm{Fe}$ & $\mathrm{Na}^{2}$ \\
\hline Total & Prec. & $\overline{9,74}$ & $\overline{4,96}$ & 9,59 & 2,83 & 1,04 & $\overline{4,41}$ \\
\hline Anual & DFA & $\mathbf{1 , 5 5}$ & $\mathbf{3 , 8 2}$ & 5,10 & 1,14 & 5,67 & 2,50 \\
\hline
\end{tabular}

Tabela 6. Balanço médio anual (S) $\left(\mathrm{kg}^{-h^{-1}}\right)$ de $\mathrm{NO}_{3}^{-}, \mathrm{K}^{+}, \mathrm{Ca}^{++}, \mathrm{Mg}^{++}, \mathrm{Fe}^{++}$e $\mathrm{Na}^{+}$, determinado pela entrada via água da chuva $\left(\mathrm{kg} \cdot \mathrm{ha}^{-1}\right)(\mathrm{P})$ e saída via deflúvio $\left(\mathrm{kg}_{\mathrm{h}} \mathrm{h}^{-1}\right)(\mathrm{Q})$ da microbacia A e da microbacia B (Período: junho de 1987 a maio de 1994).

\begin{tabular}{l|ccc|ccc}
\hline \multicolumn{1}{c|}{ Nutrientes } & \multicolumn{3}{c|}{ Microbacia A } & \multicolumn{4}{c}{ Microbacia B } \\
\hline & $\mathrm{P}$ & $\mathbf{Q}$ & $\mathrm{S}$ & $\mathrm{P}$ & $\mathbf{Q}$ & $\mathrm{S}$ \\
\hline \hline $\mathrm{NO}_{\mathbf{3}}^{-}$ & $\mathbf{9 , 6 6}$ & $\mathbf{0 , 8 5}$ & $\mathbf{8 , 8 1}$ & $\mathbf{9 , 6 6}$ & $\mathbf{1 , 2 2}$ & $\mathbf{8 , 4 4}$ \\
$\mathrm{K}^{+}$ & $\mathbf{3 , 9 0}$ & $\mathbf{2 , 9 9}$ & $\mathbf{0 , 9 1}$ & $\mathbf{3 , 9 0}$ & $\mathbf{1 , 1 5}$ & $\mathbf{2 , 7 5}$ \\
$\mathrm{Ca}^{++}$ & $\mathbf{5 , 2 8}$ & $\mathbf{3 , 8 0}$ & $\mathbf{1 , 4 7}$ & $\mathbf{5 , 2 8}$ & $\mathbf{3 , 2 4}$ & $\mathbf{2 , 0 4}$ \\
$\mathrm{Mg}^{++}$ & $\mathbf{1 , 2 9}$ & $\mathbf{0 , 9 2}$ & $\mathbf{0 , 3 7}$ & $\mathbf{1 , 2 9}$ & $\mathbf{1 , 4 5}$ & $\mathbf{- 0 , 1 6}$ \\
$\mathrm{Fe}^{++}$ & $\mathbf{1 , 4 7}$ & $\mathbf{3 , 3 8}$ & $\mathbf{- 1 , 9 1}$ & $\mathbf{1 , 4 7}$ & $\mathbf{1 , 4 1}$ & $\mathbf{0 , 0 6}$ \\
$\mathrm{Na}+$ & $\mathbf{5 , 2 4}$ & $\mathbf{3 , 5 5}$ & $\mathbf{1 , 6 9}$ & $\mathbf{5 , 2 4}$ & $\mathbf{4 , 9 1}$ & $\mathbf{0 , 3 3}$ \\
\hline
\end{tabular}


Tabela 7. Balanço médio anual (S) $\left(\mathrm{kg}^{-h a^{-1}}\right)$ de $\mathrm{NO}_{3}^{-}, \mathrm{K}^{+}, \mathrm{Ca}^{++}, \mathrm{Mg}^{++}, \mathrm{Fe}^{++}$e Na ${ }^{++}$, determinado pela entrada via água da chuva $\left(\mathrm{kg}_{\mathrm{h}} \mathrm{ha}^{-1}\right)(\mathrm{P})$ e saída via deflúvio (kg.ha ${ }^{-1}$ ) (Q) da microbacia A (Período: junho de 1994 a maio de 1995).

\begin{tabular}{|c|c|c|c|}
\hline Nutrientes & \multicolumn{3}{|c|}{ Microbacia A } \\
\hline 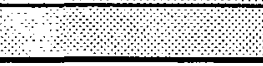 & P. & $Q$ & $\mathrm{~S}$ \\
\hline$\overline{\mathrm{NO}_{3}{ }^{-}}$ & $\overline{99,74}$ & $\overline{1,55}$ & $\overline{8,19}$ \\
\hline $\mathbf{K}^{+}$ & 4,96 & 3,82 & 1,14 \\
\hline $\mathrm{Ca}^{++}$ & 9,59 & 5,10 & 4,49 \\
\hline $\mathrm{Mg}^{++}$ & 2,83 & 1,14 & 1,70 \\
\hline $\mathrm{Fe}^{++}$ & 1,04 & 5,67 & $-4,63$ \\
\hline $\mathrm{Na}^{+}$ & 4,42 & 2,50 & 1,92 \\
\hline
\end{tabular}

Para o balanço médio anual dos nutrientes, os resultados mostram que existe um ganho de $\mathrm{NO}_{3}^{-}, \mathrm{K}^{+}, \mathrm{Ca}^{++}$e $\mathrm{Na}^{+}$para ambas as microbacias. Estes resultados são similares aos encontrados em outros trabalhos (Flinn et al. 1979; Guthrie et al. 1978). O balanço geoquímico foi negativo para $\mathrm{Fe}^{++}$na

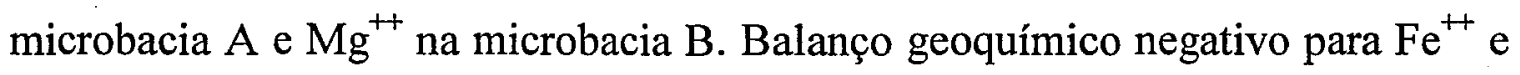
$\mathrm{Mg}^{++}$também foram encontrados por (Guthrie 1978; Golley et al. 1978; Arcova 1985; Ranzini 1990; Scardua 1994; Waterloo 1994), em estudos de microbacias hidrográficas. Estes resultados estão de acordo com o material de origem de tais microbacias: A, um solo mais intemperizado (recobrimento pleistocênico) (Apêndice 1) e B, solo mais recente, que corresponde ao material de origem predominante nesta bacia (serecito/xisto) (Apêndice 2).

Após o tratamento, a microbacia A continuou apresentando um balanço negativo para o $\mathrm{Fe}^{++}$.

Os aportes de $\mathrm{NO}_{3}^{-}, \mathrm{K}^{+}, \mathrm{Ca}^{++}$e $\mathrm{Mg}^{++}$foram mais elevados nesta segunda fase, com excessão do $\mathrm{Fe}^{++} \mathrm{e} \mathrm{Na}^{+}$, que se mostraram mais baixos. Porém, as saídas também apresentaram valores elevados, principalmente para $\mathrm{Ca}^{++} \mathrm{eFe}^{++}$. 


\subsubsection{Perdas de solo}

A erosão é a maior força desestabilizadora em ecossistemas perturbados, devido a perdas da regulação biológica, aumento da taxa de deposição, aumento da saída de partículas de matéria orgânica dissolvida e erosão dos nutrientes sob a influência da água da chuva, os quais, são alguma das maiores causas da degradação do ecossistema após a exploração florestal (Bargali \& Singh 1991).

A produção de sedimentos em suspensão foi maior na microbacia $\mathrm{B}$. Um dos motivos desta maior perda de solo está ligada à própria característica da bacia, que possui uma declividade maior, predominando o escoamento superficial e consequentemente, a lixiviação e arraste de solo para o curso d'água. Isto pode ser constatado quando se observa o hidrograma desta bacia, o qual, apresenta uma resposta mais rápida do deflúvio e um pico maior que o observado na microbacia A.

Como é bem conhecido, o transporte de sedimento anual ocorre durante um número limitado de eventos de alta pluviosidade.

Conforme mostra a Figura 14, após o tratamento, a microbacia A apresentou uma perda de solo de 41,5 Kg.ha ${ }^{-1}$ representando um valor 2,1 vezes maior, em comparação ao período antes do tratamento. Observa-se ainda que esta perda foi também maior que os valores encontrados por Ranzini (1990), que encontrou perdas da ordem de $30,7 \mathrm{~kg} \mathrm{ha}^{-1}$, na ocasião do preparo do solo (roçada, queimada, e aração à disco com $20 \mathrm{~cm}$ de profundidade), em estudo conduzido nesta mesma microbacia, praticamente no mesmo período de distribuição da precipitação anual.

Por outro lado, quando se compara estas perdas com as encontradas por Scardua (1994), $260 \mathrm{Kg} \cdot \mathrm{ha}^{-1} \cdot \mathrm{ano}^{-1}$ em plantações de Eucalyptus 
saligna no estado de São Paulo, os valores encontrados no presente estudo não representam perdas tão significativas.

De acordo com Neary \& Hornbeck (1994), somente a colheita florestal pode aumentar a taxa natural de erosão da ordem de 4 vezes mais, mas a construção de estradas na área de exploração pode elevar esta taxa em aproximadamente 120 vezes mais do que em floresta, mesmo em áreas declivosas não perturbadas.

As estradas mostram ter o efeito mais impactante no processo de colheita florestal. 


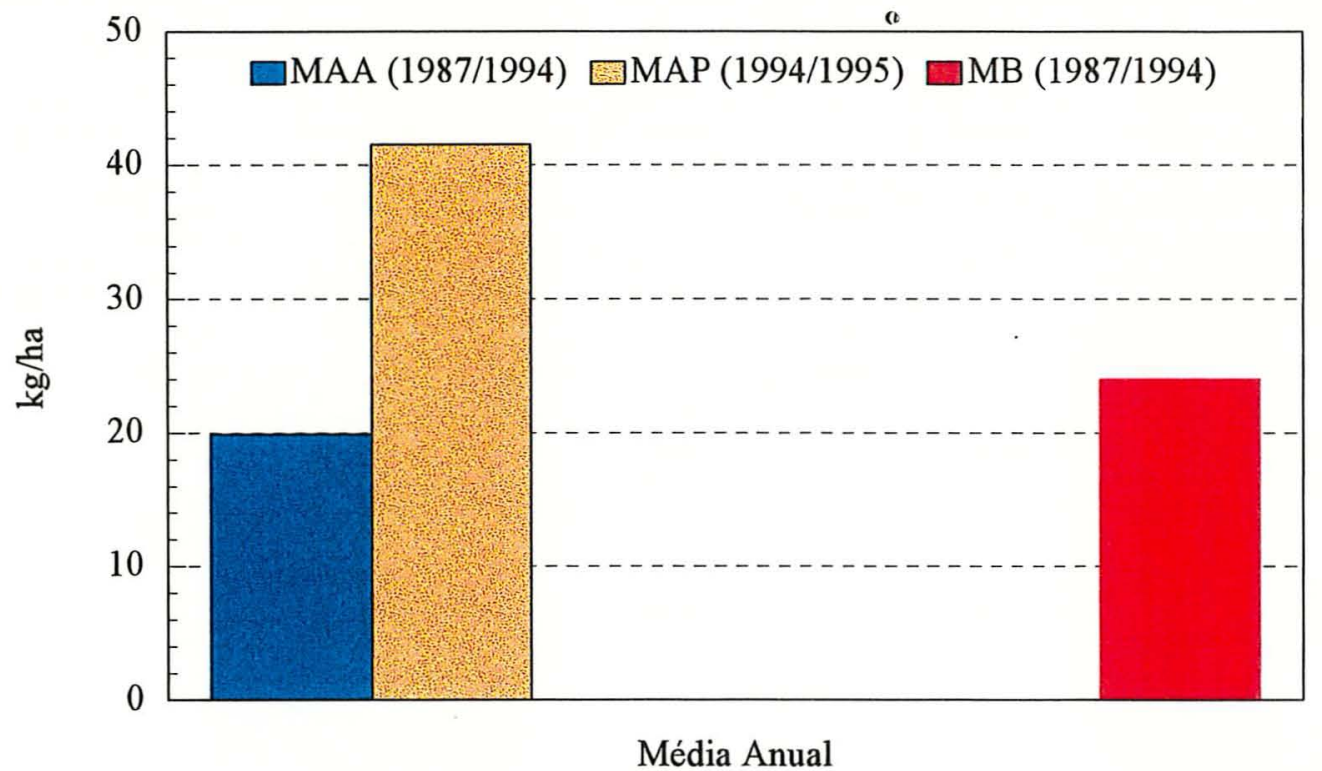

Figura 14. Média anual da perda de sedimento em suspensão $\left(\mathrm{Kg} \cdot \mathrm{ha}^{-1}\right)$ nas microbacias $\mathrm{A}$ antes do corte (MAA), microbacia A após o corte (MAP) e microbacia B (MB). Período antes do corte (jun/87 a mai/94), período após o corte (jun/94 a mai/95).

Visto que por ocasião do corte do Eucalyptus saligna foi utilizada a malha viária já existente na microbacia, as perdas aqui verificadas estão relacionadas apenas aos processos que envolveram a colheita, ou seja, a utilização de máquinas pesadas para o corte das árvores e transporte (sem arraste) do lenho para fins comerciais, ficando a área exposta mais suceptível ao arraste e lixiviação de partículas do solo.

É de se esperar que, de um modo geral, as perdas de nutrientes fossem mais elevadas após à colheita, caso não houvesse a permanência da mata ciliar na microbacia, a qual desenvolve importante papel na retenção e distribuição dos nutrientes que são lixiviados da área. A importância da mata ciliar, neste sentido, já foi comprovada, dentre outros autores, em trabalhos desenvolvidos por Lowrance et al. (1984) e Bruijnzeel (1990). 
4.4. Fitomassa arbórea e mineralomassa da parte aérea da plantação florestal da microbacia A

4.4.1. Fitomassa dos diferentes compartimentos das árvores

A Tabela 8 apresenta os resultados obtidos em função do inventário florestal nas parcelas amostrais da microbacia A, segundo metodologia descrita no item 3.2.4.1.

Tabela 8. Valores dendrométricos do reflorestamento com Eucalyptus saligna aos 7 anos de idade por ocasião da estimativa da biomassa.

\begin{tabular}{|c|c|c|c|c|c|}
\hline $\begin{array}{l}\text { Altura } \\
\text { Média } \\
(\mathrm{m})\end{array}$ & $\begin{array}{l}\text { DAP } \\
\text { Médio } \\
(\mathrm{cm})\end{array}$ & $\begin{array}{l}\text { Area Basal } \\
\left(\mathrm{m}^{2} / \mathrm{ha}\right)\end{array}$ & $\begin{array}{l}\text { N. de Arvores } \\
(\text { Parcela) }\end{array}$ & $\begin{array}{l}\text { N. de } \\
\text { árvores } \\
\text { portha }\end{array}$ & $\begin{array}{l}\text { Volume } \\
\text { (st/ha) }\end{array}$ \\
\hline 21,06 & 14,11 & 28,18 & 62 & 1.536 & 411,15 \\
\hline
\end{tabular}

A partir dos resultados obtidos no inventário florestal, foram estabelecidas 5 classes de diâmetro e escolhidas 4 árvores para cada classe. Após as árvores serem abatidas, seus compartimentos foram separados em lenho, casca, ramos e folhas. Cada um desses compartimentos teve sua matéria seca medida e através dos dados de inventário foi possível estimar a fitomassa total como mostra a Tabela 9.

Tabela 9. Fitomassa seca $\left(\mathrm{kg} \cdot \mathrm{ha}^{-1}\right)$ e (\%) do total em plantação de E. saligna aos 7 anos.

\begin{tabular}{cccccc}
$\begin{array}{c}\text { N. de } \\
\text { arvore/ha }\end{array}$ & Genho & Casca & Ramos & $\begin{array}{c}\text { Folhäs } \\
\mathbf{( \% )}\end{array}$ & $\begin{array}{c}\text { Fitomassa } \\
\text { Total }\end{array}$ \\
\hline \hline 1.536 & 145180,48 & 14657,40 & 13615,25 & 4616,18 & 178069,31 \\
& $(81,5)$ & $(8,2)$ & $(7,6)$ & $(2,6)$ & $(100)$ \\
\hline
\end{tabular}


Observa-se que o tronco (lenho+casca) representa $89,7 \%$ do total produzido, enquanto que a copa (ramos+folha) representa apenas $10 \%$ da fitomassa total. Estes valores concordam com as médias encontradas por Schumacher (1992) para três espécies de Eucalyptus: camadulensis, grandis e torelliana, com 9, 9, e 12 anos, respectivamente. Porém, com respeito à produção total de fitomassa (pêso seco), estes valores mostraram-se superiores aos encontrados por este autor.

O maior percentual de fitomassa produzido por um povoamento encontra-se nos troncos. Esta proporção tende a aumentar à medida que o povoamento envelhece (Andrade ${ }^{1}, 1976$, citado por Schumacher,1993)

4.4.2. Concentração dos nutrientes nos diferentes compartimentos das árvores

As diferentes concentrações de nutrientes encontradas nas espécies arbóreas florestais podem ser devido às condições climáticas onde as mesmas se desenvolvem, e ainda aliada a fatores genéticos próprios para cada espécie.

Tabela 10. Concentração de nutrientes nos diferentes componentes das árvores de Eucalyptus saligna Smith. aos 7 anos de idade.

\begin{tabular}{|c|c|c|c|c|c|c|}
\hline \multirow[b]{2}{*}{ Componente } & \multicolumn{6}{|c|}{ Nutrientes( $\%)$} \\
\hline & N & $\mathbf{P}$ & K. & $\mathrm{Ca}$ & Mg & S \\
\hline LENHO & 0,07 & $\overline{0,02}$ & 0,11 & $\overline{0,10}$ & $\overline{0,03}$ & 0,01 \\
\hline CASCA & 0,21 & 0,09 & 0,38 & 3,34 & 0,39 & 0,05 \\
\hline RAMOS & 0,19 & 0,04 & 0,34 & 0,90 & 0,15 & 0,02 \\
\hline FOLHAS & 0,92 & 0,11 & 1,01 & 0,84 & 0,26 & 0,13 \\
\hline
\end{tabular}

${ }^{1}$ Andrade, F.H. Washstum, wasser und nahrost fhaushalt von Araucaria angustifolia O. Kuntze, Cordia trichotoma Arrab und Eucalyptus saligna Smith Wien. Universität für Bodenkultur, 1976. $140 \mathrm{p}$. 
Verifica-se na Tabela 10 que as folhas possuem a maior concentração de nitrogênio $(\mathrm{N})$, fósforo $(\mathrm{P})$, potássio $(\mathrm{K})$, e enxôfre $(\mathrm{S})$; na casca foram encontradas as maiores concentrações de cálcio (Ca) e magnésio $(\mathrm{Mg})$.

Fato semelhante foi observado por Schumacher (1992), no Brasil, em plantações florestais onde encontrou uma concentracão de 1.990, $1.398,1.576 \% \mathrm{~N} ; 0.122,0.086,0.086 \% \mathrm{P} ; 1.380,0.976,1.300 \% \mathrm{~K} ; 0.746,0.746$, $0.568 \% \mathrm{Ca}$ e $0.188,0.230,0.176 \% \mathrm{Mg}$ para E. camadulensis E. grandis e E. torelliana, respectivamente, para folhas, ramos, casca e lenho. Também observou a máxima concentração de $\mathrm{Ca}$, apresentando um valor de $3.34 \%$ para o E. saligna, visivelmente mais elevado que os valores de $1.87 \mathrm{E}$. camadulensis; $1.46 \mathrm{E}$. grandis e $2.78 \%$ E. torelliana por este mesmo autor.

Poggiani (1985), também trabalhando com E. saligna, plantado sobre solo de baixa fertilidade, e coletando o material no final do período seco, observou que as maiores concentrações de $\mathrm{Ca}$ e Mg estavam na casca, sendo que para o elemento $\mathrm{Ca}$, ele encontrou valores superiores ao encontrado neste trabalho e valores menores para $\mathrm{Mg}$.

A elevada quantidade do elemento cálcio encontrado neste estudo para o E. saligna indica que esta espécie é bastante exigente com relação a este elemento.

Observou-se que o lenho do tronco representa $81,5 \%$ da fitomassa, mas apresenta uma proporção relativamente baixa de elementos minerais quando comparado com a casca, ramos e folhas.

Porém, verifica-se que o lenho+casca juntos representam $89,7 \%$ da fitomassa e esta representa uma alta proporção de elementos minerais, principalmente $\mathrm{Ca}$ e $\mathrm{Mg}$, do total de nutrientes da árvore como um todo. No caso 
de exploração florestal, principalmente o Ca demonstra ser um elemento crítico para perdas na ciclagem geoquímica dos nutrientes, ainda nesta primeira rotação. Uma reposição deste estoque de nutrientes no solo para este elemento poderá ser através da calagem (comumente utilizado em plantações florestais em solos pobres) e/ou ainda com a utilização de cinzas.

Por exemplo, Moro (1994), em pesquisa sobre os efeitos da cinza proveniente de biomassa florestal - sobre as características físicas e químicas do solo e, nutrição mineral de Eucalyptus grandis no município de Casa Branca-SP - encontrou que a aplicação de diferentes doses de cinza resultou em elevação de produtividade, independentemente das doses aplicadas, as quais foram superiores aos resultados conseguidos mediante a aplicação de adubo químico, equivalentes às que são utilizadas normalmente em plantios. Concluiu ainda que ficou evidente o papel da cinza como agente melhorador de atributos químicos do solo, consequentemente como fonte de nutrientes essenciais às árvores, devido estas influenciarem significativamente na concentração e no conteúdo de macronutrientes locados nos diversos compartimentos das árvores.

Por outro lado, Poggiani et al. (1983) recomendam que dentro do possível a devolução das cinzas às florestas é uma solução que deve ser sempre incentivada, face ao elevado teor de potássio, cálcio, magnésio e outros nutrientes que elas contêm.

De posse dos dados das concentrações de nutrientes nos diferentes componentes das árvores de Eucalyptus saligna (Tabela 10), a equação ajustada para a biomassa do lenho foi a que apresentou maior coeficiente de determinação, já a equação de biomassa de folhas obteve um menor valor. No primeiro caso, isto revela um melhor ajuste dos dados de DAP e altura total, 
relativamente ao modelo testado, o que indica uma melhor precisão das estimativas deste componente.

As equações obtidas foram:

Biomassa do Lenho $=\operatorname{EXP}(-7,20045+1,19926 \ln (\mathrm{D})+2,63666 \ln (\mathrm{H})) \mathrm{R}^{2}=0,993$

Biomassa da casca $=\operatorname{EXP}(-7,44801+1,05846 \ln (\mathrm{D})+2,14087 \ln (\mathrm{H})) \mathrm{R}^{2}=0,951$

Biomassa dos Ramos $=\operatorname{EXP}(-8,86368+5,0157 \ln (\mathrm{D})-0,356478 \ln (\mathrm{H})) \mathrm{R}^{2}=0,89$

Biomassa das Folhas $=\operatorname{EXP}(-4,97247+2,21557 \ln (\mathrm{DAP})) \mathrm{R}^{2}=0,79$

Este resultado é bastante compreensivo do ponto de vista biológico, devido os vários fatores, tanto genético como do ambiente, que podem interferir na formação e no crescimento dos ramos e folhas.

Herbert \& Robertson (1991), testando regressões lineares correlacionando DAP x altura para 10 espécies de Eucalyptus com a idade de 7 anos, observaram correlações significativas para todos os componentes da biomassa, porém com valor menor para o componente folhas. Waterloo (1994), utilizando a mesma metodologia de correlação, para Pinus, também encontrou uma menor eficiência de correlação para as folhas do que para os demais componentes. 
4.4.3. Conteúdo de nutrientes na fitomassa arbórea.

Tabela 11. Fitomassa arbórea e nutrientes estocados $\left(\mathrm{kg} \cdot \mathrm{ha}^{-1}\right)$ nos diferentes componentes de Eucalyptus saligna e suas respectivas porcentagens do peso total.

\begin{tabular}{|c|c|c|c|c|c|c|c|}
\hline \multirow[t]{2}{*}{ Comp. } & \multirow{2}{*}{ 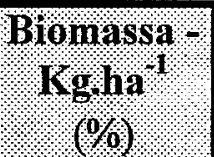 } & \multicolumn{6}{|c|}{$\begin{array}{l}\text { Fiementos - Kgha' } \\
(\%)\end{array}$} \\
\hline & & N/ & P. & T/. & Ca. & $\mathrm{Mg}$ & $\mathrm{S}$ \\
\hline LENHO & $\begin{array}{c}145180,48 \\
(81,5)\end{array}$ & $\begin{array}{c}102 \\
(50,63)\end{array}$ & $\begin{array}{c}29 \\
(55,04)\end{array}$ & $\begin{array}{c}160 \\
(51,8)\end{array}$ & $\begin{array}{c}145 \\
(18,24)\end{array}$ & $\begin{array}{c}44 \\
(32,71)\end{array}$ & $\begin{array}{c}15 \\
(47,5)\end{array}$ \\
\hline CASCA & $\begin{array}{c}14657,40 \\
(8,2)\end{array}$ & $\begin{array}{c}31 \\
(15,33)\end{array}$ & $\begin{array}{c}13 \\
(25,00)\end{array}$ & $\begin{array}{c}56 \\
(18,07)\end{array}$ & $\begin{array}{c}490 \\
(61,5)\end{array}$ & $\begin{array}{c}57 \\
(42,94)\end{array}$ & $\begin{array}{c}7 \\
(23,98)\end{array}$ \\
\hline$\overline{\text { RAMOS }}$ & $\begin{array}{c}13615,25 \\
(7,6)\end{array}$ & $\begin{array}{c}26 \\
(12,89)\end{array}$ & $\begin{array}{c}6 \\
(10,33)\end{array}$ & $\begin{array}{c}46 \\
(15,01)\end{array}$ & $\begin{array}{c}123 \\
(15,39)\end{array}$ & $\begin{array}{c}20 \\
(15,34)\end{array}$ & $\begin{array}{c}3 \\
(8,9)\end{array}$ \\
\hline$\overline{\text { FOLHAS }}$ & $\begin{array}{c}4616,18 \\
(2,6) \\
\end{array}$ & $\begin{array}{c}43 \\
(21,16) \\
\end{array}$ & $\begin{array}{c}5 \\
(9,63) \\
\end{array}$ & $\begin{array}{c}47 \\
(15,12) \\
\end{array}$ & $\begin{array}{c}39 \\
(4,87) \\
\end{array}$ & $\begin{array}{c}12 \\
(9,01)\end{array}$ & $\begin{array}{c}6 \\
(19,63) \\
\end{array}$ \\
\hline $\begin{array}{l}\text { Total } \\
(100 \%)\end{array}$ & 178069,31 & 200,75 & 52,76 & $\mathbf{3 0 8 , 3 1}$ & 796,06 & 133,13 & $\mathbf{3 0 , 5 7}$ \\
\hline & & \multicolumn{6}{|c|}{ Total exportado para fins comerciais } \\
\hline LENHO & 145180,48 & 101,63 & 29,04 & 159,70 & 145,18 & 43,55 & 14,52 \\
\hline$\overline{\text { CASCA }}$ & $\overline{14657,40}$ & 30,78 & 13,19 & 55,70 & 489,56 & 57,16 & 7,33 \\
\hline TRONCO & 159837,88 & 132,41 & 42,23 & 215,40 & 634,74 & 100,71 & 21,85 \\
\hline & & \multicolumn{6}{|c|}{ Total que permanece na área após a colheita } \\
\hline RAMOS & 13615,25 & 25,87 & 5,45 & 46,29 & 122,54 & 20,42 & 2,72 \\
\hline FOLHAS & 4616,18 & 42,47 & 5,08 & 46,62 & 38,78 & 12,00 & 6,00 \\
\hline
\end{tabular}

Schumacher (1993) verificou que o compartimento copa representa, para as três espécies estudadas (E. camadulensis, E. grandis e E. torelliana), cerca de $10 \%$ da fitomassa total e armazena em média $24 \%$ do total de nutrientes na árvore. Verificou, ainda, que no compartimento casca encontram-se as maiores quantidades do elemento cálcio, aproximadamente $60 \%$ do total.

As Figuras 15 e 16 apresentam o balanço geoquímico de nutrientes. 
A Figura 15 demonstra a contribuição anual da precipitação e saída via deflúvio (Kg.ha ${ }^{-1}$. ano $\left.{ }^{-1}\right)$ em relação ao teor de nutrientes contidos na árvore como um todo, os resíduos florestais (ramos+folhas) que ficam e o material removido da área (lenho+casca) $\left(\mathrm{Kg}_{\mathrm{h}} \mathrm{ha}^{-1}\right)$, após a colheita através do corte raso na microbacia $\mathrm{A}$.

A entrada via precipitação foi maior para todos os nutrientes nos períodos pré e pós-corte.

Após o corte, observa-se que houve um aumento para todos os estes nutrientes, principalmente $\mathrm{Ca}$, na água do deflúvio, em relação ao periodo anterior.

Os aumentos dos nutrientes na água do deflúvio estão relacionados com a lavagem dos nutrientes, através da chuva, dos resíduos florestais deixados na área, aliados aos sedimentos perdidos para o deflúvio (conforme mostrou a Figura 14), como também pela contribuição da chuva. Infelizmente, como foi justificado no ítem 4.2.2., a confirmação dessa possível contribuição da chuva, que seria obtida pela análise comparativa com o resultado da microbacia " $B$ ", que não sofreu o corte raso, ficou prejudicada.

As perdas estam relacionadas com o tamanho da área exposta e com o deflúvio, existindo indicações de que o corte raso, em solos pouco profundos e inférteis, propicia à depauperação pela perda de nutrientes, após à exposição do solo.

Por outro lado, as perdas de nutrientes através da exploração comercial (lenho+casca) representam $66,2 \% \mathrm{~N}, 81,1 \% \mathrm{P}, 69,9 \% \mathrm{~K}, 79,7 \% \mathrm{Ca}$ e $75,6 \%$ de $\mathrm{Mg}$. Estes valores significam que as saídas foram duas vezes maiores para $\mathrm{N}$ e $\mathrm{K}$, três para $\mathrm{Mg}$ e quatro para $\mathrm{P}$ e $\mathrm{Ca}$ do que a quantidade destes 
elementos deixados no campo (folhas+ramos), os quais representam: $34,2 \% \mathrm{~N}$, $19,9 \%$ P, 30,1\% K, 20,3\% Ca e 24,3\% de $\mathrm{Mg}$.

De acordo com Hornbeck et al. (1975), Whitehead \& Robinson (1993), Dahlgren \& Driscoll (1994) e Bruenig (1996), a operação silvicultural (corte raso) pode ocasionar um grande desequilíbrio nestes ecossistemas. Consequentemente, pode haver uma depauperação dos nutrientes do solo, ocasionando seu esgotamento e, por conseguinte, uma diminuição da produtividade florestal nas rotações sucessivas e necessidade de maiores níveis de adubação.

Assim, o manejo florestal empregado desempenha um importante papel na manutenção da produtividade da floresta, assim como na manutenção do crescimento florestal. 


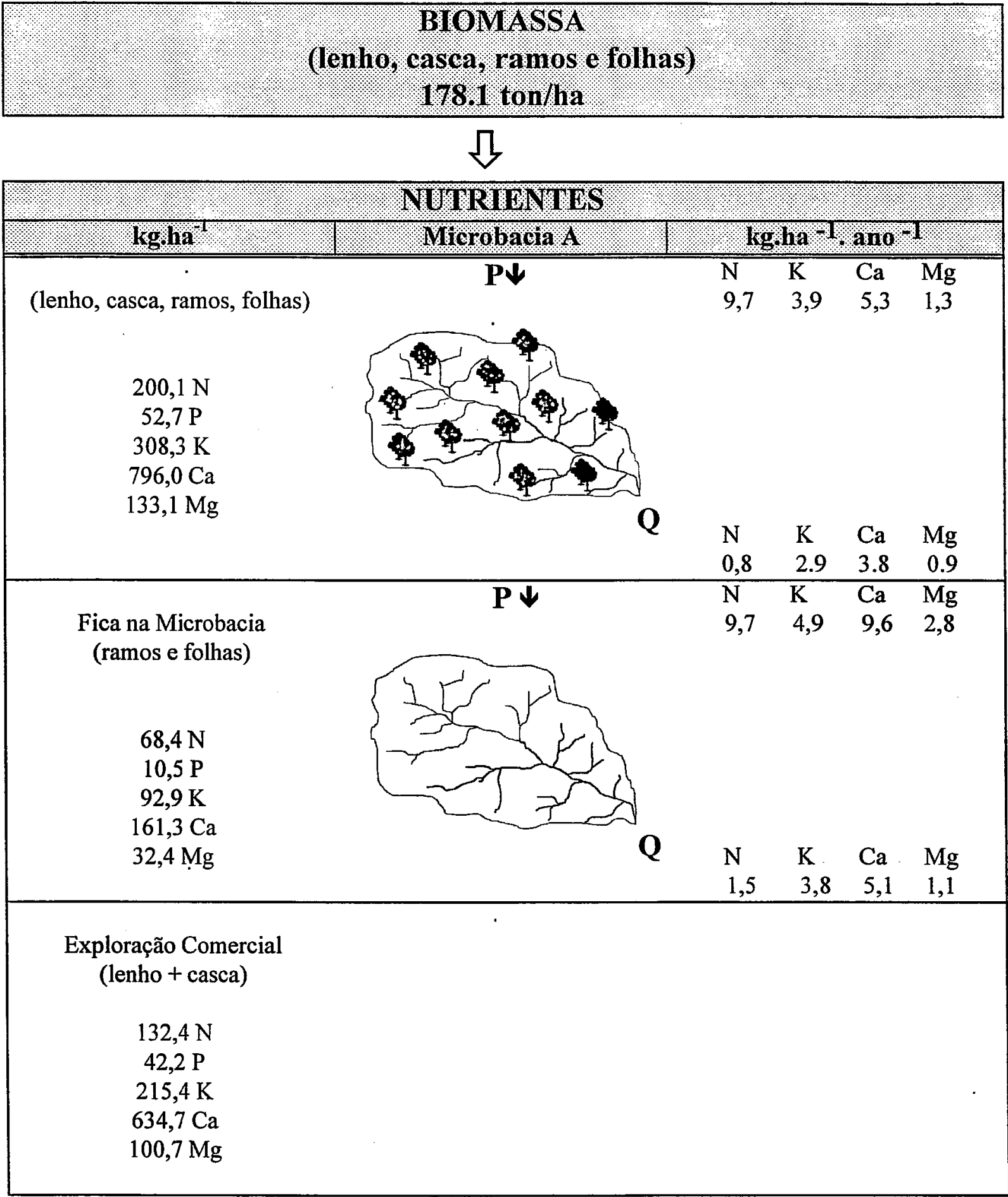

Figura 15. Balanço geoquímico de nutrientes $\left(\mathrm{kg} \cdot \mathrm{ha}^{-1} \cdot\right.$ ano $\left.^{-1}\right)$, sendo $(\mathrm{P})$ entrada via da chuva, (Q) saída via deflúvio na Microbacia A e biomassa (kg.ha $\left.{ }^{-1}\right)$ do lenho, casca, ramos e folhas (período: junho de 1987 a maio de 1995). 
A Figura 16 apresenta os valores totais para o balanço de nutrientes $\left(\mathrm{Kg} \mathrm{ha}^{-1}\right)$ para todo o período experimental na microbacia $\mathrm{A}$, onde é possível visualizar a condição da manutenção da produtividade do sítio após a exploração florestal.

A contribuição relativa da precipitação e adubação, em relação ao teor de nutrientes contidos no lenho+casca, mostrou que a entrada de nutrientes não foi significativa para todos os nutrientes, ficando abaixo do requerido, considerando-se à exploração do lenho+casca. Com a exploração somente do lenho, o balanço melhora, mais ainda continua negativo.

Stevens et al. (1995), calculando o estoque de nutrientes para um período completo de rotação, indicam que o $\mathrm{P}$ e Ca exportados na biomassa resultarão na exaustão destes elementos ao longo das rotações, e que os efeitos serão significativamente mais severos se a colheita total da árvore for praticada.

A casca é um componente da biomassa rico em nutrientes, principalmente o Ca. Observa-se que a permanência também da casca na área explorada, como resíduo florestal, contribui grandemente para diminuir a perda deste nutriente, que ficará disponível para a ciclagem geoquímica na bacia e rotações sucessivas. No entanto, a adubação é fator imprescindível para a manutenção da produtividade, visto que, mesmo contando com o estoque de nutriente trocáveis do solo (200 $\mathrm{cm}$ de profundidade), a produtividade será assegurada para rotações futuras apenas em 3,2 rotações para $\mathrm{K}, 1,8$ rotações para $\mathrm{Ca}$ e 8,3 rotações para $\mathrm{Mg}$, no caso da colheita presentemente adotada (lenho+casca). Estes valores sobem para 4,5 rotações para $\mathrm{K}, 9,9$ rotações para $\mathrm{Ca}$ e 18,9 rotações para $\mathrm{Mg}$, considerando-se apenas a colheita do lenho. 


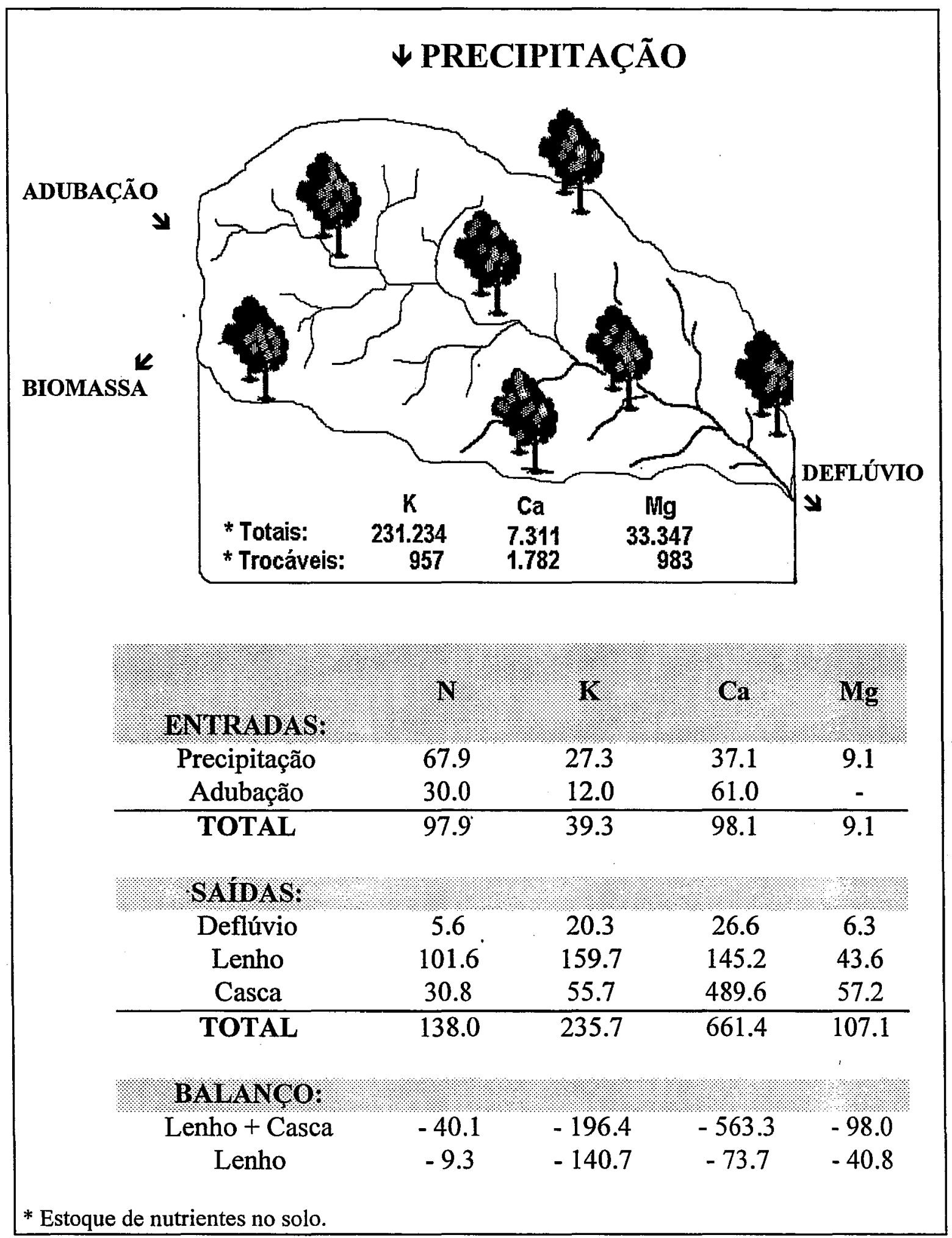

Figura 16. Valores totais para o balanço de nutrientes (manutenção da produtividade) em kg.ha ${ }^{-1}$ na Microbacia A (Período: junho de 1987 a maio de 1995). 
Bruijnzeel (1990), em uma revisão sobre a hidrologia das florestas tropicais e o efeito da conversão, verificou que o $\mathrm{P}$ mostrou ser acumulativo em quase todos os estudos verificados para solos de níveis de fertilidade diferentes, refletindo muito baixa mobilidade deste elemento.

No presente estudo, mais crítico ainda é a situação do Ca, que se encontra estocado em elevada porcentagem na biomassa das árvores, principalmente na casca, a qual representa $61,5 \%$ do estoque de nutrientes estocados na biomassa das árvores acima do solo.

Levando-se em conta a situação do lenho+casca retirados do sítio, esta representa uma perda de $79,74 \%$ deste nutrientes.

Os outros nutrientes minerais também encontram-se estocados em elevadas porcentagens na biomassa das árvores acima do solo; esta é uma forte indicação da não conveniência de rotações curtas e a exploração dos resíduos florestais (folhas, ramos, e casca), principalmente a casca, evitando perdas comprometedoras para o $\mathrm{Ca}$, seguido do $\mathrm{K} \mathrm{e} \mathrm{Mg}$, a não ser que esta saída de nutrientes devido a exploração da floresta seja reposta através das adições naturais ou artificiais, para evitar o empobrecimento do sítio através de rotações sucessivas.

Matéria orgânica deixadas no solo pode indicar nutriente disponível durante sucessão ou estabelecimento de plantações.

Medidas práticas recomendadas, além da adubação química rotineira aplicada por ocasião do plantio e/ou condução da rebrota, incluem a adubação com resíduos da própria indústria, que poderá ser utilizada como reforço para a adubação química, como também o uso das cinzas, as quais são ricas em $\mathrm{Ca}, \mathrm{K}$, e $\mathrm{Mg}$. 
Enfim, para manter a produtividade do sítio, o aumento do período de rotação da floresta, para otimizar o ciclo de nutrientes, a forma de preparo do solo e de extração da madeira, seriam outras práticas recomendáveis.

Os resultados devem ser analizados de forma crítica face às implicações ecológicas e silviculturais, tendo em vista o baixo estoque de nutrientes disponíveis no solo. 


\section{CONCLUSÕES}

a) O balanço hídrico para as duas microbacias (A e B) mostrou-se dentro dos valores esperados, tanto para o período pré, quanto para o pós tratamento. Conforme tem sido verificado em numerosos outros trabalhos similares, foi observada uma diminuição do deflúvio, proporcionalmente ao crescimento da vegetação, e um aumento após o corte raso da floresta, dentro da variação que tem sido observada para outras espécies florestais.

b) O impacto causado pela colheita florestal resultou numa alteração da qualidade da água, principalmente para sedimentos em suspensão, representando assim um aumento das perdas de solo da área após o corte.

c) Durante o período pré-corte, as perdas de nutrientes através do deflúvio foram ligeiramente maiores para a microbacia B. Após a colheita, houve um aumento, dentro do esperado, para a maior parte dos nutrientes estudados na microbacia A. Por outro lado, o balanço geoquímico de nutrientes, o qual relaciona estas perdas com as entradas via precipitação, demonstrou ser positivo para a maior parte dos nutrientes, em ambas as microbacias.

d) As perdas de solo via sedimentos em suspensão no deflúvio, apesar de apresentar um valor duas vezes maior após a colheita na microbacia A, foram sempre menores do que as perdas verificadas em trabalhos similares. 
e) As perdas de nutrientes pela exportação da biomassa lenhosa mostrou ser o efeito mais impactante após o corte raso, principalmente para o $\mathrm{Ca}$, seguido do $\mathrm{K}$ e $\mathrm{Mg}$. 


\section{RECOMENDAÇÕES}

- Em face dos valiosos dados obtidos no decorrer destes oito anos experimentais, através deste trabalho, recomenda-se prosseguimento do monitoramento da água do deflúvio nas microbacias A e B, bem como a determinação dos parâmetros físico e químicos tanto da água da chuva como na água do deflúvio de ambas microbacias.

- Devido a fase de crescimento da rebrota na microbacia $\mathrm{A}$, com o próximo estudo poderá ser conduzido no sentido de verificar o tempo nacessário para a estabilização do deflúvio, da qualidade da água e sedimento em suspensão aos níveis.pré-tratamento da microbacia.

- Recomenda-se o estudo do impacto causado pela exploração florestal em faixas ou em parcelas progressivas, os quais poderão ser comparados com os resultados obtidos no presente estudo. Estas alternativas de manejo têm-se mostrado menos impactante quanto as perdas de nutrientes e sedimentos das áreas exploradas.

- A microbacia B poderá ser mantida como testemunha para estudos futuros, visto que, a exemplo do que pode ser constatado na microbacia $\mathrm{A}$, o corte raso na microbacia $\mathrm{B}$ provocaría resultados mais críticos quanto à perda de sedimento, liberação de nutrientes via deflúvio (devido sua maior 
declividade e característica do solo) e, possivelmente, maior comprometimento para rotações futuras, devido ao estoque de nutrientes trocáveis no solo desta microbacia apresentarem valores ainda menores aos encontrados na microbacia $\mathrm{A}$.

- Quanto à manutenção da capacidade de suporte para explorações sucessivas, esta envolve, além das alternativas de manejo, a preocupação quanto à reposição e complementação de nutrientes para a área de estudo, tendo em vista a baixa capacidade de nutrientes estocados no solo, e a quantidade de nutrientes retirados com o lenho e principalmente com a casca.

- É muito importante testar alternativas de manejo para que os impactos sejam menores nas rotações sucessivas, envolvendo, por exemplo, práticas tais como: época do corte, manutenção das estradas e aceiros, uso mínimo possível de máquinas pesadas para evitar a compactação do solo e, consequentemente, o aumento do escoamento superficial, o qual propicia o arraste de partículas e nutrientes do solos. 


\section{REFERÊNCIAS BIBLIOGRÁFICAS}

AMERICAN PUBLIC HEALTH ASSOCIATION. Standard methods for the examination of water and Wastewater. Boston: APHA, AWA, WPCP, 1976. 1193 p.

ANDRAE, F.H. Ecologia florestal. Santa Maria: Universidade Federal de Santa Maria, 1978. 230p.

ANDRAE, F.H.; KRAPFENBAUER, A. Pesquisas Austro-Brasileiras 19731982 sobre Araucaria angustifolia, Podocarpus lambertii e Eucalyptus saligna. Wien: Universität für Bodenkulter, 1983. 112p.

ARCOVA, F.C.S.; CICCO, V. Fluxo' de nutrientes através da precipitação, precipitação interna e escoamento pelo tronco em floresta natural secundária no Parque Estadual da Serra do Mar-Núcleo Cunha - SP. Boletim Técnico do Instituto Florestal de São Paulo, v. 41, n.1, p. 37-58, 1987.

ARCOVA, F.C.S.; CICCO, V.; LIMA, W.P. Balanço dos nutrientes Ca+2, $\mathrm{Mg}+2, \mathrm{Na}+1, \mathrm{~K}+1$ e NO3-1 em bacia hidrográfica experimental com vegetação natural no Parque Estadual da Serra do Mar - Núcleo Cunha, SP. IPEF, n. 31 p.61-67, dez. 1985.

ATTIWILL, P.M; GUTHRIE, H.B; LEUNING, R. Nutrient cycling in a Eucalyptus obliqua forest: 1 litter production and nutrient return. Australian Journal of Botany, v. 26, p. 79-91, 1978.

BARGALI, S.S.; SINGH, S.P. Aspects of produtivity and nutrient cycling in an 8-yer-old Eucalyptus plantation in a moist plain area adjacent to Central Himalaya, India. Canadian Journal of Forestry Research, v. 21, n. 21, p. 1365-1372, 1991. 
BATALHA, BEN-HUR L.; PARLATORE, A.C. Controle da qualidade da água para consumo humano: bases conceituais e operacionais. São Paulo: CETESB, 1977. 198p.

BORMANN, F.H.; LIKENS, G.E. Nutrient cycling. Science, v. 155, p. 424-429, 1967.

BOS, M.G. Discharge measurement structures. Wageningen: ILRI, 1976. $464 \mathrm{p}$.

BRASIL. Ministério da Agricultura. Secretaria Nacional de Planejamento Agrícola. Aptidão agrícola das terras de São Paulo. Brasília: BINAGRI, 1979. v. 20, 11p.

BRASIL. Ministério das Minas e Energia. Projeto RADAM BRASIL. Folha SF. 23/24 Rio de Janeiro/Vitória. Rio de Janeiro, 1983. (Levantamento de Recursos Naturais, 32).

BRAY, J.R.; GORHAM, E. Litter production in forests of the world. Advances in Ecological Research, v. 2, p. 101 - 157, 1964.

BROOKS, K.N.; FFOLLIOTT, P.F.; GREGERSEN, H.M. et al. Hydrology and the management of watersheds. Ames: Iowa State University Press, 1991. $391 \mathrm{p}$.

BROWN, E.M.W.; SKOUGSTAD, M.W.; FISHMAN, M.J. Methods for collection and analysis of water samples for dissolved minerals and gases. Washington: United States Geological Survey, 1970. 160 p. (Laboratory Analysis, 5).

BRUENIG, E.F. Conservation and management of tropical rainforests: an integrated approach to sustainability. Cambridge: University Cambridge; CAB International, 1996. 339p.

BRUIJNZEEL, L.A. Environmental impacts of deforestation in the humid tropics: a watershed perspective. Wallaceana, v. 46, p. 3-12, 1986.

BRUIJNZEEL, L.A. Hydrology of moist tropical forest and effects of convertion: a state of knowledge review. Amsterdam: UNESCO, 1990. 224p.

BRUIJNZEEL, L.A. Nutrient input-output budgets of tropical forest ecosystems: a review. Journal of Tropical Ecology, v. 7, n. 1, p. 1-24, 1991. 
COUTINHO, L.M. Aspectos ecológicos do fogo no cerrado. III. A precipitação atmosférica de nutrientes minerais. Revista Brasileira de Botânica, v. 2, n.2, p. 97-101, dez. 1979.

COUTO, H.T.Z.; BASTOS, N.L.M. Modelos de equações de volume e relações hypsométricas para plantações de Eucalyptus no Estado de São Paulo. IPEF, v. 47, p. 33-44, 1987.

CUEVAS, E.; MEDINA, E. Nutrient cycling in the conservation of soil fertility in the tropics. In: CONGRESSO LATINO AMERICANO DE CIÊNCIA DO SOLO, Águas de Lindóia, 1996. São Paulo: SONOPRESS, 1996. Compact disc.

DAHLGRER, R.A.; DRISCOLL, C,T. The effects of Whole-tree clear-cuting on soil processes at the Hubbard Brook Experimental Forest. USA. Plant and Soil, v. 158, p. 239-262, 1994.

DEPARTAMENTO DE ÁGUA E ENERGIA ELÉTRICA. Caracterização dos recursos Hídricos do Estado de São Paulo. São Paulo, 1970. 10 p.

DYE, P.J.; POULTER, A.G. A field demonstration of the effect on streamflow of clearing invasive and wattle trees from a riparian zone. South African Forestry Journal, v. 173, p. 27-30, 1995.

FAHEY, B. The effect of plantation forestry on water yeld in New Zealand. New Zealand Forestry, v.39, n. 3, p. 18-23, 1994.

FELLER, M.C.; KIMMINS, J.P. Effects of clearcutting and slash burning on streamwater chemistry and watershed nutrient budgets in southwestern British Columbia. Water Resources Research, v. 20, n. 1, p. 29-40, 1984.

FLINN, D.W.; BREN, L.J. ; HOPMANS, P. Soluble nutrient inputs from rain and outputs in stream water from small forested catchment. Autralian Forestry, v. 42, n. 1, p. 39-49, 1979.

GIOLITO, I. Métodos espectrofotométricos de análise química. São Paulo: Grupo de Coordenação Para o Aperfeiçoamento Técnico, 1968. 151p.

GOLLEY, F.B.; McGINNIS, J.T.; CLEMENTS, R.G. et al. Ciclagem de minerais em um ecossistema de floresta tropical úmida. São Paulo: EPU; EDUSP, 1978. 256p. 
GOMES, F.P.; GARCIA, C.H. A interpretação econômica de adubação de Eucalyptus grandis. IPEF, n. 43/44, p. 1-83, 1990.

GUERRINI, I.A. Uso de resíduos industriais em florestas. In: CONGRESSO LATINO AMERICANO DE CIÊNCIA DO SOLO, Águas de Lindóia, 1996. São Paulo: SONOPRESS, 1996. Compact disc.

GUTHRIE, H.B.; ATTIWILL, P.M. ; LEUNING, R. Nutrient cycling in a Eucalyptus obliqua (L'Herit.) Forest [In Victoria]. II. A study in small catchment. Australian Journal of Botany, v. 26, n. 2, p. 189-201, Apr. 1978.

HANSEN, E.A.; BAKER, J.B. Biomass and nutrient removal in short rotation intensively cultured plantations. In: IMPACT HARVESTING ON FOREST NUTRIENT CYCLING, 1979. Proceedings. p. 130-151. /Resumo em TREECD on CD-ROM, 1939-1996/.

HARRISON, R.B. Use of urban residues in forests. In: CONGRESSO LATINO AMERICANO DE CIÊNCIA DO SOLO, Águas de Lindóia, 1996. São Paulo: SONOPRESS, 1996. Compact disc.

HAVEREN, B.P. Reevaluation of the wagon wheel gap forest watershed experiment. USA Colorado. Forest Science, v. 34, n. 1, p. 208-214, 1988.

HERBERT, M.A.; ROBERTSON, M.A. Above-ground biomass composition and nutrient content for eucaliptus species in the southeastern Transvaal. In:. IUFRO SYMPOSIUM INTENSIVE FORESTRY: THE ROLE OF EUCALYPTUS, Durban, 1991. Proceedings. Durban: IUFRO, 1991. v. 2, p. 662-674.

HEWLETT, J.D. Principles of forest hydrology. Athens: the University of Georgia Press, 1982. 183p.

HOPMANS, P.; FLINN, D.W.; FARRELL, P.W. Nutrient dynamics of forested catchments in southeastern Australia and changes in water quality and nutrient exports following clearing. Forest Ecology and Management, v. 20, n. 34, p. 209-231, 1987.

HORNBECK, J.W.; KROPELIN, W. Nutrient removal and leaching from a whole-tree harvest of northerm hardwoods. Journal of Environmental Quality, v. 11, n.2, p. 309-316, 1982. 
HORNBECK, J.W.; URSIC, S.J. Intensive harvest and forest streams: are they compatible? In: IMPACT OF INTENSIVE HARVESTING ON FOREST NUTRIENT CYCLING, 1979. Proceedings. p. 249-262. /Resumo em TREECD on CD-ROM, 1939 - 96/.

HORNBECK, J.W.; PIERCE, R.S.; LIKENS, G.E. et al. Moderating the impact of contemporany forest cutting on hydrological and nutrient cycles. U.S.A. New Hampshire IAHS-Publication, v. 117, p. 423-429, 1975.

HOYT, W.G.; TROXELL, H.C. Forest and streamflow. Transactions of the American Society of Civil Engineers, v. 56, p. 1-32, 1932.

JOHNSON, E.A.; DILS, R.E. Outline for compiling precipitation, runoff, and ground water data from small watersheds. Ashville: USDA Forest Service Stations, 1956. 41p. (Paper, 68).

JORDAN, C.F. The nutrient balance of amazonian rain forest. Ecology, v. 63, n. 3, p. 647-654, 1982.

JORDAN, C.F.; RUSSELL, C.E. JARI: Productivity of plantations and burn. Interciência, v.8, n. 5, p. 294-297, 1983.

JORGENSEN;'J.R.; WELLS, C.G. Tree nutririon and fast-growing plantation in developing countries. International Tree-Crops Journal, v.3, n. 4, p. 225244, 1986.

LEOPOLDO, P.R.; FRANKEN, W.; MATSUI, E. et al. Estimativa da evapotranspiração da floresta Amazônica de terra firme. Acta Amazônica, v. 12, supl. 3, p. 23-28, set. 1982.

LIKENS, G.E.; BORMANN, F.H.; JOHNSON, N.M. et al. The calcium, magnesium, potassium, and sodium budgets for a small forested ecosystem, Ecology, v. 48, n.5, p. 772-785, 1967.

LIKENS, G.E.; BORMANN, F.H.; PIERCE, R.S. et al. Biogeochemistry of a forested ecosystem. New York: Springer-Verlag, 1977. 146p.

LIMA, W.P. Princípios de hidrologia florestal para o manejo de bacias hidrográficas. Piracicaba: ESALQ, 1986. 242p.

LIMA, W.P. Impacto ambiental do eucalipto. São Paulo: EDUSP, 1993. 301p. 
LIMA, W.P. Impactos da cultura do Eucalipto. Silvicultura, v. 16, n. 64: 32-38, 1995.

LIMA, W.P.; POGGIANI, F. ; VITAL, A.R. Impactos ambientais de Plantações florestais sobre regime hídrico e de nutrientes em bacias hidrográficas. In: CONGRESSO LATINO AMERICANO DE CIÊNCIA DO SOLO, Águas de Lindóia, 1996. São Paulo: SONOPRESS, 1996. Compact disc.

LOWRANCE, R.R.; TODD, R.L.; ASMUSSEN, L.E. Nutrient cycling in an agricultural watershed: I. Phreatic movement. Journal of Environmental Quality, v. 13, n. 1, p. 22-27, 1984.

MALMER, A.; GRIP, H. Converting tropical rainforest to forest plantation in Sabah, Malaysia. Part II. Effects on nutrient dynamics and net losses in streamwater. Hydrological Processes, v. 8, n. 3, p. 195-209, 1994.

MARISON, G.M. Biomass and nutrient removal in long-rotations stands. In: IMPACT OF INTENSIVE HARVESTING ON FOREST NUTRIENT CYCLING, 1979. Proceedings. p. 98 - 110. /Resumo em TREECD on CDROM, 1939 - 96/.

McCULLOCH, J.S.; ROBINSON, M. History of forest hydrology. Journal of Hydrology, v, 150, n. 2/4, p. 189-216, 1993.

MONTGOMERY, D.R.; GRANT, G.E.; SULIVAN, K. Watershed analysis as a framework for implementing ecosystem management. Water Resources Bulletin, v. 31, n. 3, p 369-386, June 1995.

MORO, L. Utilização da "cinza"de biomassa florestal como fonte de nutrientes em povoamentos puros de Eucalyptus grandis. Piracicaba, 1994. 53p. Dissertação (Mestrado) - Escola Superior de Agricultura "Luiz de Queiroz"; Universidade de São Paulo.

NAMBIAR, S. Intensive production of plantations and their sustainability in context. In: CONGRESSO LATINO AMERICANO DE CIENCIAS DO SOLO, Águas de Lindóia, 1996. São .Paulo: SONOPRESS, 1996. Compact disc.

NASCIMENTO, C.M.; PEREIRA, M.A.M.G. Atlas climatológico do Estado de São Paulo (1977-1978). Campinas: Fundação Cargill, 1988. 93p. 
NEARY, D.G; HORNBECK, J.W. Impacts of harvesting and associated practices on off-site environmental quality. In: Impacts of harvesting and associated practices on off-site environmental quality. Chapmann \& Hall, 1994. p. 1109.

O'LOUGHLIN, C. The forest and water relationship. New Zealand Forestry, v. 39, n. 3, p. 26-30, 1994.

PEREIRA, M.G.M. An analyses of the future productivity of Eucalyptus grandis plantations in the cerrado region in Brasil: a nutrient cycling approach Vancouver, 1984. 230p. Thesis (Ph.D) - University of British Columbia.

POGGIANI, F. Ciclagem e exportação de nutrientes em florestas para fins energéticos. In: SIMPÓSIO ENERGIA DA BIOMASSA FLORESTAL, São Paulo, 1983. São Paulo, CESP; Piracicaba, IPEF, 1983. p. 17-30.

POGGIANI, F. Ciclagem de nutrientes em ecossistemas de plantações florestais de Eucalyptus e Pinus. Implicações Silviculturais. Piracicaba, 1985. 210p. Tese (Livre-Docência) - Escola Superior de Agricultura "Luiz de Queiroz"; Universidade de São Paulo.

POGGIANI, F. Nutrient cycling Eucalyptus and Pinus plantation ecosystems, silvicultural implications. In. WORKSHOP ON BIOCHEMISTRY OF RAIN FORESTS: PROBLEMS FOR RESEARCH, Piracicaba, 1987. Proceedings. Piracicaba: CENA, 1987. p. 39-46.

POGGIANI, F.; REZENDE, G.C.; SUITER FILHO, W. Efeito do fogo na brotação e crescimento de Eucalyptus grandis após o corte raso e alterações nas propriedades do solo. IPEF, n. 24, p. 33 - 42, 1983.

POGGIANI. F.; COUTO, H.T.Z.; CORRADINI, L. et al. Exportação de biomassa e nutrientes através da explotação dos troncos e das copas de um povoamento de Eucalyptus saligna. IPEF, n. 25, p. 37-39, 1983.

POORE, M.E.D.; FRIES, C. The ecological effects of Eucalyptus. FAOForestry Paper, n. 59, p. 1-87, 1985.

PRITCHETT, W.L.; FISHER, R.F. Properties and management of forest soil. New York: John Willey, 1987. 500 p. 
RANGER, J.; BONEAU, M. Predictable effects of intensifying production and harvesting on the fertility of forest soil. Part 2 . The effects of silviculture. Revue Forestiere Francaise, v. 38, n. 2, p. 105-123, 1986.

RANZINI, M. Balanço hídrico, ciclagem geoquímica de nutrientes e perdas de solo em duas microbacias reflorestadas com Eucalyptus saligna Smith no Vale do Paraíba, SP. Piracicaba, 1990. 99p. Dissertação (Mestrado) - Escola Superior de Agricultura "Luiz de Queiroz", Universidade de São Paulo.

ROWE, L.K.; FAHEY, B.D. Hydrology and water chemistry changes after harvesting small, indigenous forest catchments, Westland, New Zealand. In: Proceedings of the Vienna Symposium. 1991. International Association of Hydrological Sciences, n. 203, p. 259-266, 1991.

ROWE, L.K.; PEARCE, A.J. Hydrology and related changes after harvesting native forest catchments and establishing Pinus radiata plantations. Part 2.The native forest water balance and changes in streamflow after harvesting. Hydrological Processes, v. 8, n. 4, p. 281-297, 1994.

SÃO PAULO. Secretaria dos Serviços e Obras Públicas. Departamento de Água e Energia Elétrica. Atlas pluviométrico do Estado de São Paulo (Período 1941-1970). São Paulo, 1972. 84p.

SARRUGE, J.R.; HAAG, H.P. Análise química em plantas. Piracicaba: ESALQ, 1974. 56p.

SCARDUA, F.P. Caracterização hidrológica de uma microbacia hidrográfica da estação experimental de Ciências Florestais de Itatinga. Piracicaba, 1994. 94p. Dissertação (Mestrado) - Escola Superior de Agricultura "Luiz de Queiroz", Universidade de São Paulo.

SCHUMACHER, M.V. Aspectos da ciclagem de nutrientes e do microclima em talhões de Eucalyptus camadulensis Dehnh, Eucalyptus grandis Hill ex Maiden e Eucalyptus torelliana F.Muell. Piracicaba, 1992. 87p. Dissertação (Mestrado) - Escola Superior de Agricultura "Luiz de Queiroz", Universidade de São Paulo.

SCHUMACHER, M.V.; POGGIANI, F. Produção de biomassa e remoção de nutrientes em povoamentos de Eucalyptus camaldulensis Dehnh, Eucalyptus grandis Hill ex Maiden e Eucalyptus torelliana F. Muell, plantados em Anhembi-SP. Ciência Florestal, Santa Maria, 3 (1): 21 - 34, 1993. 
SMITH, R.E. Effect of clearfelling pines on water yeld in small eastern Transvaal catchment, South Africa. Water, v. 17, n.3, p. 217-224, 1991.

STEVENS, P.A.; NORRIS, A.D.; WILLIAMS, T.G. Nutrient losses after clearfelling in Bedgelert Forest: a comparison of the effects of conventional and Whole-tree harvest on soil water chemistry. Forestry, v. 68, n.2, p. 115$131,1995$.

STEWART, H.T.L.; HOPMANS, P.; FLINN, D.W. Harvesting effects on phosphorus availability in a mixed eucalypt ecosystem in southeastern Australian Forest Ecology and Management, v.36, p. 149-162, 1990.

TALSMA, T.; HALLAM, P.M. Stream water quality of forested catchment in Cotter Walley, Act. IN: Proceedings NATIONAL SYMPOSIUM ON FOREST HYDROLOGY, 1., Melbourne, 1982. Australia, The Institution of Engineers, 1982, p. 29-50.

TAMM, C.O. Towards and understanding of the relations between tree nutrition, nutrient cycling and environmental. Plant and Soil, v. 168/169, p. 21-27, 1995.

TAPPI. TAPPI test methods - 1994/95. Atlanta, 1995. 1v.

VENTURA, A; BERENGUT, G; VICTOR, M.A.M. Características edafoclimáticas das dependências do Serviço Florestal do Estado de São Paulo. Silvicultura em São Paulo, v. 4/5, n. 4, p. 57-140, 1965/66.

WATERLOO, M.J. Water and nutrient dynamics of Pinus caribaea plantation forest on former grasland soil in Southwest Viti Levy, Fiji. Amsterdam, 1994. 478p. Thesis - Vrije Universiteit Amsterdam.

WHITE, E.H.; HARVEY, A.E. Modification of intensive management practices to protect forest nutrient cycles. In: IMPACT OF INTENSIVE HARVESTING ON FOREST NUTRIENT CYCLING, 1979. Proceedings. p. 264-279. /Resumo em TREECD on CD-ROM, 1939 - 96/.

WHITE, R.E. Introducion to the principles and practice of soil science. 2. ed. Oxford: BlackWell Scientific Publications, 1987.243p.

WHITEHEAD, P.G.; ROBINSON, M. Experimental basin studies-an international and historical perspective of forest impacts. Amsterdam Journal of Hydrology, v 145, p. 217-230, 1993. 
APÊNDICE 1 - Análise de solo da microbacia A.

Classificação: PODZÓLICO VERMELHO-AMARELO álico Tb moderado textura média/argilosa.

Unidade de Mapeamento: Mcccvfd (montanhoso convexo/convexo côncavo fortemente dissecado).

Altitude: $\quad 700$ metros.

Material de Origem: Serecita/xisto com cobertura colúvio/aluvionar Pleistocênica.

Relevo Regional: Ondulado forte.

Relevo Local: Cabeceira de drenagem parte alta.

Erosão: $\quad$ Laminar forte.

Drenagem: Boa.

Descrição morfológica:

Ap 0-22 cm: pardo avermelhado (5YR 4/3 úmido); barro argiloso; moderada média granular e blocos subangulares; muito friável, ligeiramente plástico e pegajoso; transição ondulada e clara.

$\mathrm{Bt}$

22-64 cm: vermelho amarelado (5YR 4/8 úmido); barro argiloso; moderada média e grande prismática; friável, muito plástico e muito pegajoso; cerosidade moderada abundante; transição irregular e difusa.

64-106 cm: vermelho amarelado (5YR 5/8 úmido); barro argila; fraca média prismática; friável, muito plástico e 
muito pegajoso; cerosidade descontínua e pouca; transição ondulada e difusa.

BC 106-200+cm: vermelho (2,5 YR úmido); argila; fraca média e grandes blocos subangulares; friável, ligeiramente plástico e pegajoso; esqueleto de quartzo até $2 \mathrm{~cm}$ pouco.

Observações: Raízes finas abundantes no Ap, poucas no Bt1.

Muito finas comuns no $2 \mathrm{Bt} 2$ e poucas no $\mathrm{BC}$.

Macroporos abundantes.

Linha de seixos de quartzo, por volta de $10 \mathrm{~cm}$ de espessura, na base do Bt1. 


\begin{tabular}{|c|c|c|c|c|c|}
\hline \multirow{2}{*}{ HOR. } & SIMB. & $\mathbf{A}$ & Bt1 & Bt2 & BC \\
\hline & PROF.(cm) & $0-22$ & $22-64$ & $64-106$ & $106-200$ \\
\hline \multirow{3}{*}{$\begin{array}{l}\text { COM } \\
\text { POSI } \\
\text { ÇÃO }\end{array}$} & $\%$ AREIA & 16,0 & 15,1 & 12,0 & 10 \\
\hline & GROSSA & & & & \\
\hline & $\%$ AREIA & 33,0 & 28,0 & 28,2 & 26 \\
\hline \multirow{4}{*}{$\begin{array}{c}\text { ORGA } \\
\text { NULO } \\
\text { MÉTRI } \\
\text { CA }\end{array}$} & FINA & & & & \\
\hline & $\%$ SILTE & 20,1 & 17,5 & 11,3 & 7,6 \\
\hline & $\%$ ARGILA & 30,9 & 39,4 & 48,5 & 56,4 \\
\hline & $\begin{array}{c}\% \text { ARGILA } \\
\left(\mathrm{H}_{2} \mathrm{O}\right)\end{array}$ & 18,1 & 25,1 & $\overline{2,2}$ & 1,8 \\
\hline \multicolumn{2}{|c|}{ GRAU DE FLOCULAÇÂO \% } & 41,4 & 36,2 & 95,5 & 96,8 \\
\hline \multirow{3}{*}{$\mathrm{g} / \mathrm{cm}^{3}$} & DENSIDADE & 1,2 & 1,2 & 1,3 & 1,2 \\
\hline & APARENTE & & & & \\
\hline & DENSIDADE REAL & $\overline{2,3}$ & 2,6 & 2,5 & 2,7 \\
\hline \multirow{2}{*}{$\begin{array}{c}\mathrm{pH} \\
1: 2,5\end{array}$} & $\left(\mathrm{H}_{2} \mathrm{O}\right)$ & 4,6 & 4,6 & 4,5 & 4,7 \\
\hline & $\mathrm{KCl}$ & 3,9 & 4,0 & 4,0 & 4,3 \\
\hline \multicolumn{2}{|c|}{ C. ORGÂNICO \% } & 1,94 & 1,24 & 1,08 & 1,03 \\
\hline \multicolumn{2}{|r|}{$\mathrm{P}_{\mathrm{ppm}}$} & 6,1 & 2,0 & 0,8 & 0,8 \\
\hline \multirow{3}{*}{$\begin{array}{c}\text { COM } \\
\text { PLEXO }\end{array}$} & $\mathrm{Ca}^{+}$ & 1,64 & 0,35 & 0,22 & 0,14 \\
\hline & $\mathrm{Mg}^{+F}$ & 1,48 & 0,42 & 0,15 & 0,12 \\
\hline & $\mathrm{K}^{+}$ & 0,38 & 0,10 & 0,07 & 0,05 \\
\hline \multirow{2}{*}{$\begin{array}{c}\text { SOR } \\
\text { TIVO }\end{array}$} & $\mathrm{Na}^{+}$ & 0,05 & 0,06 & 0,02 & 0,06 \\
\hline & $\mathrm{S}$ & 3,55 & 0,93 & 0,46 & 0,37 \\
\hline \multirow{3}{*}{$\begin{array}{l}\mathrm{mE} / \\
100 \mathrm{~g}\end{array}$} & $\mathrm{Al}^{7}$ & 0,94 & 1,45 & 1,40 & 0,33 \\
\hline & $\mathrm{H}^{+}+\mathrm{Al}^{3+}$ & 5,22 & 4,70 & 3,81 & 2,50 \\
\hline & $\mathrm{T}$ & 8,77 & 5,63 & 4,27 & 2,87 \\
\hline \multicolumn{2}{|c|}{ SAT. BASES V\% } & 40 & 17 & 11 & 13 \\
\hline \multicolumn{2}{|r|}{ SAT. $\mathrm{Al}^{7+\%}$} & 21 & 61 & 75 & 47 \\
\hline \multicolumn{2}{|r|}{ POROSIDADE } & 48 & 54 & 48 & 56 \\
\hline
\end{tabular}




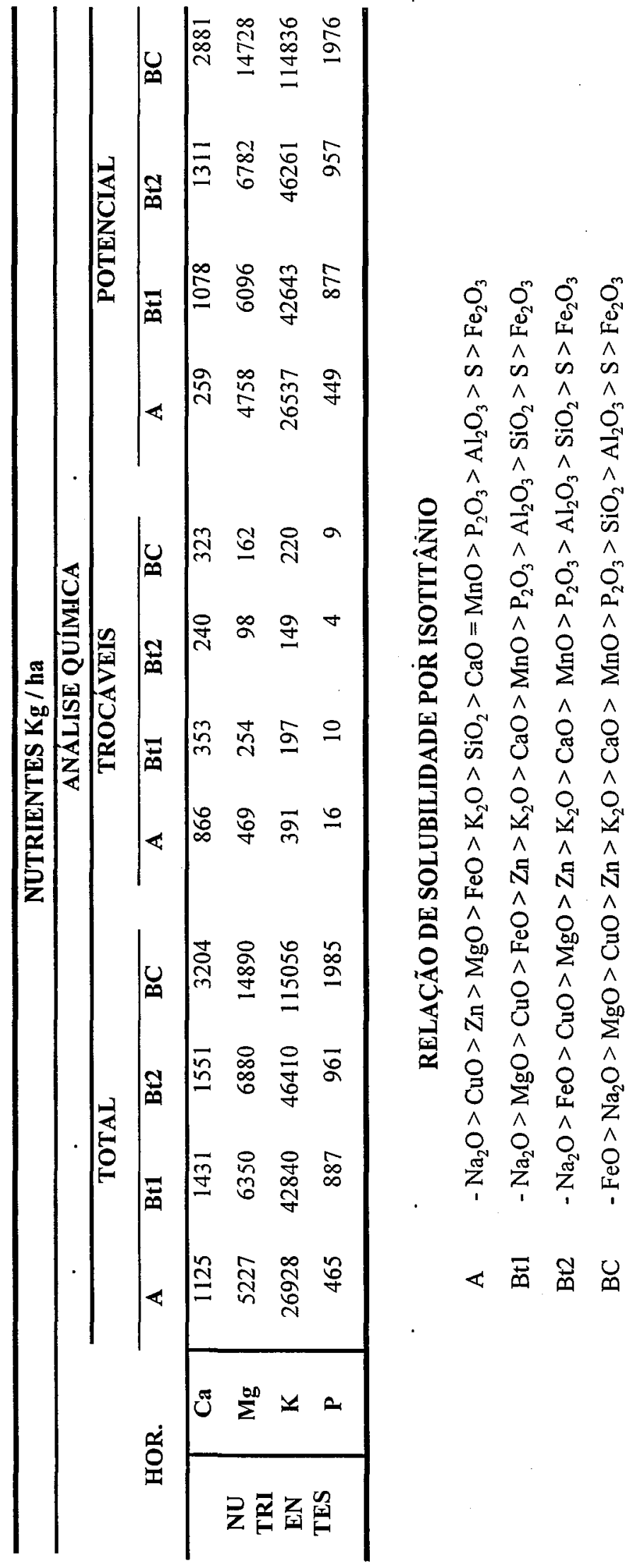


APÊNDICE 2 - Análise de solo da microbacia B.

Classificação: PODZÓLICO VERMELHO-AMARELO álico Tb moderado textura média/argilosa.

Unidade de Mapeamento: Mcccvfd (montanhoso convexo/convexo côncavo fortemente dissecado).

Altitude: $\quad 700$ metros.

Material de Origem: Serecita/xisto com cobertura colúvio/aluvionar Pleistocênica (cobertura ausente no terço inferior da microbacia).

Relevo Regional: Ondulado forte.

Relevo Local: Terço superior da encosta - encosta NE..

Erosão: Laminar.

Drenagem: Boa.

Descrição morfológica:

Ap 0-21 cm: pardo escuro (7,5 YR 3/2 úmido); barro argiloso arenoso; moderada média e grande granular; firme, plástico e pegajoso; transição ondulada e clara.

$\mathrm{Bt}$

21-110 cm: vermelho amarelado (5YR 5/6 úmido); argila; moderada média prismática; friável, muito plástico e muito pegajoso; cerosidade moderada comum; transição ondulada e difusa.

$2 \mathrm{Bt}$

110-160 cm: vermelho (2,5 YR 4/6 úmido); argila; moderada grande prismática; friável, muito plástico e muito 
pegajoso; cerosidade abundante e forte; transição ondulada e difusa.

$\mathrm{BC} \quad 160-220 \mathrm{~cm}$ : vermelho (2,5 YR úmido); argila; fraca média e grandes blocos subangulares; muito friável, plástico e pegajoso.

Observações: Raízes finas abundantes até $110 \mathrm{~cm}$, poucas até $160 \mathrm{~cm}$.

Macroporos abundantes em todo o perfil.

Galerias biológicas $<3 \mathrm{~mm}$, comuns até o 2Bt2.

Linha de pedra constituída de seixos de quartzito irregulares de $1 \mathrm{~cm}$, até matacões de 10 a $15 \mathrm{~cm}$.

Seixos pequenos de quartzito, esparsos nos horizontes $2 \mathrm{Bt} 2$ e $\mathrm{BC}$. 


\begin{tabular}{|c|c|c|c|c|c|}
\hline \multirow{2}{*}{ HOR. } & SIMB. & $\mathbf{A}$ & Bt1 & $2 \mathrm{Bt2}$ & $\overline{\text { BC }}$ \\
\hline & PROF.(cm) & $0-21$ & $21-100$ & $100-160$ & $160-220$ \\
\hline $\begin{array}{l}\text { COM } \\
\text { POSI } \\
\text { ÇÃO }\end{array}$ & $\begin{array}{l}\% \text { AREIA } \\
\text { GROSSA }\end{array}$ & 30,1 & 19,3 & 16,7 & 17,0 \\
\hline $\begin{array}{l}\text { ÇAO } \\
\text { ORGA }\end{array}$ & $\begin{array}{c}\% \text { AREIA } \\
\text { FINA }\end{array}$ & 28,7 & 28,5 & 24,1 & 25,4 \\
\hline \multirow{3}{*}{$\begin{array}{c}\text { ORGA } \\
\text { NULO } \\
\text { MÉTRI } \\
\text { CA }\end{array}$} & $\%$ SILTE & 16,5 & 11,3 & 10,8 & 8,4 \\
\hline & $\%$ ARGILA & 24,7 & 40,9 & 48,4 & 49,2 \\
\hline & $\begin{array}{c}\% \text { ARGILA } \\
\left(\mathrm{H}_{2} \mathrm{O}\right)\end{array}$ & 15,7 & 11,6 & 1,1 & 2,8 \\
\hline \multicolumn{2}{|c|}{ GRAU DE FLOCULAÇÄO \% } & 36,4 & 71,6 & 97,7 & 94,3 \\
\hline \multirow[t]{2}{*}{$\mathrm{g} / \mathrm{cm}^{3}$} & $\begin{array}{l}\text { DENSIDADE } \\
\text { APARENTE }\end{array}$ & 1,1 & 1,3 & 1,2 & 1,3 \\
\hline & DENSIDADE REAL & 2,5 & 2,6 & 2,5 & 2,5 \\
\hline \multirow{2}{*}{$\begin{array}{c}\mathrm{pH} \\
1: 2,5\end{array}$} & $\left(\mathrm{H}_{2} \mathrm{O}\right)$ & 4,6 & 4,5 & 4,8 & 4,9 \\
\hline & $\mathrm{KCl}$ & 3,9 & 3,9 & 4,2 & 4,5 \\
\hline \multicolumn{2}{|c|}{ C. ORGANICO \% } & 2,05 & 1,08 & 0,49 & 0,47 \\
\hline \multicolumn{2}{|r|}{$\overline{\mathrm{ppm}}$} & 8,2 & 0,4 & 0,8 & 0,4 \\
\hline \multirow{3}{*}{$\begin{array}{c}\text { COM } \\
\text { PLEXO }\end{array}$} & $\mathrm{Ca}^{+1}$ & 0,91 & 0,12 & 0,06 & 1,00 \\
\hline & $\mathrm{Mg}^{+F}$ & 1,11 & 0,15 & 0,13 & 0,08 \\
\hline & $\mathrm{K}^{+}$ & 0,50 & 0,05 & 0,02 & 0,01 \\
\hline \multirow{2}{*}{$\begin{array}{c}\text { SOR } \\
\text { TIVO }\end{array}$} & $\mathrm{Na}^{+}$ & 0,07 & 0,02 & 0,02 & 0,02 \\
\hline & $\mathrm{S}$ & 2,59 & 0,34 & 0,28 & 1,10 \\
\hline \multirow{3}{*}{$\begin{array}{l}\mathrm{mE} / \\
100 \mathrm{~g}\end{array}$} & $\mathrm{Al}^{\mathrm{F+}}$ & 0,82 & 1,45 & 0,82 & 0,30 \\
\hline & $\mathrm{H}^{+}+\mathrm{Al}^{3+}$ & 5,80 & 4,70 & 2,77 & 2,02 \\
\hline & $\mathrm{T}$ & 8,39 & 5,04 & 3,00 & 3,12 \\
\hline \multicolumn{2}{|r|}{ SAT. BASES V $\%$} & 31 & 7 & $\overline{8}$ & 35 \\
\hline \multicolumn{2}{|r|}{ SAT. Al $\%$} & 24 & 81 & 78 & 21 \\
\hline \multicolumn{2}{|r|}{ POROSIDADE } & 56 & 50 & 52 & 48 \\
\hline
\end{tabular}




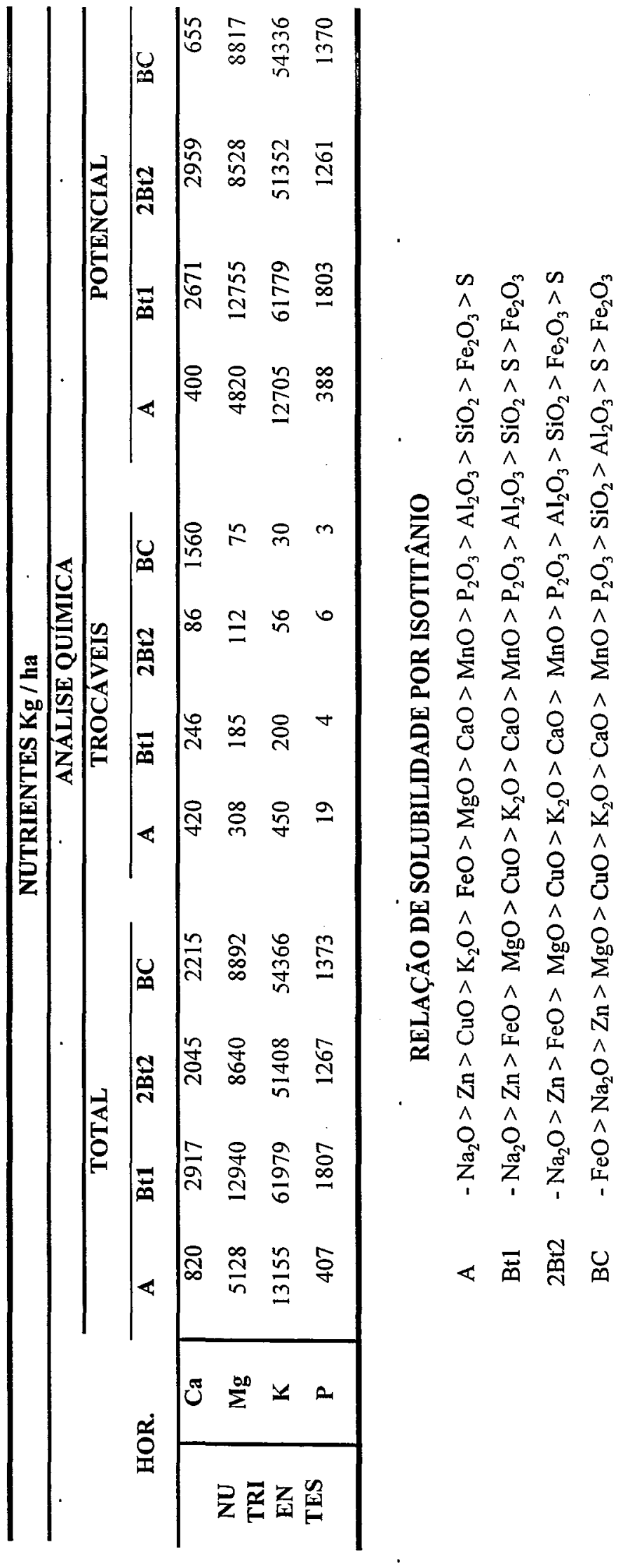


APÊNDICE 3 - Precipitação anual (mm) para as microbacias A e B.

Período: Junho de 1987 a maio de 1995.

\begin{tabular}{c|c}
\hline PERIODO & $\begin{array}{c}\text { Precipitação } \\
(\mathrm{mm})\end{array}$ \\
\hline Jun/87 - mai/88 & 1675,80 \\
\hline Jun/88 - mai/89 & 1043,50 \\
\hline Jun/89 - mai/90 & 1343,30 \\
\hline Jun/90 - mai/91 & 1634,20 \\
\hline Jun/91 - mai/92 & 1077,30 \\
\hline Jun/92 - mai/93 & 1362.20 \\
\hline Jun/93 - mai/94 & 1170,90 \\
\hline Jun/84 - mai/95 & 1310,90 \\
\hline Média Anual & 1327,26 \\
\hline
\end{tabular}


APÊNDICE 4 - Deflúvio (mm) para a microbacia A e B. Período: junho de 1987 a maio de 1995 .

\begin{tabular}{c|c|c}
\hline Período & \multicolumn{2}{|c}{ DEFLÚVIO } \\
& \multicolumn{2}{|c}{$(\mathrm{mm})$} \\
\hline \hline & Microbacia A & Microbacia B \\
\hline Jun87/mai88 & 264,27 & 430,26 \\
\hline Jun88/mai89 & 333,55 & 490,31 \\
\hline Jun90/mai90 & 153,24 & 199,16 \\
\hline Jun90/mai91 & 99,28 & 113,28 \\
\hline Jun91/mai92 & 133,36 & 82,08 \\
\hline Jun92/mai93 & 28,26 & 40,07 \\
\hline jun93/mai94 & 4,58 & 49,82 \\
\hline Jun94/mai95 & 114,40 & \\
\hline Média anual & 141,37 & 200,71 \\
\hline
\end{tabular}


APÊNDICE 5 - Média anual para os Parâmetros Físicos pH, alcalinidade, condutividade, cor e turbidez na precipitação(Prec.) e deflúvio das microbacias $\mathrm{A}(\mathrm{DFA})$ e $\mathrm{B}(\mathrm{DFB})$ para o período: junho de 1987 a maio de 1994.

\begin{tabular}{|c|c|c|c|c|c|c|c|}
\hline Mes & Local & $\overline{\mathrm{pH}}$ & $\begin{array}{l}\text { Alcal. } \\
(\mathrm{mg} / \mathrm{l})\end{array}$ & $\begin{array}{l}\begin{array}{l}\text { Condut } \\
\text { (umho) }\end{array} \\
\end{array}$ & $\begin{array}{c}\text { Cor } \\
(\mathrm{ptCo})\end{array}$ & $\begin{array}{l}\text { Turb. } \\
\text { (FTU) }\end{array}$ & $\begin{array}{c}\text { Sed } \\
(\mathrm{mg} / \mathrm{l})\end{array}$ \\
\hline \multirow{3}{*}{ Jun. } & Prec. & 5.3 & 1.3 & 31 & 6 & 1.9 & \\
\hline & DFA & 6.0 & 12.2 & 67 & 70 & 5.9 & 12.6 \\
\hline & DFB & 6.1 & 10.7 & 66 & 36 & 4.2 & 11.2 \\
\hline \multirow{3}{*}{ Jul } & Prec. & 5.6 & 3.4 & 50 & 13 & 1.9 & \\
\hline & DFA & 6.2 & 12.8 & 77 & 62 & 4.7 & 9.7 \\
\hline & DFB & 6.2 & 10.5 & 67 & 30 & 3.3 & 9.8 \\
\hline \multirow{3}{*}{ Ago. } & Prec. & 5.9 & 4.5 & 51 & 9 & 2.0 & \\
\hline & DFA & 6.2 & 13.3 & 75 & 53 & 6.2 & 9.4 \\
\hline & DFB & 5.5 & 11.3 & 68 & 29 & 3.6 & 6.9 \\
\hline \multirow{3}{*}{ Set. } & Prec. & 5.4 & 2.2 & 42 & 6 & 1.4 & \\
\hline & DFA & 6.2 & 15.8 & 74 & 72 & 6.2 & 7.5 \\
\hline & DFB & 6.2 & 12.5 & 66 & 35 & 4.0 & 7.8 \\
\hline \multirow{3}{*}{ Out. } & Prec. & 5.3 & 2.0 & 41 & 10 & 1.3 & \\
\hline & DFA & 6.0 & 14.6 & 77 & 68 & 5.5 & 13.8 \\
\hline & DFB & 6.1 & 12.0 & 72 & 34 & 4.7 & 14.0 \\
\hline \multirow{3}{*}{ Nov. } & Prec. & 5.3 & 2.2 & 44 & 4 & 2.0 & \\
\hline & DFA & 6.0 & 15.3 & 83 & 71 & 7.8 & 13.3 \\
\hline & DFB & 6.1 & 12.1 & 73 & 39 & 4.6 & 11.3 \\
\hline \multirow{3}{*}{ Dez. } & Prec. & 5.4 & 2.5 & 46 & 7 & 1.5 & \\
\hline & DFA & 6.2 & 14.7 & 87 & 88 & 7.2 & 13.9 \\
\hline & DFB & 6.2 & 11.9 & 78 & 41 & 5.2 & 11.2 \\
\hline \multirow{3}{*}{ Jan. } & Prec. & 5.5 & 2.3 & 42 & 5 & 1.7 & \\
\hline & DFA & 6.2 & 14.9 & 91 & 98 & 8.8 & 18.8 \\
\hline & DFB & 6.2 & 11.8 & 78 & 47 & 7.7 & 14.6 \\
\hline \multirow{3}{*}{ Fev. } & Prec. & 5.2 & 1.9 & 41 & 5 & 1.8 & \\
\hline & DFA & 6.2 & 14.6 & 96 & 127 & 10.0 & 20.6 \\
\hline & DFB & 6.2 & 11.7 & 79 & 53 & 7.4 & 13.8 \\
\hline \multirow{3}{*}{ Mar. } & Prec. & 5.4 & 2.7 & 39 & 4 & 1.3 & \\
\hline & DFA & 6.1 & 16.7 & 85 & 107 & 8.3 & 14.5 \\
\hline & DFB & 6.2 & 12.2 & 77 & 41 & 6.0 & 15.4 \\
\hline \multirow{3}{*}{ Abr. } & Prec. & 5.3 & 2.9 & 40 & 5 & 2.2 & \\
\hline & DFA & 6.1 & 13.0 & 75 & 95 & 7.6 & 11.1 \\
\hline & DFB & 6.2 & 11.2 & 76 & 58 & 5.0 & 12.0 \\
\hline \multirow{3}{*}{ Mai. } & Prec. & 5.2 & 1.7 & 38 & 9 & 2.2 & \\
\hline & DFA & 6.0 & 12.2 & 75 & 91 & 6.9 & 11.9 \\
\hline & DFB & 6.2 & 11.0 & 77 & 50 & 5.6 & 11.0 \\
\hline \multirow{3}{*}{ Média Anual } & Prec. & 5.4 & 2.5 & 42 & 7 & 1.8 & \\
\hline & DFA & 6.1 & 14.2 & 80 & 84 & 7.1 & 13.1 \\
\hline & DFB & 6.1 & 11.6 & 73 & 41 & 5.1 & 11.6 \\
\hline
\end{tabular}


APÊNDICE 6 - Média anual para os Parâmetros Físicos pH, alcalinidade, condutividade, cor e turbidez na precipitação(Prec.) e deflúvio das microbacias A(DFA) e B(DFB) para o período: junho de 1994 a maio de 1995.

\begin{tabular}{|llcrrrrr|}
\hline Mes & Local & pH & $\begin{array}{c}\text { Alcal. } \\
\text { (mg/l) }\end{array}$ & $\begin{array}{c}\text { Condut } \\
\text { (umho) }\end{array}$ & $\begin{array}{c}\text { Cor } \\
\text { (ptCo) }\end{array}$ & $\begin{array}{c}\text { Turb. } \\
\text { (FTU) }\end{array}$ & $\begin{array}{c}\text { Sed } \\
(\mathrm{mg} / \mathrm{l})\end{array}$ \\
\hline \hline & Prec. & 5.2 & 0.5 & 68 & 25 & 4.3 & \\
Jun. & DFA & 6.0 & 8.4 & 109 & 138 & 7.8 & 14.9 \\
\hline & Prec. & 5.5 & 1.8 & 71 & 5 & 6.8 & \\
Jul & DFA & 6.0 & 9.3 & 99 & 50 & 4.4 & \\
\hline & Prec. & & & & & & \\
Ago. & DFA & 6.3 & 26.5 & 110 & 50 & 5.4 & \\
\hline & Prec. & & & & & & \\
Set. & DFA & 6.3 & 10.1 & 96 & 98 & 11.7 & \\
\hline & Prec. & 5.6 & 5.4 & & 90 & 37.5 & \\
Out. & DFA & 6.4 & 9.6 & 103 & 163 & 18.8 & \\
\hline & Prec. & 5.5 & 3.4 & 75 & 17 & 19.9 & \\
Nov. & DFA & 6.1 & 9.8 & 137 & 94 & 8.7 & 19.9 \\
\hline & Prec. & 5.5 & 3.1 & 53 & 13 & 1.9 & \\
Dez. & DFA & 6.1 & 9.4 & 130 & 125 & 8.6 & 24.2 \\
\hline & Prec. & 4.7 & 0.7 & 76 & 16 & 1.6 & \\
Jan. & DFA & 6.1 & 13.6 & 153 & 265 & 8.6 & 48.8 \\
\hline & Prec. & 4.4 & 0.3 & 48 & 10 & 1.2 & \\
Fev. & DFA & 5.4 & 8.8 & 123 & 217 & 8.2 & 33.6 \\
\hline & Prec. & 5.0 & 0.3 & 61 & 18 & 1.6 & \\
Mar. & DFA & 6.1 & 13.4 & 111 & 194 & 7.5 & $\mathbf{3 1 . 1}$ \\
\hline & Prec. & 5.1 & 0.5 & 59 & 8 & 1.5 & \\
Abr. & DFA & 6.0 & 11.4 & 101 & 180 & 12.3 & 18.2 \\
\hline & Prec. & 4.9 & 0.5 & 48 & 7 & 2.0 & \\
Mai. & DFA & 5.9 & 10.3 & 94 & 142 & 10.1 & 15.7 \\
\hline & Prec. & 5.1 & 1.7 & 62 & 21 & 7.8 & \\
Média Anual & DFA & 6.1 & 11.7 & 114 & 143 & 9.3 & 25.8 \\
\hline & & & & & & & \\
\hline
\end{tabular}

